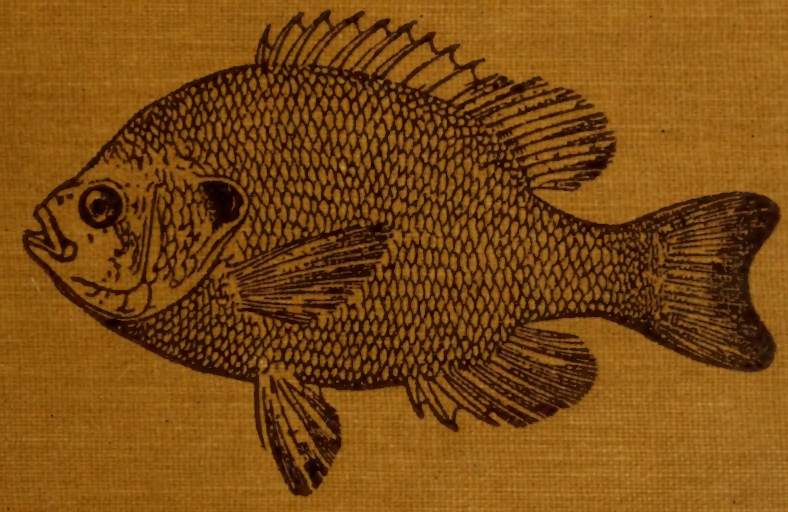




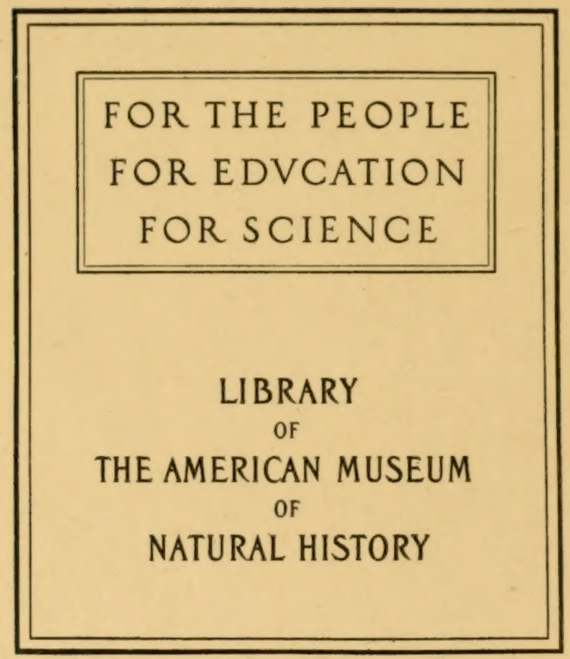







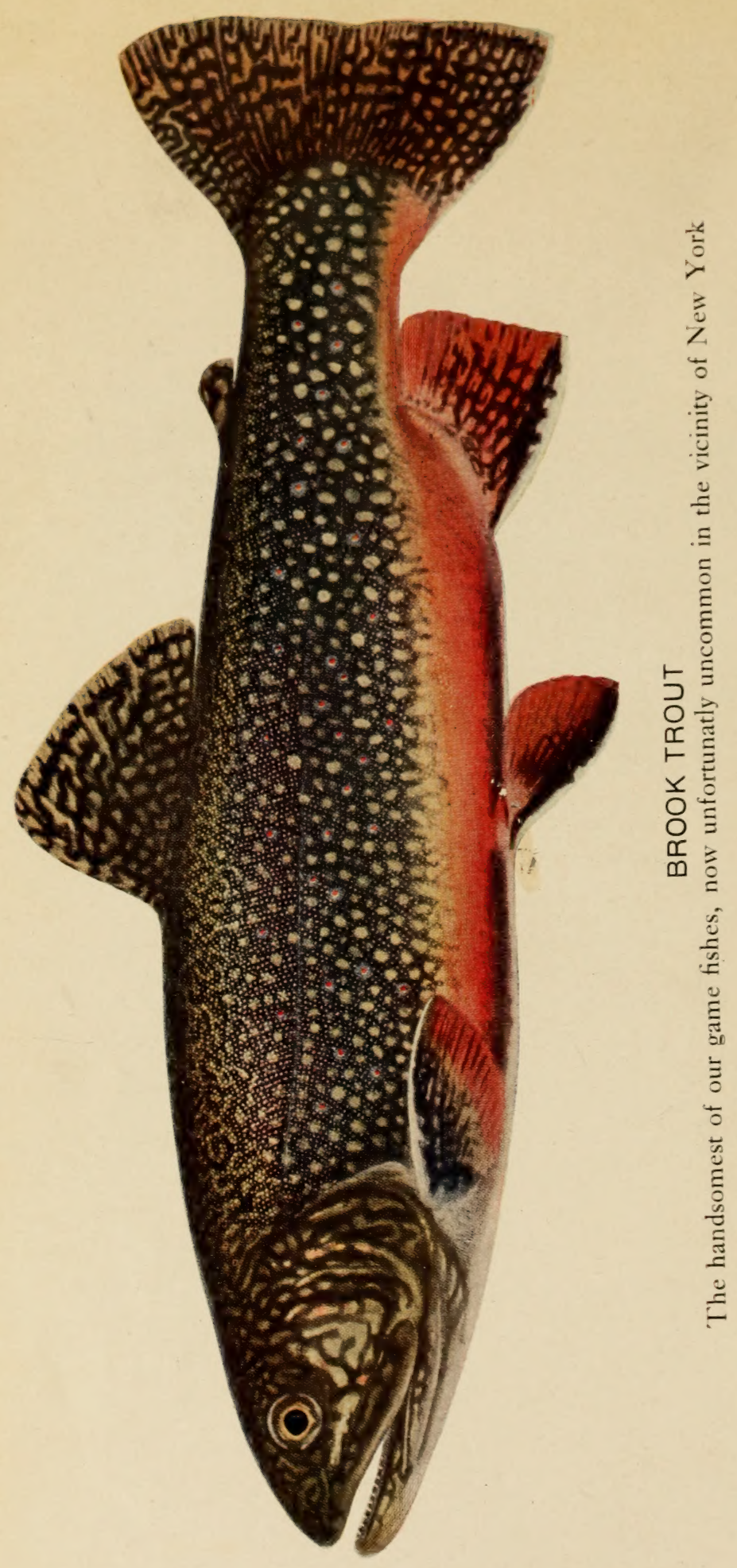




\title{
FISHES OF THE VICINITY OF NEW YORK CITY
}

\author{
By John Treadwell Nichols \\ With an Introduction \\ By William K. Gregory
}

The American Museum of Natural History HANDBOOK SERIES No. 7

NEW YORK, 1918

PRINTED AT THE MUSEUM 
"Science consists of human experience, tested and placed in order. The science of ichthyology represents our knowledge of fishes, derived from varied experiences of man, tested by methods or instruments of precision and arranged in orderly sequence. This science, in common with every other, is the work of many persons, each in his own field, and each contributing a series of facts, or series of tests of the alleged facts of others, or some improvement in the method of arrangement."

Jordan; introductory remarks to the History of Ichthyology, being chapter twenty-two of a Guide to the Study of Fishes. 


\section{PREFACE}

It is doubtful if the angler stops to reflect that the fish he is landing - or hopes to land-is by way of being a very distant relative. The chances are that he is quite ignorant of the fact, or, if aware of it, he has other and more important business in hand. He may, however, like to know the name of some strange fish that he catches, or possibly may wonder wherein a fish differs from other animals, and-what is a fish anyhow? There are many others who are interested in fish and who would like to know something about those to be found here or hereabouts, and how to set about finding out the name of any unusual fish. So Mr. Nichols has written at some length of the fishes found in this vicinity, has given a complete list of those that have been taken in the waters from Rockaway even to Yonkers, and has provided a key to the puzzle of their names. And Doctor Gregory has told of the characters that distinguish a fish from other backboned creatures and of the curious adaptations of structure that have enabled fishes to live in the water for millions of years past.

These articles, by the courtesy of the United States National Museum, are supplemented by a number of reduced copies of some of the figures of fishes prepared in 1883 for the Fishery Industries of the United States, and later used in Jordan and Evermann's Fishes of North and Middle America. These were models of their kind and for accuracy of detail have never been excelled.

On account of the size of the illustrations this volume has been issued in leaflet form though listed as No. 7 in the Handbook series.

New York, August 15, 1918.

F. A. LuCAS. 


\section{CONTENTS}

Introduction by William K. Gregory

The Structure and Mechanism of Fishes

I. How to Study Fishes Systematically Aspects of the Study of Fishes................. 18

How to Describe and Identify a Fish ............... 19

The Classification of Fishes. . . . . . . . . . . . . . 22

II. A Review of the Kinds of Local Fishes. . . . . . . . . . . . 33

III. A List of the Fishes Known to Have Occurred Within Fifty 



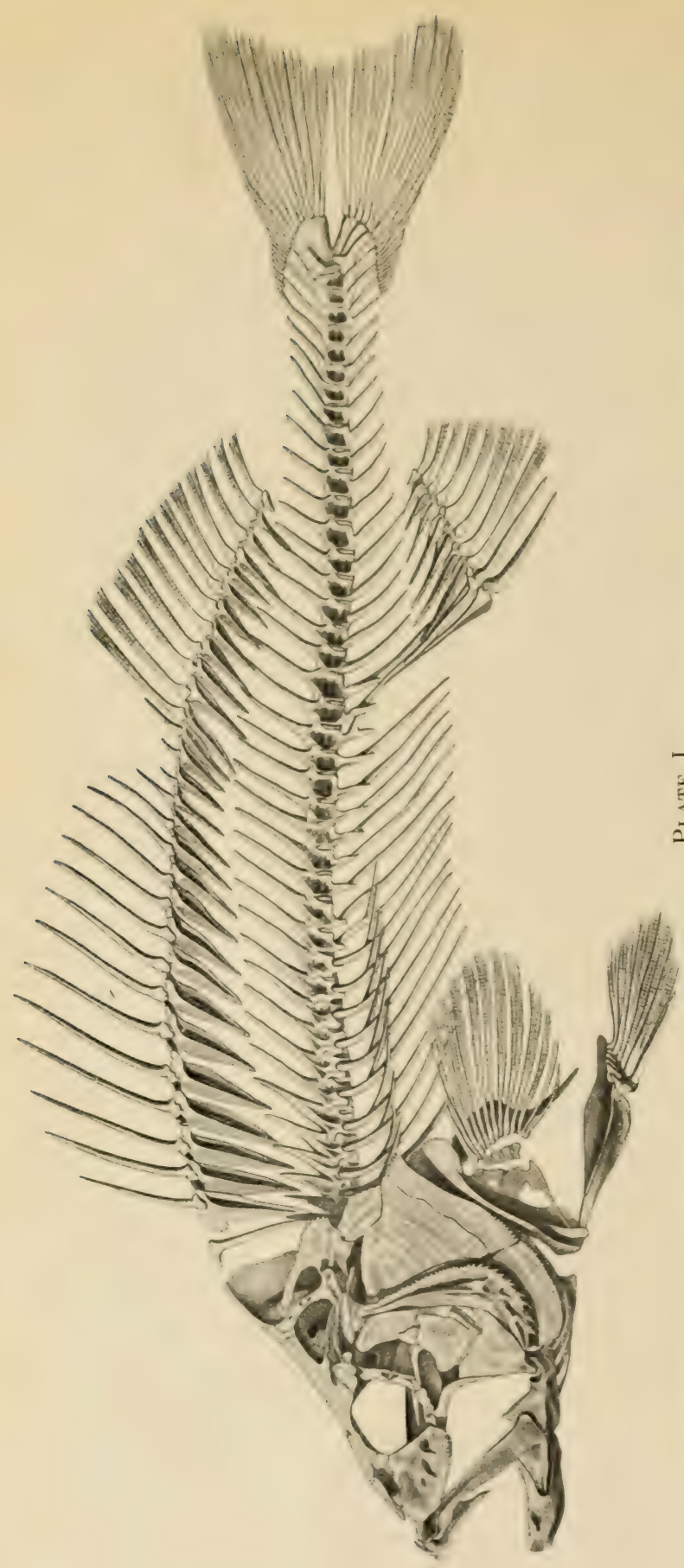

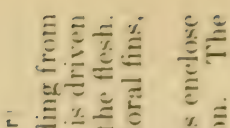

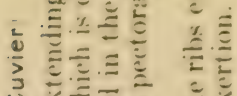

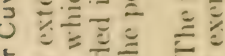

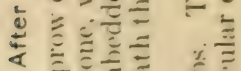

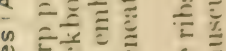

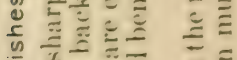

$=-\bar{a}$

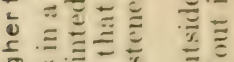

क

政

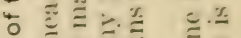

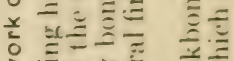

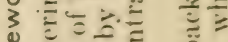

E

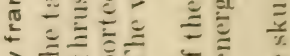

入

을

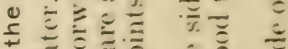

-

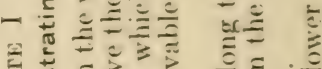

E⿱

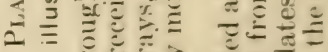

$\div$

-

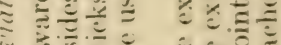

今

政

¿

을

I

0,

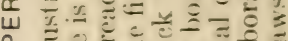

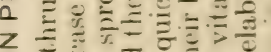

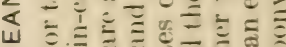

일

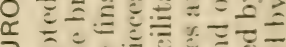

山

㟧

$z=0$

을

山

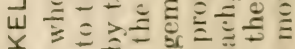

क

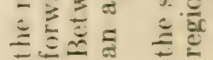




\title{
INTRODUCTION
}

\section{The Structure and Mechanism of Fishes}

\author{
By William K. Gregory
}

"When we no longer look at an oryanic being as a sauge looks at a ship, as something wholly beyond his com prehension; when we regard every production of nature as one which has had a long history; when we contemplate every complex structure and instinct as the summing up of many contrivances, each useful to the possessor, in the same way as any great mechanical invention is the summing up of the labor, the experience, the reason, and even the blunders of numerous workmen; when we thus view each organic being, how far more interesting - I speak from experience-does the study of natural history become!"

Charles Darwin

If Darwin's savage could see a U-boat rise to the surface, turn around, submerge and rapidly move away, he would probably think that the thing was alive and call it a great fish. He would certainly not realize as we do that a submarine is only a complicated machine. On the other hand when we look at a fish moving in the water, we are apt to think of it only as a living thing and we scarcely realize that it is also a mechanism, which although very complicated in its details is not difficult to understand in its main principles. We have become accustomed to the thoughts that our own bodies are living machines which take in fuel in the form of food, that we consume this fuel in a certain long, winding chemical laboratory called the digestive system; and that we use part of the energy derived from the food in moving from place to place. Exactly as in ourselves the fish derives its motive power from the slow combustion, or oxidation, of the fuel that it takes in as food; but in the fish the necessary oxygen for consuming the food is extracted from the water by the gills which thus serve the purpose of our lungs.

In both fish and man the many-jointed backbone supports the body and head. The fish, however, drives the body forward in a horizontal position, while man carries his backbone vertically, standing on end as it were, upon the legs, which are outgrowths of the body. In fishes the legs are represented by the muscular and bony bases of the ventral fins (see Plate 1), while their pectoral fins correspond to our arms.

In both cases the body is propelled by muscles, which in the fish take the form of rows of zigzag segments separated by thin membranes and arranged along the sides of the body, while in man these primary muscular elements are fused and combined into a complex system of muscles for moving the limbs.

In normal fishes the more or less fan-shaped tail is the chief propelling organ. It is attached to the backbone by $\mathrm{V}$-shaped plates of bone which grow downward from the lower side of the backbone (Fig 1). 


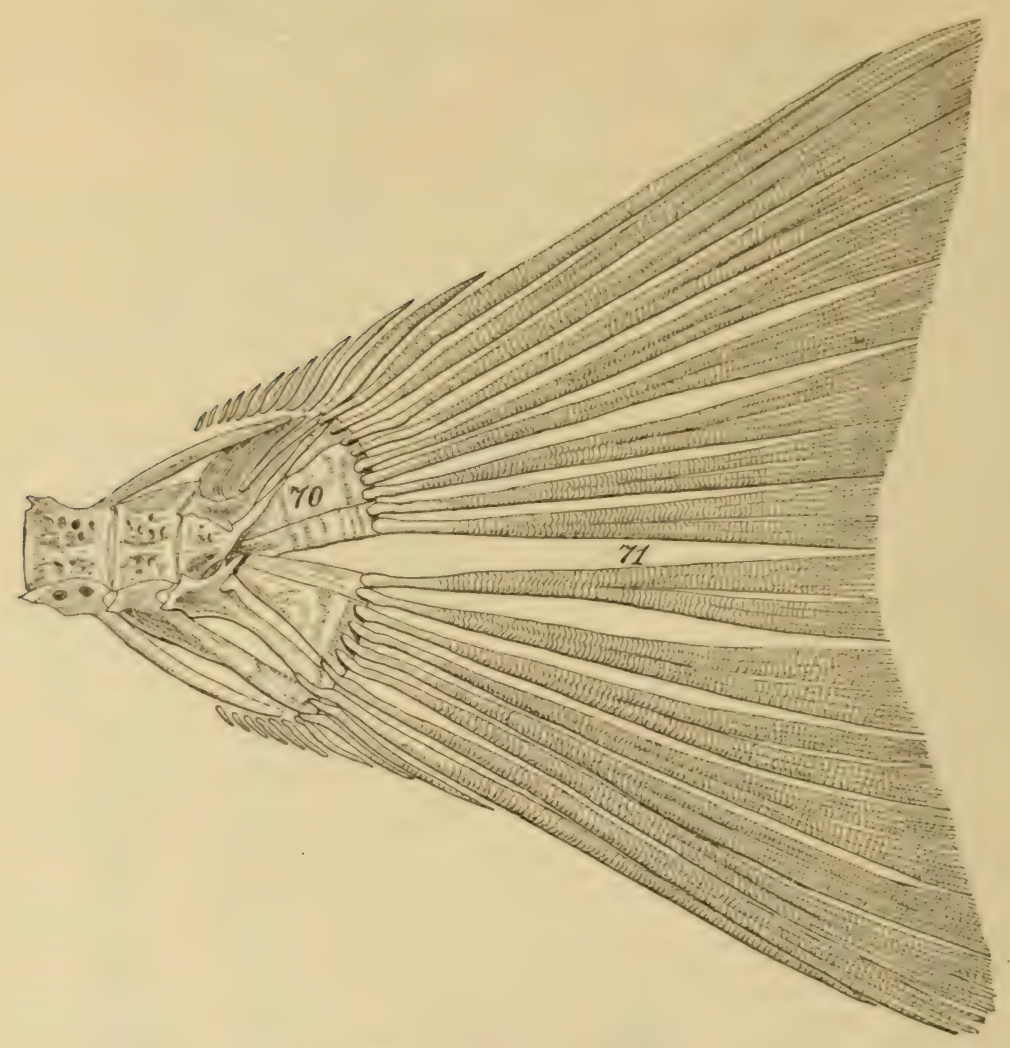

Fig. 1. BONY FRAMEWORK OF TAIL-FIN OF STRIPED BASS. See page 5 70 Hypural bones, supporting the tail; 71 bony fin rays of tail.

Drawing by F. A. Lucas

The fins of fishes were originally hump-like projections from the body, involving the $\mathrm{V}$-shaped muscle segments and covered with a weblike fold of skin bearing small bony scales. During the course of long ages some of the bony scales on the fins became arranged in rows end to end, and running from the margin of the fin toward its base. These small rows of scales then fused together into jointed rods and so gave rise to the bony fin-rays upon which the web is stretched. At first (that is, in the most ancient fossil "ganoid" fishes and even in the modern gar pike) the scale-like origin of all the fin rays is very evident, but in the course of time the first few rays of the back fin (Plate I) in many - fishes lost their jointed character and the outer ends became narrowed down to a sharp point, this process culminating among the so-called 
spiny finned fishes (Acanthopteri) such as the Bass and Perch, in which the spiny rays are conspieuously developed. The fin rays are supported by small bony rods embedded in the flesh. The fin rays can be erected like the mast of a canoe by the action of muscles at the base of the fin, and if the front fin ray becomes very large, several of the supporting rods below the rays may fuse together to afford a firmer base.

By quickly erecting the fins a fish can suddenly check its forward motion. On the other hand in darting forward the back fins are lowered and the side fins pressed against the body. The back fins also act as keels to prevent the body from slipping sideways through the water. The spines in the fins serve to stiffen them and are also of protective value. The pectoral and ventral fins are used chiefly to steer the fish up and down and in turning to right or left, and also to steady the fish when resting; sometimes, especially in slow-swimming or deep-bodied fishes, the pectoral fins propel the body forward, the tail acting more as a rudder.

Normal types of fish have a compressed spindle-shaped body provided with a wide tail fin, but many types become excessively long, with very numerous joints in the backbone; these have more or less reduced tail fins and move through the water by wriggling as do eels.

In the sharks, which are on the whole the most primitive of existing fishes, the whole body including the head is covered with a tough skin, thickly studded with small points, or granules. These often take the form of thorns and they are composed chiefly of a substance resembling the dentine of teeth covered with a thin enamel-like layer, so that it may be said that a shark has little teeth all over his skin, which are identical in structure with the larger teeth inside the mouth.

In the higher fishes the teeth are confined to the jaws, to the roof and base of the mouth, and to the skin that covers the gill arches in the throat.

In the oldest ganoid fishes and in the modern gar pike the head and body are encased in hard, more or less shiny, armor. This is formed in the deeper layers of the skin by bony plates, which are covered with a shiny enamel-like layer called ganoine.

The armor covering the head is not continuous but is divided up into separate and distinct bony plates connected either by movable joints or by contact surfaces called sutures. The armor on the body in primitive fishes is composed of oblique rows of close-set diamondshape scales connected with each other by peg-and-socket joints, as in the gar pike. Later these scales begin to overlap each other, the back- 
warlly projecting part being at first "cycloid" in shape and finally developing a row of points or bristles on the free edge ("ctenoid" type). The scales originally were faced with a thin shiny layer of "ganoine" but most fishes have lost all traces of this layer and their scales have become horny in texture. Sometimes the scales become reduced and disappear or are replaced by bony plates, as in the Sturgeon.

The reason for the marked difference between the body armor (seales) and the bony plates on the head is that, with few exceptions, the body must remain flexible for swimming, while the upper part of the head must be rigid, like the bow of a ship.

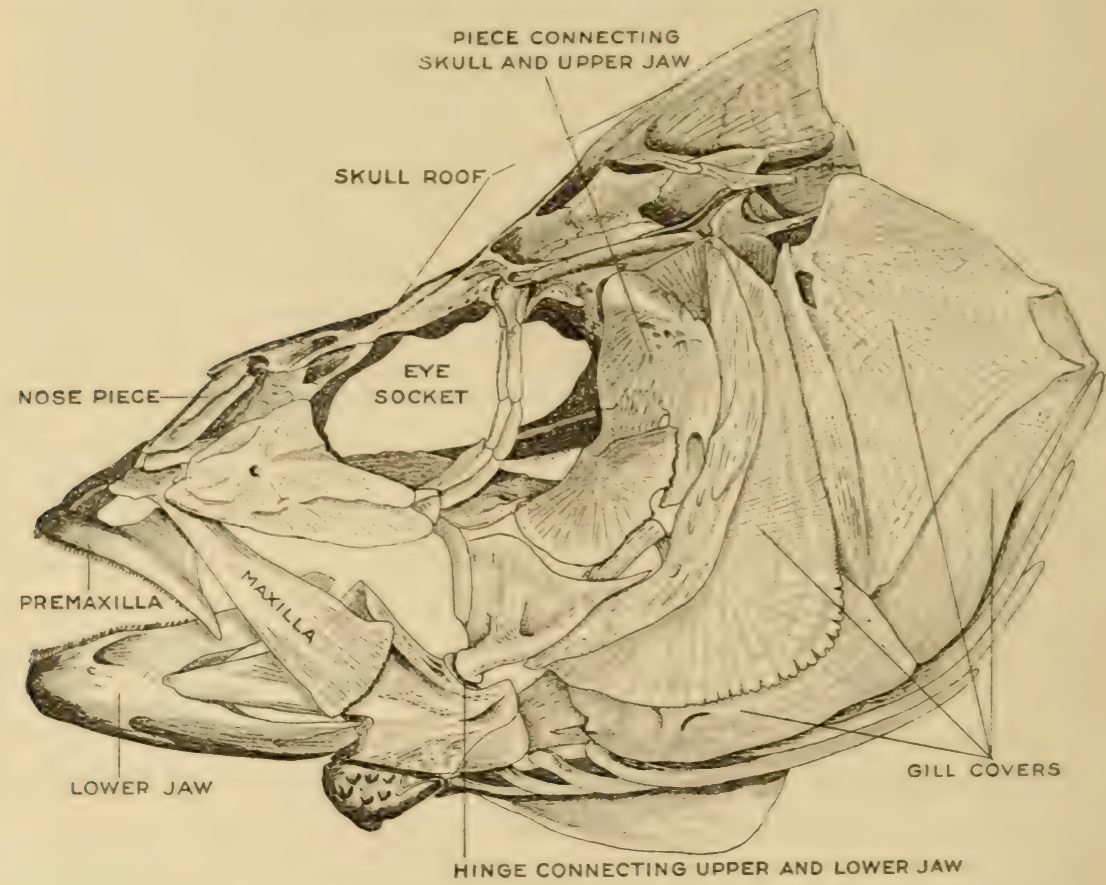

Fig. 2. SKULL OF STRIPED BASS.

Drawing by F. A. Lucas

The head of a fish (Fig. 2) is composed of very numerous and complex parts which work together like the parts of an ingenious mechanism. The head is first of all a structure for supporting and protecting the highly sensitive organs, by means of which the animal is guided toward its food. These sense organs, which represent our nose, eyes, ears and organs of balance, are arranged in pairs on either 


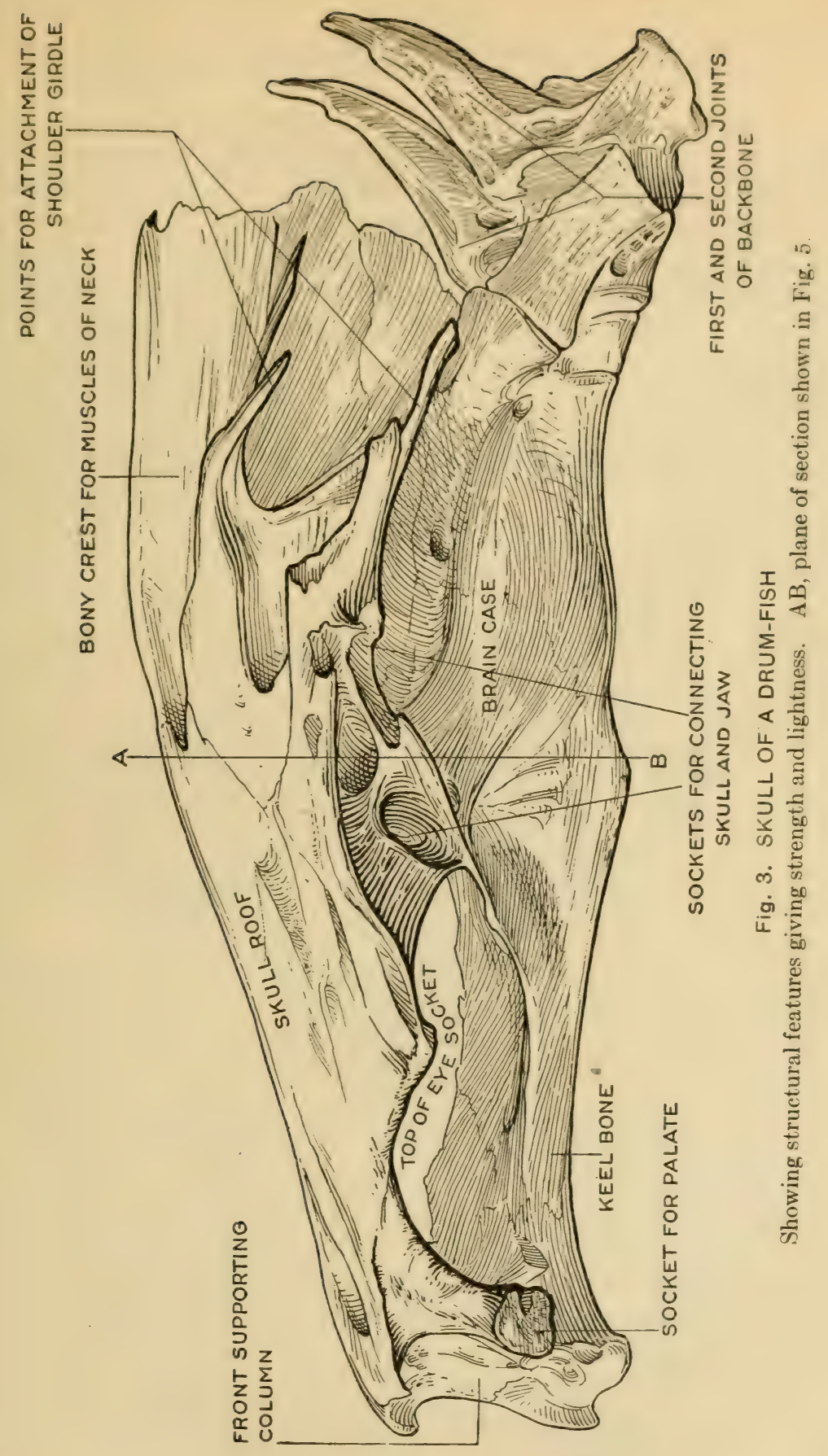


side of the mid-line, in the order given. The sense organs communicate by nerves with the "central" or brain, where the signals received from the sense organs are sorted out; and from whence new or induced nerve currents are sent out to the machinery of the body. Sense organs, brain and connecting nerves are all inclosed in strong bony capsules and troughs which make up the inner skull, or endocranium. The roof of this structure is formed by the bony skull plates above described, and it is strongly braced below by a sort of keel called the parasphenoid bone (Fig. 3). At the rear the inner skull is securely joined to the backbone. The skull must of necessity be strongly built in order to resist the thrust of the backbone, as the body is driven

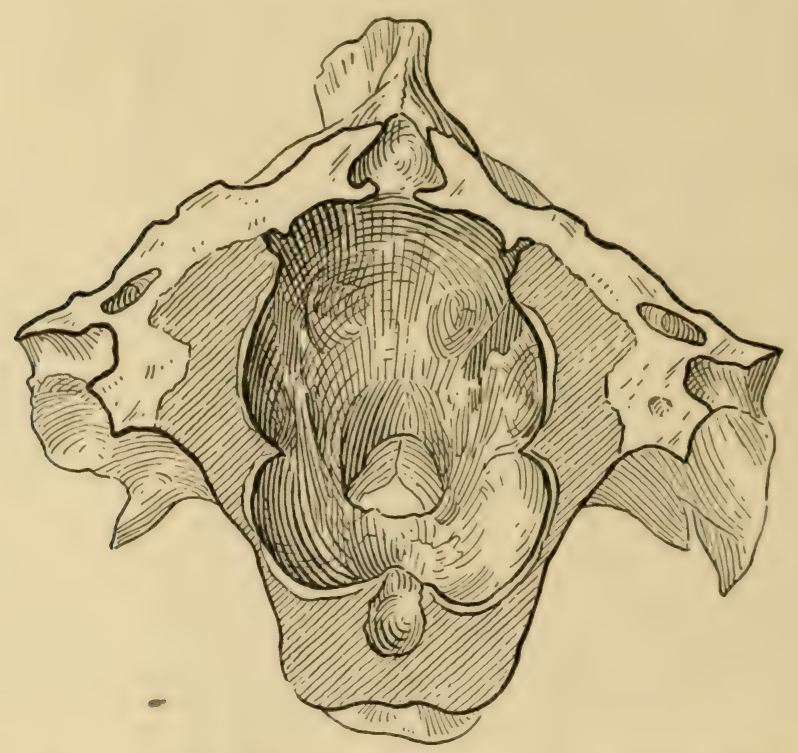

Fig. 4. CROSS SECTION OF SKULL OF DRUM-FISH

Showing inner skull (cross-hatched) and roof of brain-case (white).

forward through the water. In primitive fishes the inner skull and the outer skull are fairly distinct and the outer plates may be stripped off after boiling or macerating the skull; but in the higher fishes, such as the bass, the outer skull plates sink beneath the skin and become welded with the inner skull (Fig 4).

From this stiff and immovable part of the head is suspended a complex apparatus, by means of which the food is seized and water $\mathrm{i}=$ taken into the throat to pass over the gills and out through the g:!l 
slits. In order to understand this jaw-gill-arch complex we must go back to the more primitive fishe;, especially the sharks, in which we find that the gill-slits in the side of the throat are supported by a jointed framework of gristly, or eartilaginous, rols and connecting pieces arranged as in Fig. 5. Several rows of attached muscle slips arranged in circulas and oblique series cause the alternate expansion and contraction of this framework, so that the water is pumped into the throat and

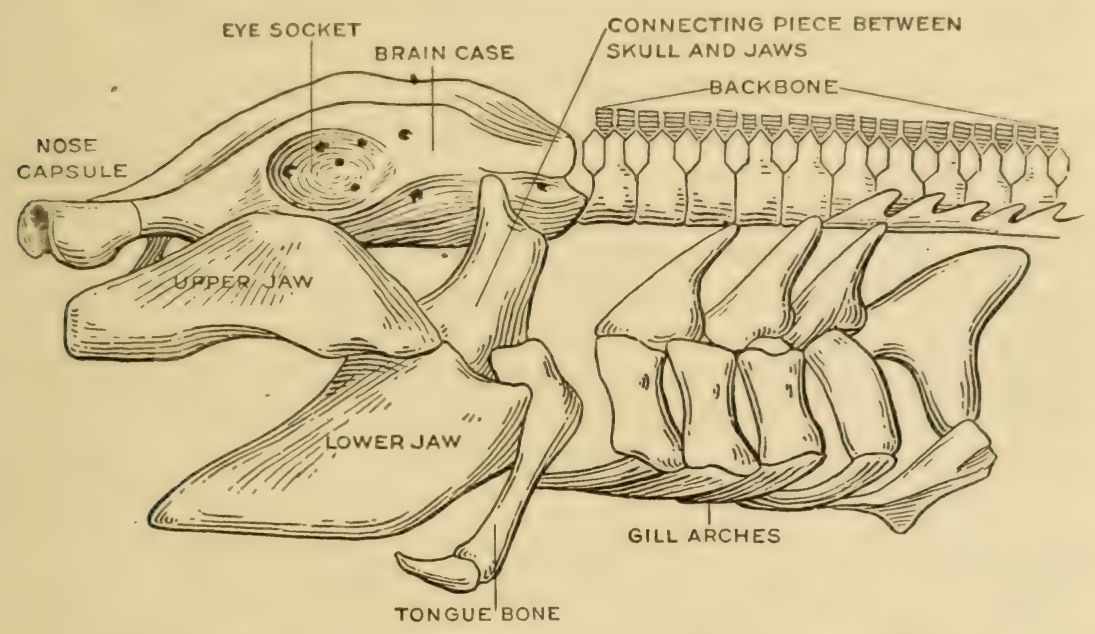

Fig. 5. SKULL AND ATTACHED PARTS OF A SMALL SHARK

(From Jordan, after Parker and Haswell).

ejected through the gill-slits. In typical sharks each of the five gill-slits opens freely on the side of the head, but in all the higher fishes such as the bass these side slits are covered on the outside by a large bony and fleshy flap called the operculum (Fig. 2) which opens to the rear and is hinged in front to the back part of the upper jaw. By means of suitable muscles the opercular flap can be alternately opened or closed, so that it acts as an escape valve for the water in the gill chamber. In some cases, as in the Moray, the opercular flap becomes pouch-like and leathery and acts like a rubber pump, or syringe.

The gills themselves consist of extremely numerous long plaits of thin membrane, which offer in a small space a large exposure to the oxygen-bearing water. The oxygen gas passes freely through the membrane and is taken up by the blood in the very minute tubes of the gills. This blood comes from the body where its supply of oxygen had been exhausted. It is pumped to the gills by the heart, entering the lower part 
of the gills; after passing through the minute tubes and renewing its supply of oxygen, it leaves the gills on the upper side and is collected into a central pipe ealled the dorsal aorta, from which in turn it is distributed to the body, where it is again deprived of its oxygen and sent back to the gills. In most fishes the circulation of the blood is comparatively sluggish and the body temperature is low, but in some very active types, such as the tunny, the process of oxidation and the circulation of the blood are quickened and the body temperature is greatly raised.

The jaws of sharks, which are still in a primitive condition, consist of two pairs of bars underneath the head, one pair forming the upper jaw and another the lower jaw. These bars consist of gristle, or cartilage, stiffened by the deposition of calcium carbonate ${ }^{1}$. The jaws of sharks agree with the gill bars behind them in their minute structure, in their relations with the throat cavity and nerves and to a certain extent even in general appearance. It is highly probable that the jaws originally served to support a pair of gills, that they were in fact true gill-arches and shared in the opening and closing movements of the gill-arch framework; in the course of long ages, as the animals came to pursue larger prey, the gill-arch-jaws became larger, and finally were used exclusively for snapping at the prey, which was also held fast by the thorny skin around the mouth. The jaw muscles of sharks are very simple, being wrapped around the back part of the upper and lower jaws and serving to squeeze the jaws together. These jaw muscles are comparable with the muscles behind them that work the gill-arches.

The jaws of ordinary sharks are attached to the under side of the skull by ligament and to the back of the skull by a cartilaginous bar, called the hyomandibular, which represents the upper part of an old gill-arch. Between the hyomandibular and the skull and behind the eye there is a small opening, called the spiracle, which was formerly a gill-cleft but is greatly reduced or even absent in most fishes; in the skates, however, it serves chiefly as an intake valve for water for the gill chamber.

The jaws of typical fishes such as the bass are much more complicated than those of sharks and have been evolved from the more primitive conditions described above. The primary, or cartilaginous, upper jaws become saturated with bone cells, which deposit phosphate of lime and thus form true bony upper jaws; meanwhile the skin of the lips has produced bony plates which form a secondary, or false, upper

\footnotetext{
There are no bone cells in any part of the skeleton of sharks and Rays. Hence the name "Cartilage Fishes" (Chondrichthyes) often applied to this group.
} 
jaw which lies on the surface outside of the primary upper jaw. This secondary upper jaw is composed on each side of two pieces, called the premaxilla and maxilla; these at first form a single curved piece which together with its fellow of the opposite side forms a $\Lambda$ shaped arch above the mouth. Gradually, however, the front piece (premaxilla) grows downward in front of the second piece (maxilla) and finally excludes it from the margin of the mouth. Meanwhile the maxilla develops a movable joint on the front part of the skull; finally it acts as a lever or handle for the premaxilla and is attached to the lower jaw in such a way that when the lower jaw is lowered the maxilla is pulled downward and the premaxilla is pushed forward. It is by means of this arrangement that many fishes such as carps and bass can suddenly shoot out their secondary upper jaw, or bony lips.

The secondary lower jaw consists of bony plates in the skin around the primary lower jaw, which these plates ensheath, both inside and outside the mouth, but not at the back part. The joint of the lower jaw is still formed from the back part of the primary upper and lower jaws. The skin on the roof of the mouth also gives rise to bony plates which form a bony palate and unite more or less closely with the underlying primary upper jaw.

The primary, or internal, upper jaw of higher fishes is attached in front to the lower part of the skull and in the rear through the enlarged hyomandibular bone very much as it was in the sharks, but it receives much additional support and bracing from the front part of the gill-cover. The whole jaw-gill apparatus is movably jointed so that the food can be engulfed and swallowed. On the inside of the upper joints of the gillarches in the back of the throat are a pair of clusters of teeth. Similar clusters of teeth are developed in the floor of the throat, supported by the lower parts of the gill-arches. These teeth, called "pharyngeal teeth," assist either in pushing the food down into the stomach or in crushing the food in the throat. Numerous forms of throat teeth occur in different fishes. In the carps they take the form of finger-like projections; in the drums, the cunners, parrot fish and others, the lower throat teeth become consolidated into stout crushing masses.

The pectoral fins of sharks are supported by a stout arch of cartilage called the primary pectoral girdle. In typical fishes bony plates in the skin become attached to the primary pectoral girdle and greatly strengthen it. This secondary, or outer, girdle is connected above with the back of the skull; it curves around tine back of the gill-cover and runs forward on the lower surface of the throat behind the lower segments of the gill- 


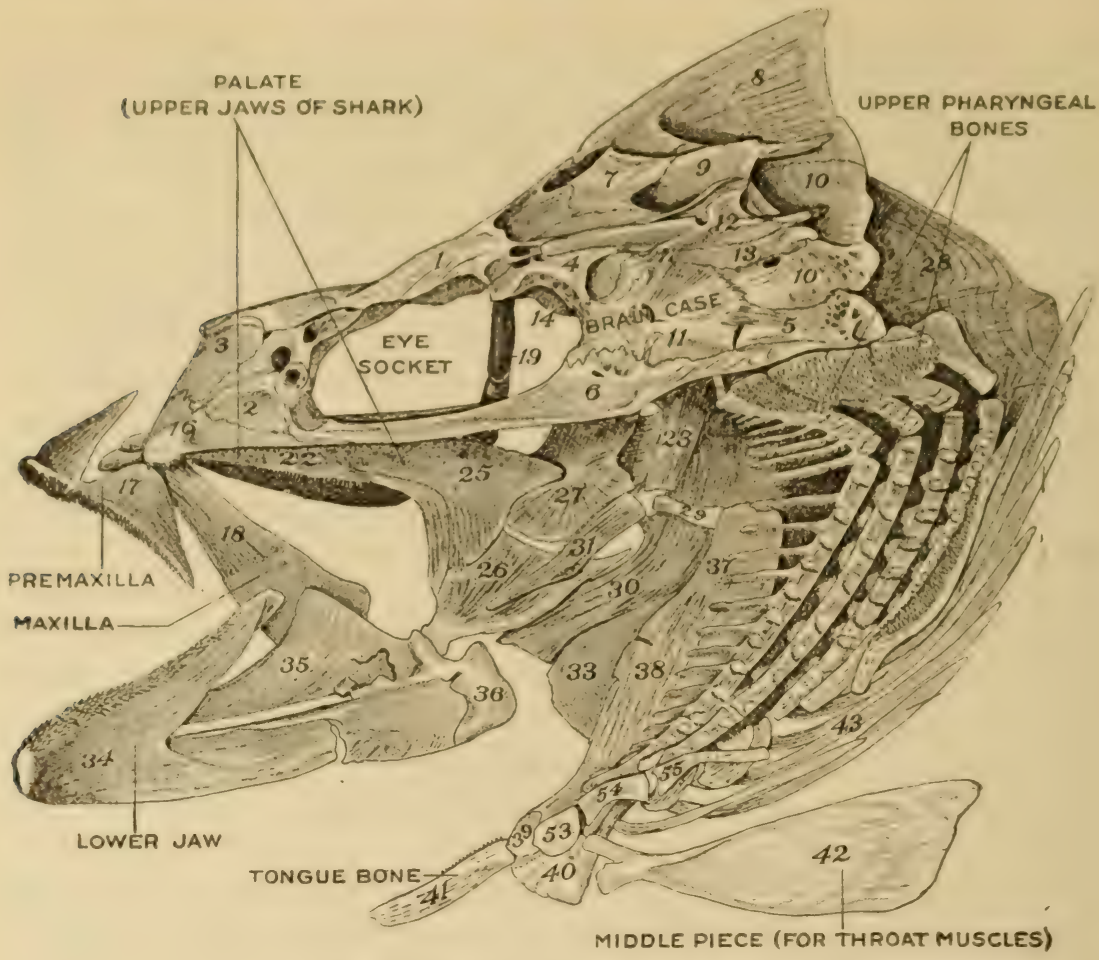

Fig. 6. SKULL OF STRIPED BASS

Longitudinal section. Drawing by F. A. Lucas

\section{BONES OF THE SKULL}
1. Frontal
2. Prefrontal.
3. Ethmoid-Nasal of Huxley.
4. Postfrontal.
5. Basioccipital.
6. Parasphenoid.
7. Parietal.
8. Supraoccipital.
9. Epiotic.
10. Exoccipital.
11. Prootic.
12. Pterotic.
13. Opisthotic.
14. Alisphenoid.
15. Not shown.
16. Vomer.
17. Premaxillary.

18. Maxillary.

19. Suborbitals.

20. Nasal (Marked Nose-piece in Fig. 2).

21. Not shown.

22. Palatine.

23. Hyomandibular.

24. Ectopterygoid.

25. Entopterygoid.

26. Quadrate.

27. Mesopterygoid.

28. Operculum.

29. Interhyal.

30. Preoperculum.

31. Symplectic.

32. Suboperculum.

33. Interoperculum. 
34. Dentary.

35. Articular

36. Angular.

37. Epihyal.

38. Ceratohyal.

39. Basihyal.

40. Basihyal.

41. Glossohyal.

42. Urohyal.

43. Branchiostegal Rays.

53. First Basibranchial.
54. Second Basibranchial.

55. Third Basibranchial.

56. Hypobranchial.

57. Hypobranchial.

58. Ceratobranchial.

59. Pharyngobranchial.

60. Not shown.

61. Epibranchial.

62. Pharyngobranchials.

63. Gillrakers.

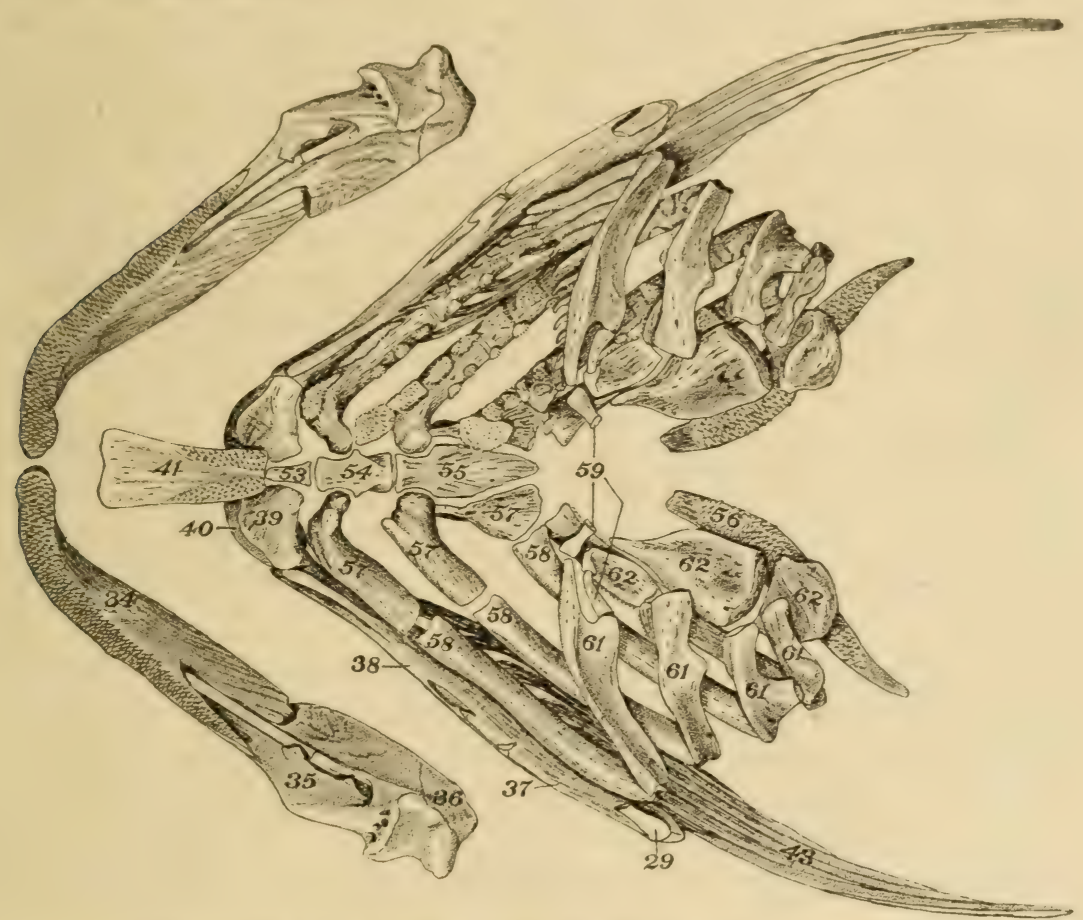

Fig. 7. LOWER JAW AND BONY FRAMEWORK OF GILL ARCHES OF STRIPED BASS, SEEN FROM ABOVE

Drawing by F. A. Lucas

arches. As it is thus closely connected with the solid skull as well as with stout gill-arches, it forms a firm base for the pectoral fins.

The ventral fins of sharks rest upon a cartilage base, called the pelvis, consisting of short rods of cartilage which afterward became fused into a V-shaped mass. In typical fishes this structure, called the pelvis, has become bony and in the higher fishes it has shifted forward, 
bearing the ventral fins with it until it acquires a firm attachment to the under side of the pectoral arch. In other words the hind limbs of a bass are fastened to the under side of his collar bones. This arrangement greatly facilitates the quick turning and steering of the fish, and fishes of this improved type now far outnumber all others.

Fish are enabled to rise or sink at will in the water by means of a swim bladder. Originally this was probably a kind of pouch on the side of the gullet, and may perhaps have served to secrete some fluid of use in digestion. In many primitive fishes (lung fishes, ganoids) the "swim bladder" has become richly supplied with blood vessels and assists in the process of oxidizing the blood. In the higher fishes, however, it loses the blood vessels and becomes tough and elastic in structure; it also loses its connection with the gullet and forms a closed bag filled with gases from the body of the fish. By some means that is not yet well understood the fish is able either to compress the air bladder and thus squeeze his body into a smaller space thus decreasing his bulk and causing the body to sink in the water, or, by relaxing the air bladder and extending the sides of the body, the fish can increase his bulk and rise in the water.

The necessity of free motion through a dense yet unstable medium has held the evolution of the fish's body-form to compact and conventional lines. Similarly the buoyancy of water has made supporting structures (as limbs) unnecessary, and by neutralizing gravity, done away with need for lightness.

Theoretically there is no limit to the size of a fish since its weight is supported by the water. Practically, however, the difficulty of moving through a dense medium and the still more practical difficulty of getting enough to eat seem to impose pretty definite limits on the size of fishes, and just as the little rodents - rats and mice - are the most numerous of land mammals so the smaller fishes are the commonest denizens of the deep.

In an earlier geological epoch there were fishes as big as whales, but these huge sharks died out and it is not at all improbable that they died because they could not get enough to eat.

In conclusion we have seen that in many ways a fish resembles a self-directing, self-propelled torpedo, and if space were available we might point out other curious and interesting features of this kind: how the eyes are turned about in their sockets, how the inner ear includes delicate instruments for indicating the position of the body and for keep- 
ing it upright, how some forms are provided with powerful searchlights for illuminating the dark depths in which they live. But, verbum sat sapient $i$, let us investigate these things for ourselves.

Turning now to a consideration of fishes as living creatures rather than as machines it is interesting to note that sharks, which have a very simple body structure with practically no improvement since an early period in the earth's history, have reached a very high plane in the evolution of reproduction. While modern fishes usually lay a great many small eggs which are fertilized by chance in the water, this casual method of reproduction means much wastage, as many of the eggs are lost or consumed by predaceous animals, and the young, when hatched, are small and comparatively helpless. In most sharks, on the other hand, the eggs hatch and the young reach an advanced stage of development within the body cavity of the mother, and in some there are complicated mechanisms for their nourishment before birth, comparable with the condition found in mammals. In the few species which still lay eggs, these are large and protected by a leathery egg-case. It would seem that by specialization in the one matter of reproduction, and the consequent elimination of a great deal of waste, the sharks living at the present time are able to compete successfully with other fishes, which are more modern and better adapted to their environment in many other ways. 


\section{FISHES OF THE VICINITY OF NEW YORK}

AND OUR KNOWLEDGE OF THEM-CLASSIFIED AND REVISED

By J. T. Nichols

\section{How To Study Fishes Systematically}

\section{Aspects of the Study of Fishes}

Ichthyology, or the scientific study of fishes, like that of any other group of animals, may be roughly divided into three aspects, Systematic, Economic and Philosophic.

Systematic Ichthyology deals with defining, naming and classifying fishes. It is a very necessary preliminary to every other branch of the subject, without which our knowledge would fall into the utmost confusion. The most satisfactory system which has been devised for assigning technical names to fishes (as indeed to all animals and plants), and the one universally followed, is to combine two names, the first or generic name shared by the kinds most closely related, the second or specific name diagnostic of the one which bears it. The generic name is always spelled with a capital, the specific name with a small letter.

Economic Ichthyology is the study of fishes in relation to human welfare, and its most important branch naturally is concerned with their use as frod-fisheries, fish-culture, etc. Few persons realize on what a large scale fish-culture, fish-farming it might be called, is carried on. In the year ending June 30, 1917, the United States Bureau of Fisheries distributed roughly three hundred nineteen millions of fish eggs and four thousand seven hundred thirty millions of young fishes to be planted in various waters.

Philosophic Ichthyology concerns itself with the fish and its place in nature, the broadest and purest aspect of the science. It follows the evolution of fishes by the evidence of fossil records from early periods in the earth's history to the many specialized forms of the present day. It examines the wonderful correlations existing between the habits and structures of fishes. In fact its possibilities and ramifications are without limit.

The series of vertebrate (back-boned) animals from fishes to man is characterized by an increasingly complicated structure, an increasingly complicated environment for the individual to react to, and an increasingly complicated mentality. Fishes doubtless possess the simplest, lowest type of vertebrate mind. A great deal of their behavior can be explained as reflex action, a definite stimulus followed by a definite 
response. The bass sees a glittering minnow and strikes at it. An artificial minnow affects him similarly and he reacts towards it in the same way. One of the most complicated mental phenomena the writer has observed in fishes was illustrated by two Porgies in a tank at the New York Aquarium. One of these had a bullying attitude, the other one a cringing attitude. From time to time the former would dart in the direction of the latter, which would slink away in evident alarm. Though the difference of size between the two was insignificant, clearly the former was ruling the tank, and they both knew it, that is, each one was adjusted mentally to reply to stimuli in a way appropriate to the role he was playing. A parallel human situation would be associated with definite emotional states of mind, whence we may argue that the fish is capable of such.

\section{How to Describe and Identify a Fish}

The first problem which faces the student of fishes is to differentiate between the many species. The sea is large, and thousands of distinct species of fishes find a place in it. Fresh waters, especially those of the cold or temperate north, harbor a comparatively small number. The species vary in every conceivable particular from the minute structure of their bone and the form of the internal organs to the proportions of the body or the number of rays in the fins. A few simple characters and proportions are customarily used in comparative descriptions of fishes, and it is necessary to master these before a specimen can be properly identified, that is, assigned to the name by which it is known in literature. All measurements are taken in a straight line, as with a pair of dividers. A fish's length is by custom the distance from the tip of the snout to the base of its tail fin. Its depth is the greatest vertical distance from the upper to the lower contour of the body, exclusive of fins. The length of the head is measured from the tip of the snout to the most posterior point on the border of the gill-cover exclusive of spines which may project still further backward. The eye measurement is the greatest diameter of same. The maxillary measure is taken from the tip of the snout to the posterior end of the maxillary, or movable bone in the side of the upper jaw. The interorbital is the least distance between the eyes across the top of the head. The snout is measured from its tip to the front of the eye. These absolute measurements are of little value, as a fish's size is not fixed (unlike the size of a bird, for instance, which is constant within a few millimeters for a given species), and a given species of fish may vary considerably in size, even when full-grown, 
dependent on the waters it inhabits, the amount of food it has had available, and other factors. It is the proportions between the different measurements that are fairly constant within a given species, and which are relied upon for making diagnoses. The larger measurements, as the length of the head and depth of the body, are stated according to the number of times they are contained in the length of the fish, and similarly the smaller measurements, as that of the eye and maxillary, according to the number of times they are contained in the head. The fish's anterior paired fins are known as the pectoral fins. They may be placed on the lower surface, on the side behind the head, or at the throat. The posterior paired fins are the ventral fins. A median fin behind these is the anal fin. One, two or more fins in the mid-line of the back are known respectively, beginning with the anterior one, as the first, second and third dorsal fins. The fin at the end of the tail (which may be pointed, rounded, square or forked in outline, and is occasionally unsymmetrical) is the caudal fin. The number of supporting rays in a particular fin are important in the diagnosis of a fish, as their number is constant within narrow limits of variation, in any one species, just as a normal man has five fingers and toes, no more, no less. These rays may be divided into two classes. First, spines, solid, rigid and sharp-pointed. Second, soft rays, more or less split or branched terminally, jointed and flexible. It is customary to distinguish between the two by using Roman numerals for the spines. Dorsal X, 14 means a dorsal fin with ten spines followed by fourteen soft rays. Dorsal X-14 would mean two entirely separate dorsal fins, the first of spines, the second of soft rays. The lateral line of a fish is a series of pores or markings, usually one on a scale, beginning at the shoulder and ending at the base of the caudal fin. It may be straight or variously curved, complete (if it covers the entire distance) or incomplete, and is sometimes duplicated, or broken in the middle, or lacking altogether. The number of scales, in inverse ratio to their size, is written thus: 5-32-8, which signifies five horizontal rows between the lateral line and base of first dorsal fin, thirty-two more or less obliquely vertical rows crossing the lateral line, and eight horizontal rows between the lateral line and anal fin, or the scales may be counted from lateral line to ventral fin, and so stated.

There is a regrettable lack of good popular books which will be of service to the amateur in identifying fishes. Almost the only comprehensive work, the "Fishes of North and Middle America" by Jordan and Evermann, in four volumes, is too technical and bulky. A comparatively small number of species of fishes occur in one locality. It is hoped that 


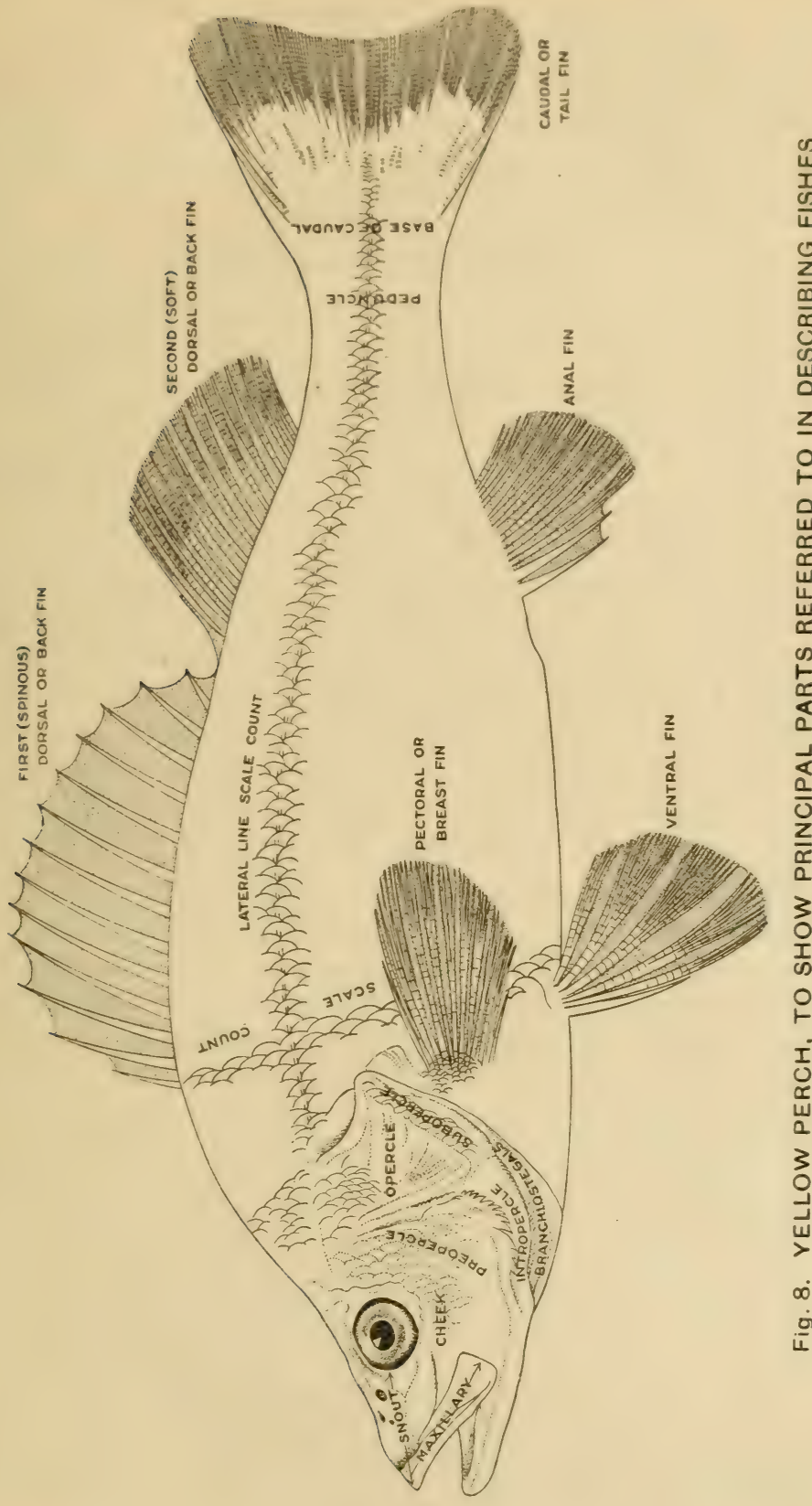


the narrative survey which follows, of those found near New York City, will enable the average fisherman to correctly name such as may come into his hands, besides giving an idea of the various kinds which inhabit our waters. Those kinds which resemble one another have been grouped together, and there are figures of one or more fishes in each group, which will form a basis for comparison with the others.

\section{The Classification of Fishes}

The dominant type of modern fish resembles a Perch or Bass. It has a large mouth, short body, and spines in the fins, particularly in the back fin (which either has the anterior part made up of spines or else is divided into two separate fins, the first of which is spiny).

Probably the majority of species which exist today, in fresh and salt water taken together, are of this type. In attempting to sort out or classify the remaining species, we can make out first, a more or less complete series of forms from the most primitive fish, the Shark, leading up to the Perch type, and secondly, several divergent lines of development leading away from it into still more highly specialized or more or less degenerate series. In reviewing the local species of fishes, it has been impossible always to group them so as to bring out their true relationship; in fact the grouping attempted is a compromise between this and an attempt to group them in a convenient manner for reference. The Lampreys, which are taken up with the Eels (Section IV), have little relationship with any of our other fishes. Many students claim that they are not in the true sense of the word fish at all. The Sharks and Rays (I) stand somewhat less apart from the remaining species, all of which differ from them in having the cartilaginous structures more or less replaced by bone, and all of which may be placed in the comprehensive group known as Teleostomi. The Ganoid fishes (II) stand apart as being more cartilaginous than other Teleostomi, all of which belong in the major group known as Teleostei. There is a rather evident connection between the Ganoid fishes and the Herring and Trout group (IV), and the true Eels (V) seem to be degenerate derivatives from the Herring, Trout group. Just where the Catfish, Carp group (III) should come in is open to question. We follow the conventional treatment in placing them below the Herrings and Trouts, though very probably it will be proved that they are really more recent than these. Between these primitive fishes and the forms which begin to approach the Perch, the line of ascent is obscure and broken, though the Pike (VI) and a variety of specialized forms (VII) doubtless belong to this section of it. 
The so-called Acanthopteri are spiny rayed fishes including the dominant Perch, Bass group (IX and $\mathrm{X}$ ), and all those forms with clearly traceable relationships to it; as the Mullets, etc. (VIII) related to its probable immediate ancestors (indeed these ancestors may well have been very much like the Pirate Pereh); or the derivative Mackerel-like fishes (XI) (an adaptation to wide ranging habit over open seas). Another clearly marked line (XII) is through the Angelfish (beginning with the Wrasses, which, superficially at least, are more Perch-like than the Mackerels, ending with the very un-Perch-like plectognath fishes, which might be considered the apex of specialization in fish life). The Sculpin-like or mail-cheeked fishes (XIII), although a well marked group, have certain members of sufficiently Perch-like character to show their derivation. The Gobies, Blennies, etc. (XIV) are probably one or several lines unrelated to this one, although it is conceivable that they arose through more or less Sculpin-like forms. At the other end of this series there is an approach to the Codfishes (XV). Recent investigation and recently discovered fossils have shown that the very remarkable Flatfishes (XVI) were derived rather directly from Perch-like fishes. The final section, the Frog Fishes (XVII) would seem to have been evolved from Perch-like ancestors, either directly or through Sculpin, Blenny or Goby-like forms.

The following artificial key to the families of our fishes (based only on those species which occur locally) may be found useful by the student.

I. A round sucking terminal mouth with concentric rows of teeth. Body eel-like.

Petromyzonidae

II. Mouth transverse on the lower surface of head. Skin of body continuous over the fins. Scales spine or nodule-like, usually minute, sometimes absent.

- 1. Not notably flattened horizontally, tail fin unsymmetrical, the upper lobe the longer.

A. Head peculiar, broad, flat, hammer-shaped. Sphyrnidae

B. Upper lobe of tail excessively long. Alopiidœ

C. A spine at the front of each of the two back fins.

Squalidee

D. Not as above.

a. Peduncle usually without a keel on the side. Tail fin notably unsymmetrical, not lunate. 
(I) Teeth narrow, sharp, white, with small cusps at their bases. Two back fins of about equal size.

Carchariida

(II) Teeth not as above. Second back fin usually small.

Galeida

b. Peduncle with keel on its side. Tail fin less unsymmetrical, more or less lunate.

(I) Teeth large.

Lamnidae

(II) Teeth small, gill slits very wide, crossing practically the entire breadth of the neck. Cetorhinida

2. Body moderately flattened. Head circular, somewhat constricted at the neck. Mouth almost terminal.

Squatinida

3. Body notably flattened, no demarcation between it and the pectoral fins with which it is confluent at the sides to form a disk; neck region not constricted.

A. Disk squarish with one corner at the snout. Tail elongate, moderately stout. Spines and prickles scattered on body and tail. Rajidae

B. Disk rounded, without spines or prickles. Tail fin squarish, rather broad. Narcobatida

C. Disk more or less rounded at the sides, sometimes with a few spines. Tail long or short, usually lash-like, usually with a single large serrate spine at its base. Head not elevated.

Dasyatida

D. Disk pointed at the sides. The head elevated and squarish. Tail lash-like and moderately long.

Myliobatida

1II. Front of head elongate beak-like, sometimes only one of the jaws elongate.

1. Both jaws elongate, bearing strong teeth.

A. Scales large, plate-like, regular (fresh water). Lepisosteida 
B. Scales very small, thin, inconspicuous. Belonide

2. Snout elongate, forming a hard bony sword, or a spear-like process, without teeth.

A. Snout a very long, hard, horizontally flattened
Xiphiidae
sword.
B. Snout cylindrical and spear-like. Dorsal fin
very long and high.
Istiophoridoe.
C. Snout moderately elongate, a hard pointed pro-
cess, mouth small, transverse below it. Body
flattened, more or less triangular in form.
Ogcocephalidae

3. Lower jaw elongate, spear-like without teeth. Hemiramphida

4. Mouth small, at the end of the long snout.

A. Bony and segmented, tail fin fan-shaped or absent, size small.

Syngnathida

B. Not bony and segmented. Tail fin forked, with a central lash. Size large.

Fistulariidre

IV. Not as above.

1. Body elongate, eel shaped or band shaped.

A. No well marked tail fin. Back fin continuous with the anal fin around the tail.

a. No ventral fins. Anguilla and Leptocephalidce

b. Ventral fins reduced each to a forked barbel, placed under the mouth.

Ophidiida

B. Anal fin extending upward around the tail, but separate from the higher back fin. Zoarcidae

C. A well marked rounded tail fin more or less continuous with the back fin above and the anal fin below. Rays of the back fin spine-like.

a. Head large squarish, the eyes placed high and far forward, the mouth large, opening upward.

Cryptacanthodida

b. Head not squarish, compressed like the body, small.

Blenniida (Pholis)

D. Tail fin forked. Body band-like, silvery. Jaws without teeth.

Ammodytidoe. 
E. Tail finless, thread-like. Body band-like, silvery. Jaws with large teeth. Trichiurides

2. Body elongate, not eel shaped. Back fin long and high, the rays all flexible spines, mouth with large canine teeth.

Anarichadida

3. Body elongate, tapering, slender, covered with bony plates.

Agonida

4. Body flattened, to lie on the bottom. Both eyes on one side, the other side colorless.

A. A pectoral fin on the colored side. Pleuronectida

B. No pectoral fin on the colored side. Mouth small and very crooked.

Soleida

5. Not as above.

A. Mouth small. The teeth more or less fused and nipper-like.

a. Body triangular, beech-nut shaped, encased in a hard shell.

Ostraciida

b. Body rotund, covered with stout spines.

Diodontida

c. Body rotund, more or less finely prickly, skin loose. Capable of swelling to a spherical form when irritated. Tetraodontidae

d. Body deep and vertically flattened. Skin leathery.

(I) First back fin of three spines, scales evident.

Balistidae

(II) First back fin of a single spine, scales not evident.

Monacanthidre

(III) No spines. Back and anal fins high. flipper-like. The body ending immediately behind them. A large offshore fish.

Molida

B. A sucking disk on the top of the head or on the breast.

a. Sucking disk on the top of the head. Echineidida 
b. Sucking disk on breast. Rotund, scaleless with rows of hard nodules. Cyclopteridae

C. Not as above.

a. A single back fin, entirely of soft rays or with one initial spine, sometimes a second small adipose fin, ventral fins present.

(I) Shark-shaped. Upper lobe of tail fin the longer. Mouth on under side of head, snout rather long, pointed. No scales, but rows of rough plates of different sizes.

Acipenserida

(II) Lower lobe of forked tail fin the longer. Pectoral fins very large, used as support in gliding flight through the air.

Exocœtidee

(III) Tail fin not notably unsymmetrical.

(1) A small adipose fin on the posterior part of the back.

(A) Mouth surrounded with barbels, body scaleless. Back and breast fins with a stout initial spine.

Silurida

(B) No barbels, body covered with small scales.

(a) Ventral fins about under the back fin. Mouth moderately large.

$\mathrm{x}$. Scales very small scärcely evident.

Salmonidoe

y. Scales larger, about 68 in a lengthwise series. A small silverysided fish.

Argentinidae

(b) Ventral fins before the back fin. Mouth very large. Color mottled. Marine.

(2) No adipose back fin.

Synodontidae

(A) Teeth in the mouth small or absent.

(a) No teeth in the small or moderate sized mouth.

Lower pharyngeal bones with one or more rows of teeth. Tail fin usually moderately forked. Strictly fresh-water species.

x. A small, thick-lipped, sucking mouth, opening downward. Pharyngeal teeth in a single comb-like row. Catostomidoe 
y. Mouth not as above. Pharyngeal teeth few, in one or more rows. Cyprinider

(b) Mouth with or without small teeth. Tail fin strongly forked, almost all marine or anodromous.

x. Mouth moderate or large, jaws equal or the lower the longer.

(x) Lateral line present. Elopidu

(y) Lateral line absent. Clupeida

y. Snout projecting more or less beyond the mouth.

(x) Mouth very large. Engraulidida

(y) Mouth small. Body cylindrical. Marine.

Albulida

(z) Mouth small. Body deep and compressed. Fresh water.

Dorosomida

(c) Mouth with small teeth. Tail fin squarish or rounded. Small fishes of fresh, brackish, or salt water.

x. No groove across the snout behind the top of the upper jaw.

Umbridae

y. A groove across the snout behind the top of the upper jaw.

Poeciliidur

(B) Mouth large, with large teeth. Tail fin moderately forked, back fin placed far back. Esocida

b. No ventral fins. Small silvery deep bodied, compressed marine fishes, back and anal fins long and similar in form, of soft rays. Tail fin deeply forked.

Stromateida

c. Some of the anterior rays of the back fin spiny, or an anterior spiny back fin, or several isolated spines in front of the back fin.

(I) Numerous thread-like filaments before the pectoral fin. Polynemidae

(II) A long double barbel at the chin. Mullidie 
(III) Several finlets between the back and anal fins and the forked tail fin.

Scombridar

(IV) Back fin high, of flexible spines, running the entire length of the back. Form tapering, tail fin deeply forked. Coryphanidne

(V) A bony stay across the cheek and strong spines about the large head; or entire head encased in a bony armature.

(1) Head not encased in a bony armature.

(A) Ventral fins with the normal spine followed by - five soft rays. Body covered by small scales.

Scorponidoe

(B) Ventral fins with less than five soft rays. Body without true scales.

Cottida

(2) Head encased in a bony armature. Breast fin large.

(A) Three fleshy tentacles before the breast fin.

Triglida

(B) No fleshy tentacles before the breast fin. Breast fin very large.

Cephalacanthidae

(VI) Head squarish. Eyes on top of head, far forward. Mouth opening upward.

Uranoscopida

(VII) Head and mouth very large. Body tadpole-shaped. Teeth large and pointed. Two or three slender isolated spines on the top of the head with flaps at their tips. Size large.

Lophiidae

(VIII) Body and fins very irregular in outline, everywhere with small flap-like processes. The breast fins with stalked bases, arm-like. Small fishes hiding in weed. Antennariidae

(IX) Not as above.

(1) Isolated spines in front of the back fin.

(A) Tail fin rounded. Ventral fins composed principally of a strong spine. Very small fishes of fresh, brackish and salt water. Gasterosteidae

(B) Tail fin rather forked. Isolated spines on the back short.

(a) Tail fin very deeply forked.

Carangidoe 
(b) Tail fin moderately forked. Elongate, head pointed, lower jaw projecting. Striped lengthwise in color.

Rachycentrido

(c) Tail fin weakly forked. Head blunt and rounded, color dark. Stromateida

(2) Spiny-rayed back fin separate from the soft-rayed fin behind it.

(A) Ventral fins placed decidedly behind the breast fins. Tail fin forked.

(a) Teeth small.

x. Small slender compressed fishes with narrow heads and a silvery stripe on the side.

Atherinida.

y. Small or moderate sized fishes with broad, blunt heads and small mouths. Mugilidae

(b) Mouth and teeth large. Sphyronidoe

(B) Ventral fins separate, placed about under breast fins.

(a) Tail fin notably deeply forked. The peduncle narrow and firm, often with a keel of enlarged scales. Scales otherwise small or absent.

x. Scales never rough.

Carangidoe

y. Scales rough. The small spiny back fin much lower than the soft-rayed fin behind it.

Pomatomidae

(b) Tail moderately forked, even or rounded. Scales usually somewhat larger and rough.

x. Anal spines one or two.

(x) Lateral line not extending across the tail fin.

Percidae

(y) Lateral line extending across the tail fin.

Scionida

y. Anal spines three.

(x) Vertical fins not densely scaled. 
(y) Vertical fins densely scaled. Deep compressed fish.

Ephippida

(C) Ventral fins united. Small marine fishes. Gobiidae

(D) Ventral fins placed decidedly before breast fins. Spiny back fin very small. Body tadpole shaped. Mouth large with a projecting lower jaw.

Batrachoidida

(3) Spiny and soft-rayed portions of the back fin united, at least at the base.

(A) Three short spines only in the front of the back fin. A small fresh-water fish.

Aphredoderidoe

(B) An erectile spine on the side of the peduncle. Body deep and compressed with minute scales. Mouth small with incisor-like teeth. Spines and rays of the long back fin little differentiated.

Teuthidida

(C) Ventral fins placed further forward than breast fins. Small scaleless marine fishes. Blenniida

(D) Not as above.

(a) Teeth incisor-like, each tooth with a conspicuous horizontal process or root.

Kyphosida

(b) Lateral line extending across the tail fin. Scicenida

(c) Teeth in the front of the thick-lipped small mouth, large and strong. Scales smooth. Spiny part of the back fin much longer than the soft part. Tail fin squarish. Breast fin rounded.

Labrida

(d) Body very deep and compressed, the soft vertical fins densely scaled, mouth small, teeth fine, brush-like.

Choetodontidae. 
(e) Not as above.

x. Ventral fins without a scaly flap at their base. Upper corner of gill-cover (operculum) with one or two more or less obscure flattened spines.

(x) Pseudobranchiæ (gill-like structure on the inner face of the gill-cover) not well developed, fresh-water. Micropterida

(y) Pseudobranchiæ well developed. Marine.

$\mathrm{x}^{1}$ Eye very large. Color bright red. Priacanthida.

y. ${ }^{1}$ Body deep, compressed. Eye placed far forward near the snout.

Lobotida.

z. Not as above.

Serranidae.

v. Ventral fins with a scaly flap at their base. Upper corner of the gill-cover (operculum) without spines.

(x) Teeth in the back of the mouth, flat molar-like. Anterior teeth more or less incisor-like, sometimes compressed.

Sparida

(y) Upper jaw capable of being thrust far forward. The lower jaw concave. Eucinostomider

(z) Not as above.

$\mathrm{x}^{1} \quad$ Teeth large, unequal. Lutianida

y. ${ }^{1}$ Teeth small. Haemulida

1. Two or three separate soft-rayed back fins. No spines anywhere.

(1) Mouth large, with large teeth. Lower jaw projecting. Color silvery.

Merlucciidae

(2) Mouth and teeth comparatively small. Color not silvery.

Gadidoe 


\section{A Review of the Kinds of Local Fishes}

\section{Sharks and Rays}

\section{(Elasmobranchii)}

Sharks are usually large fishes with the mouth on the lower side of the head. They have a rough scalcless skin which covers both body and fins, and their curiously shaped tails are longer above than below. Dogfish are smaller, but otherwise not different from sharks. The Smooth Dogfish is abundant in all salt waters near New York in summer. It feeds mostly on crabs, which it hunts by scent, and its teeth are small, numerous and blunt, to deal with this kind of food, being unlike those of any other shark. It is not particular in its diet, however, and may be caught with almost any live or dead bait. Other characters which will aid in identifying the Smooth Dogfish are, its slenderness, that it is flattened below, and that the two back fins are of nearly the same size. This species is frequently caught by anglers in pursuit of other fish. Though little used, its flesh is nutritious and palatable, as it well may be, for among the Smooth Dogfish's favorite foods are young lobsters and the blue crab. It reaches a length of about three feet. The common large shark in the latitude of New York is the Brown Shark. Females of this species measuring about seven feet in total length enter the bays in midsummer to give birth to their young. They are destructive to other fishes, consuming large quantities of flatfish in the vicinity of Fire Island Inlet. This species has the first back fin (the front margin of which measures more than half its distance from the snout) several times larger than the second. placed well forward, shortly behind the breast fin; its teeth have fine saw edges, the upper being triangular and much broader than the lower. There is no keel on the side of the tail. Occasional males of the related Cub Shark wander to our shores in summer. This species has a very broad blunt snout, a lower dorsal fin, with front margin one half or less its distance from the snout, and the second dorsal fin a little more anterior in position than the anal. The Dusky Shark, whose status in these waters is uncertain, has a snout like the Brown Shark, dorsal fin even smaller than that of the Cub Shark, and narrower pectoral fin than either. The Edged Shark, a rare straggler from the south, differs from these three in having the upper teeth narrow, much like the lower. Its fins are usually sharply edged and tipped with black. This species is common as far north as the coast of North Carolina. The Blue Shark, growing to be about ten feet long, is occasionally taken in this vicinity, a straggler from the high seas. I'ts first back fin is placed 


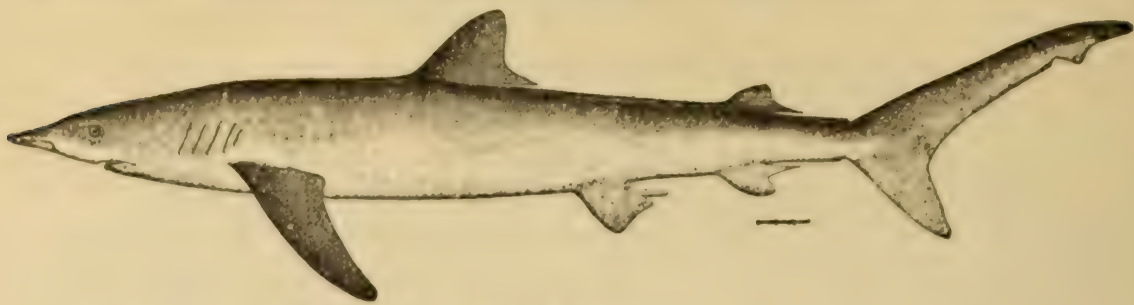

BLUE SHARK

further back, halfway between the breast and belly fins. The Tiger Shark, reaching a much larger size than any of the above, is a rare straggler from the south. Its head is blunt, shoulders heavy, body slender and tapering. All but the very large ones are marked with numerous dark spots. The teeth are characteristic, very broad with rounded coarsely serrate sides, and oblique pointed tips, the teeth of the upper and lower jaws alike. The Hammerhead Shark has the sides of the head reculiarly produced like the head of a flat hammer. It is a swift and vigorous species reaching a large size and often seen at the surface, not rare in this vicinity. Its peculiar head probably functions as a bow rudder. The common Sand Shark bears a superficial resemblance to the Brown Shark but may be easily distinguished by the large second back fin, little smaller than the first. Its teeth are very sharp, white and cat-like, narrow, with small cusps at their bases. It is generally smaller, three or four feet long, with black spots in life. A large species occasionally found off shore is the Thresher Shark with tail remarkably long and slender, about as long as the head and body. It reaches a length of fifteen feet.

The true tropical "Man-eater" or White Shark has never but once been taken in this vicinity; though it has occurred several times further north. It belongs to a particularly swift swimming, voracious group, with the tail fin more symmetrical, crescent shaped, better developed below; and has a keel on the side of the tail like its smaller relative, the Mackerel Shark, which has been taken in our waters. The IMackerel Shark reaches a length of ten feet. Its first back fin is large, placed about intermediate between the breast and belly fins; the teeth are large, slender and sharp without saw edges or basal cusps, while those of the Man-cater are triangular with saw edges. Large specimens of the White Shark or Man-eater are lead white in color, but smaller ones are dark above and white below. It is one of the largest, most powerful of existing fishes. Dr. Jordan tells of finding a fair-sized young sea lion whole in the stomach of one of about thirty feet. 
The Basking Shark is a northern fish, very rarely straggling southward as far as New York, and although it has oceurred in our waters, it may not do so again for many years. It is as large as any known fish, reaching a length of over thirty feet. It swims sluggishly in the open ocean, generally near the surface; doubtless, like the whalebone whale, subsisting on small food which it strains from the water. Its teeth are very small, its gill-slits very long, taking in almost the entire depth of the body, and it has the keeled tail of the mackerel shark.

The Spined Dogfish is readily told from all our other sharks by the single stout spine in front of each of its back fins. It is small (three feet being a large one), slender, and travels in schools sometimes of immense size. It occurs off our coast abundantly in fall and winter.

Though little marketed, the Spined Dogfish is an excellent food fish, if properly cooked. The flesh should be soaked or boiled in vinegar, or some acid, cooked thoroughly, and with plenty of butter or oil. This species occurs in tremendous schools, especially in autumn. It has been rather extensively canned as "Greyfish."

The Rays are shark-like fishes with peculiarly flattened bodies adapted to life on the bottom. The breast fins are expanded and confluent with the body, the body and breast fins forming what is called the disk. Some of the most remarkable existing fishes are intermediate between the shark and the ray type. One of these, the Monkfish, is an uncommon summer visitor to our coast. It may be at once recognized by its circular head, constricted neck and wing-like breast fins. The Skates are more or less spiny rays with rhomboidal disks and slender spiny tails. Their two dorsal fins are placed close together, far back on the tail. We have four species of skates. Our commonest species is a small one, the Common Skate, reaching a length of one or two feet. The snout end of its disk is broadly rounded, the small teeth are in about fifty series, whereas those of the Big Skate, which resembles it in share, are in about ninety. This latter fish usually has a large ocellated spot on either side of the upper surface. It reaches a length of three feet. The small Clear-nosed Skate, which occurs in summer, has a pointed snout with translucent area on either side of it, and the large Barn Door Skate, which reaches a length of four feet, has the head and snout long. produced, ending in a blunt tipped angle. The egg-cases of skates are familiar objects washed up along the seashore, leathery, rectangular, with lengthwise prongs at the four corners, usually blackish: The skates are first-rate food fish, though not eaten by our native population, who do not like their looks. 


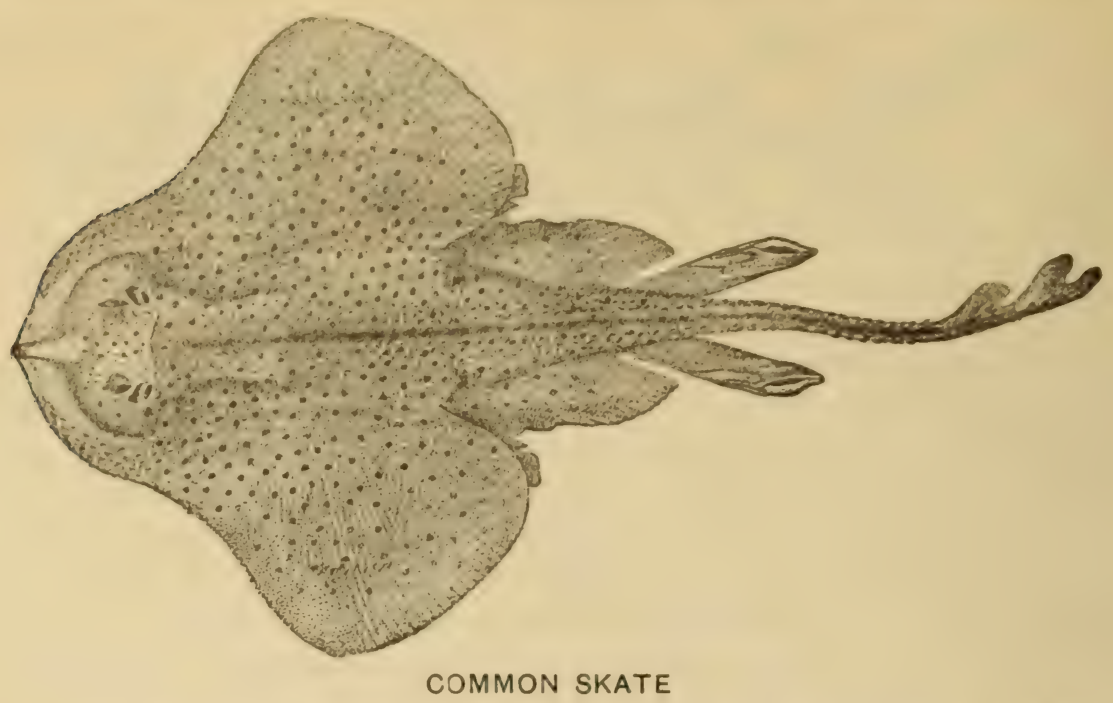

The Torpedo, unlike the skates, has no spines anywhere and the angles of the disk rounded. It has conspicuous spiracle holes behind the small eye, a squarish tail fin, and is blackish in color above, white beneath. Bearing no armature of spines, this remarkable fish protects itself by its ability to give a severe electric shock.

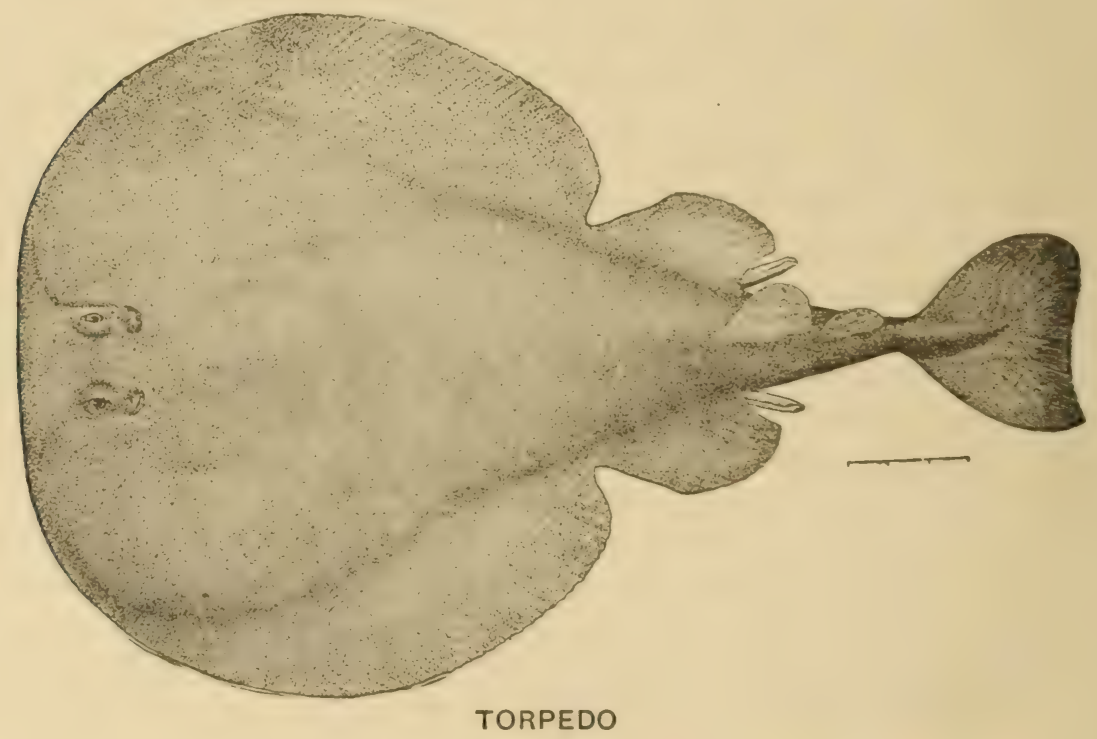


Numerous species of Sting Rays occur on southern coasts and one of these, the Common Sting Ray, reaches our shores in summer. Its disk is roundish. with a wide angle at the snout, and its greatest breadth forward. Its tail is long, slender, finless, whip-like, more than twice the length of the disk, with a wing-like expansion below, armed near the base with a single large, dangerous, saw-edged spine. This species reaches a very large size. It may sometimes be seen through clear water lying on the bottom. The Butterfly Ray is a small southern species not more than two feet in length that sometimes reaches our waters. It has the disk much broader than long and a small mouse-like tail about one third as long as the disk. Well-named Butterfly Ray, it flits through the water with its great wings much as butterflies through the air.

In the Cow-nosed Ray the disk formed by the body and breast fins is diamond shaped, pointed at the sides, about one third broader than long. The head is convex, not flattened as in the skate or sting ray. The tail is lash-like, a little longer than the disk, with a small back fin followed by a saw-edged spine at its base; the muzzle deeply emarginate, color brownish. It reaches a large size, has hard paved teeth for eating mollusks, and is said to be particularly destructive to the soft clam.

\section{Sturgeon and Gars}

(Ganoidei)

In the course of geologic time, before the modern hard-boned, compact fishes covered with thin overlapping scales had been evolved, the waters contained soft-skeletoned species which are sometimes classed together in a heterogeneous group called Ganoids. Remnants of this tribe still remain scattered over the world, now everywhere in the minority. The Sturgeons, noted for the "caviar" which is made from their eggs, belong to it. The Common Sturgeon is a large fish reaching a length of eight feet, which enters the rivers of our Atlantic coast from the sea, as it also does those of Europe. Its snout is long and pointed, its rather small mouth situated on the lower side of the head, its tail unsymmetrical, somewhat shark-like, and its body instead of being covered with scales is armed with rows of hard bony plates. Formerly common in our waters during the summer, it has been too diligently fished for and has become rare. A much smaller species, reaching a length of only two feet, also occurs with us. It is known as the Short-nosed Sturgeon and has the snout comparatively short and blunt, only about one fourth as long as the head. 


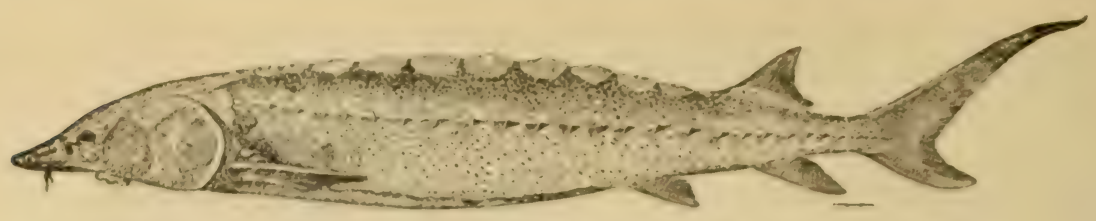

SHORT-NOSED STURGEON

Several species of Gar Pikes, distantly related to the sturgeons,occur in fresh waters outside our limits and one of these, the Long-nosed Gar, occasionally occurs within fifty miles of New York. Gars are sluggish, armor-clad, piratical fishes. Their long cylindrical bodies lie motionless, balanced, in still water, or drive forward suddenly with great velocity to seize some luckless fish that has wandered within range. Their jaws are hard and elongate, armed with formidable teeth; the tail fin, which does the propelling, is rounded but somewhat unsymmetrical, longer above; and gars may always be recognized by their peculiar bony diamond-shaped scales very regularly placed, divided one from another by grooves. In the Long-nosed Gar, the distance from the eye to the tip of the narrow, beak-like snout is more than twice the length of the rest of the head.

\section{Catfish and Carp (Ostariophysi)}

Catfish and allies of the Carp are with few exceptions fresh-water fishes. The latter swarm in the lake and river systems of the northern continents. The former are most abundant in South America where many very peculiar ones have been evolved. All our catfishes are of the same general type, with large blunt heads, the transverse mouth surrounded with whisker-like barbels, the skin soft and scaleless, the back and breast fins armed each with a spine. Behind the back fin is a small fleshy adipose fin. This adipose is, in all but two, short, rounded and free behind, but in the Stone Catfish and Mud Catfish it is keellike; in the former comparatively high, and continuous with the much rounded tail fin, in the latter lower, with a shallow notch marking it off but not separating it from the slightly rounded tail fin. Both are of small size, the former five, the latter eight inches, and inhabit the bottoms of small brooks. They secrete a poison which causes the wound from their breast fin spines to resemble the sting of a wasp.

Two species of salt-water catfish sometimes occur with us in the summer; both have forked tails, six instead of eight barbels as in the fresh-water forms, and are more or less dark gray above, white below. 
The Sea Catfish is in no other way remarkable, but the Gaff-topsail Catfish has very long band-like barbels extending from the corners of its mouth, and long filaments extending from the spines in the back and breast fins. The Sea Catfish is an abundant omnipresent fish further south, entering inshore waters otherwise almost barren of fish life. It is very active and hungry at night. Of our remaining four fresh-water species the small common Horned Pout may be distinguished by its

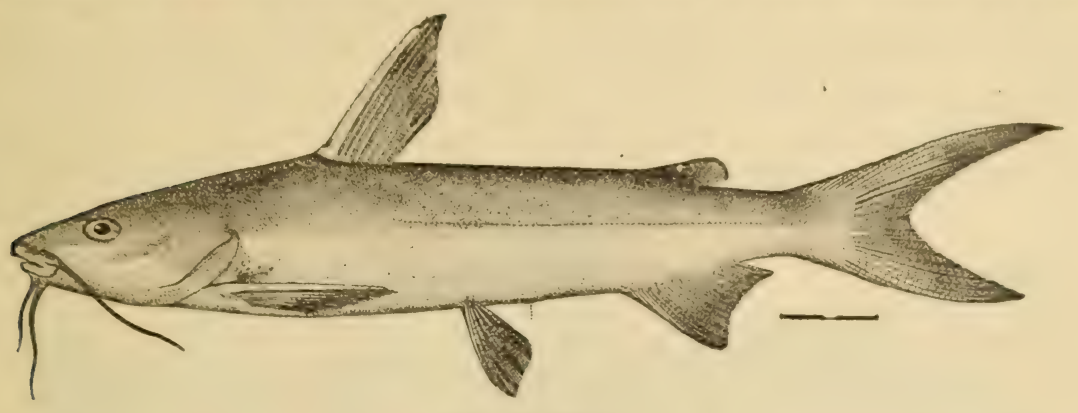

SEA CATFISH

unforked tail fin. It reaches a length of eighteen inches and is abundant everyhwere, but especially in still waters. The Channel or Spotted Catfish, abundant in the streams of the Mississippi, is the most prized food of any catfish, and has been locally introduced. It may be told by a continuous bony bridge under the skin from the top of the head to the back fin, or more readily by small round dark spots which are almost always present on the sides. The giant Mississippi Catfish, locally introduced, reaches a length of five feet and a great girth. Small individuals may be told from the smaller native White Catfish by the larger anal fin. The White Catfish extends north to New York in coastwise streams. The anal fin has twenty-five to thirty-two rays in the Mississippi, nineteen to twenty-two in the White Catfish.

In most sections of the country, catfish are not esteemed as food, but whenever taken from clear, cool water, they are palatable, and when properly cooked, even delicious, resembling the ecl somewhat in texture and flavor. Catfishes are especially adapted for stocking ponds and sluggish streams with muddy bottoms, waters not suited to game fishes. The Mississippi catfish reaches the largest weight of any of our srecies, sometimes over one hundred pounds. The residents of Missouri are especially fond of Catfish, a taste which they carry with them to other parts of the country, and on the Columbia River I have 
heard such persons complain that the salmon is inferior to the catfish of their native state.

Our carps are fresh-water fishes with forked tail fins and a single fin with no spines, or at most an iritial one, in the center of the back. They have no teeth in the mouth but one or two rows on the lower pharyngeal or throat bones. Superficially the carps resemble only the herrings, with which they might be confused by a novice. It takes little practice, however, to recognize at a glance the coarser structure of a carp from that of the finer more active herring. The carps fall readily into two divisions, the Suckers, with small thick-lipped, downwardly protractile mouths, and a single row of numerous comb-like teeth on the pharyngeal, and the true Carps. The White Sucker has small scales

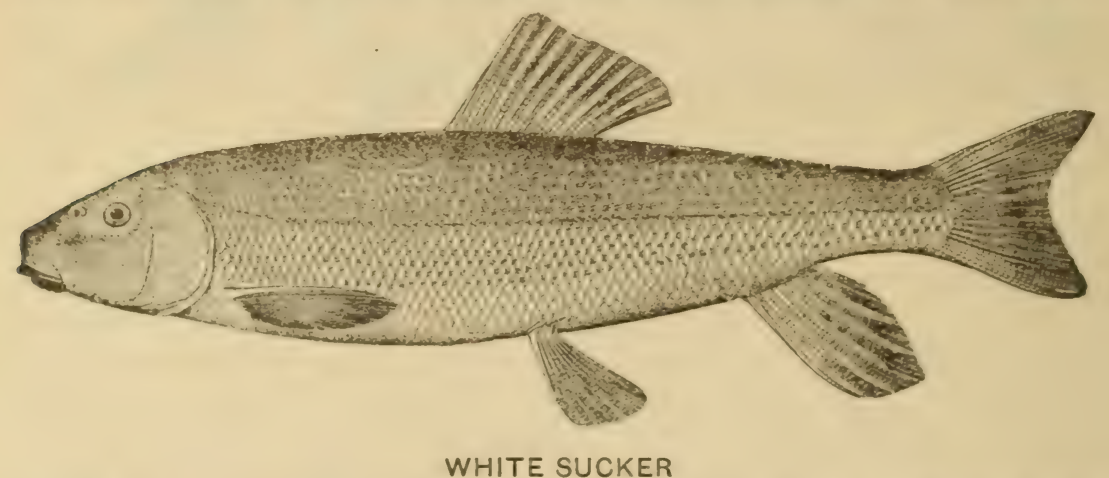

(sixty-four to seventy cross series) and a lateral line; the Chub Sucker and Red Horse, large scales (about forty-three to forty-five cross series). The Chub Sucker has not and the Red Horse has, a lateral line. The two former are common, the latter rare. The mouth of the Chub Sucker is more normal, thinner lipped than those of the other two, and its young, which characteristically have a black lengthwise stripe, look not unlike some minnows.

The true carps do not have a sucking mouth and their pharyngeal teeth are few, in one or two rows. Many of them, especially the small ones known as Minnows, are very difficult to tell apart, but the Cut-lip Minnow may be distinguished at sight by its three-lobed lower jaw which looks positively deformed. It would be interesting to know what hahit is served by such a peculiar structure. Almost all the remaining carps have the upper jaw protractile, that is, capable of being thrust forward and with a complete groove separating it from the forehead when in its normal position. An exception is the Black-nosed Dace or 
Minnow, which may also be recognized by its small scales (about sixty-four cross series). This is the eommon minnow found in small stony brooks. It has a bold black stripe from snout to tail. The rare Long-nosed Dace is like it but has a longer snout projecting notably beyond the mouth, the distance from its tip to the eye in the adult twice instead of one and a half times the length of the eye. The Longnosed Dace also has no black stripe or a poorly defined one; the males of both species assume bright rosy colors in the spring. The most abundant minnow in this vicinity is probably the Golden Shiner. It occasionally

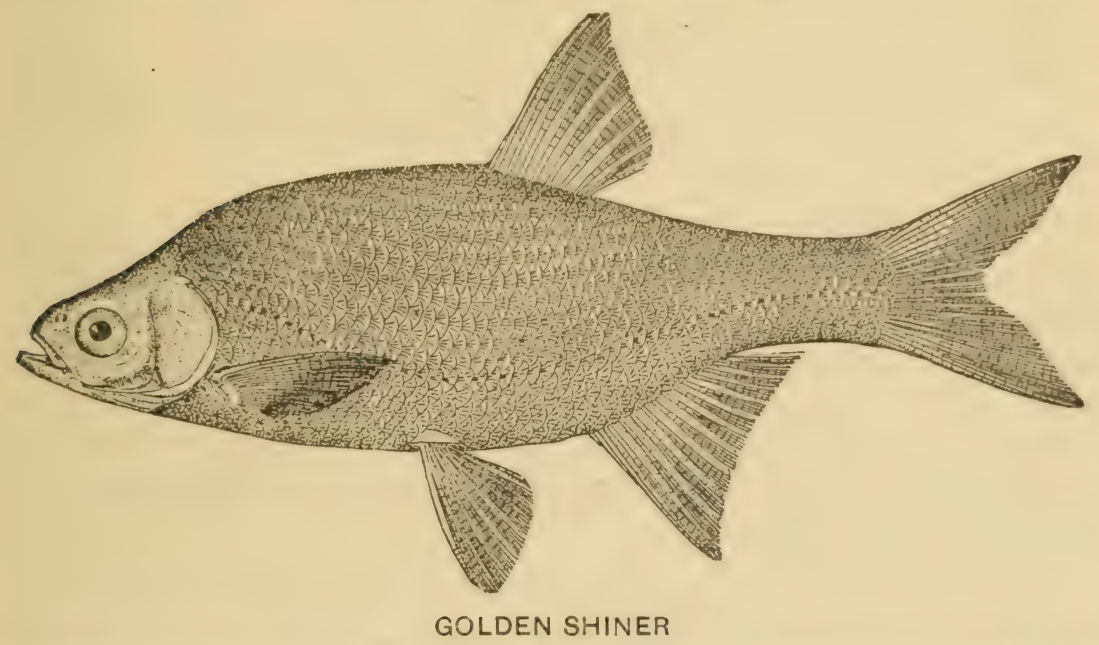

reaches a length of twelve inches and the adult is a rather deep compressed fish, but schools of the more slender young are more frequently encountered. These might easily be confused with other minnows, but the species may be recognized by the fact that the belly behind the ventral fins forms a narrow keel over which the scales do not pass. The back fin begins behind the ventral fins instead of directly over them as is usual and the anal fin is longer than in most species (of twelve to fourteen developed rays). The adult is greenish above, silvery on the sides with golden reflections, fins yellowish or even slightly orange. The young are silvery with beautiful pearly luster and an ill-defined dusky lengthwise stripe posteriorly. They swim less steadily than the Black-nosed Dace, for instance, frequently gliding forward motionless after a vigorous stroke or two of the tail. A European fish, the Rudd or Pearl Roach, which looks not unlike the Golden Shiner, has been introduced and is abundant in the lakes of Central Park, New York. It has the keel-like 
edge behind the belly fins but this is covered by scales; its color is whiter in the adult, with sharply red fins, and its pharyngeal teeth are quite different. In the Golden Shiner there is a single row of teeth, their inner edges more or less wavy only, instead of sharply saw-edged, and no second shorter row of smaller teeth as in the Rudd.

European species which have been introduced and are more widely spread are the stout-bodied Carp and Goldfish which may be recognized by their long back fins of eighteen to twenty soft rays, preceded in each case by a stout spine. The former has four short barbels about the mouth, the latter none. Carp grow to be a foot and a half or more long. Goldfish are much smaller. Both species multiply prodigiously in muddy waters which are not too swift, the former, especially, rooting in the mud like pigs.

Though generally looked down upon as food fish, the Carp has this advantage, that it can be transported to considerable distances alive. It is sold in very large quantities in New York City, affording inexpensive and nourishing food. In this country the Carp, so far as we know, is never sought as game fish, but since early times European anglers have gotten enjoyment from its pursuit. This is one of the largest species of the Minnow family, commonly reaching a weight of five pounds and sometimes a much larger size.

Two other European species have been introduced and occur locally, the Tench and the Golden Ide. The Tench may at once be recognized by its unforked tail fin, emarginate at most, very small scales, ninety to one-hundred-and-five cross series, and long barbel at the corner of the mouth. The Golden Ide is an artificial variety of the Ide, of a golden color like the Goldfish. Where the Goldfish runs wild, it reverts to a dull greenish, golden examples occurring only occasionally. It is probable that the Golden Ide does likewise, in which case it would be easily confused with some of our native species which have not yet been mentioned, and is taken up with these in the following artificial Key.

Carps from within fifty miles of New York City, with the lower jaw not peculiar and three lobed, the upper jaw protractile, the belly not compressed to form a keel, the back fin short not beginning with a stout spine, and the scales not very small, less than seventy-five cross series, are numerous and difficult to identify. The following Key will be found useful in determining them. 
I. Scales small, 47-60 cross series.

1. Teeth in two rows, not saw-edged, the secondary row with three teeth.

Golden Ide

2. Teeth of the second row not more than two.

A. A black spot at the front of the base of the back fin. Upper jaw with a small barbel in the adult. Grows to a length of ten inches.

Horned Dace

B. No black spot on back fin. No barbel. Reach a length of five inches.

a. Lateral line complete, reaching the base of the tail fin.

Rosy Dace

b. Lateral line more or less incomplete, usually ceasing behind the middle of the body.

Goldthread Shiner

II. Scales larger, 30-46 cross series.

1. Peritoneum (i. e. lining of body cavity) black, a single row of four teeth.

A. About 38 rows of scales, sides silvery.

Silvery Minnow.

B. About 45 rows of scales, color olivaceous, little silvery.

\section{Blunt-nosed IMinnow.}

2. Peritoneum (i.e. lining of body cavity) pale.

A. Scales about 45. Two teeth in the second row and sometimes five in the first. A small barbel on the upper jaw in adult. Reaches a length of eighteen inches.

Fallfish

B. Scales less than 45 , four teeth, never five, in the main row. Smaller.

a. A small barbel on the upper jaw. Scales about 41, one tooth at most in the second row.

Horny-head

b. No barbel on the upper jaw.

a2. Not more than one tooth in second row.

a3. Scales about 39 , not notably deeper than long, sides with a silvery or dusky lengthwise band.

Spawn-Eater

b3. Scales larger, 30 to 37 . 
a4. A large black spot on the upper posterior part of the back fin.

Silverfin

b4. No black on back fin.

a5. Lateral line extending back only a short distance. A bold black stripe from snout to base of tail.

Bridled Minnow

b5. Lateral line extending to base of tail. Lengthwise stripe less black and bold.

\section{Delaware Minnow}

b2. Two teeth in second row.

a3. Scales about 33, a black stripe on sides.

b3. Scales smaller, $37-43$.

Abbott's Minnow

a4. Scales, especially on shoulders, very deep and narrow

Redfin

b4. Scales not especially narrowed. Color translucent greenish.

Raritan Minnow

Of the species in this Key, the Blunt-nosed Minnow, Rosy Dace, Gold-thread Shiner, Delaware, Abbott's and Raritan Minnows and Horny-head are rare in this vicinity and their status not well known. The Fallfish is uncommon, the Silvery Minnow tolerably common, the Bridled Minnow, Silverfin and Delaware Minnow are locally common, the Redfin generally common. Of the last five all are small species except the Redfin, which reaches a length of eight inches. Large specimens of the Redfin have the shoulder region much expanded. Spring males have the lower fins rosy, the region from back fin to snout and lower jaw covered with small tubercles.

\section{Herring, Trout, etc.}

(Isospondyli)

Herring-like fishes like the carns have a single central back fin of soft jointed rays. The mouth varies in size with small teeth or none, and they do not have the comb-like pharyngeal teeth so characteristic of the latter. The species characteristically inhabit salt water, though many of them enter brackish or even fresh water. They are fishes of delicate texture which die quickly out of water.

The Tarpon is a gigantic herring-like fish with protruding lower jaw and the last ray of the back fin elongated in a filament. It commonly enters the mouths of semi-tropical rivers where it is much sought after 
by anglers for sport and occasionally wanders to our vicinity as does the smaller related Big-eyed Herring, a rather large-mouthed elongate cigarshaped fish, separable from our true herrings by its smaller scales and conspicuous lateral line. It may be readily told from a third such wanderer, the cigar-shaped Ladyfish, because the Ladyfish has a short lower jaw beyond which the snout protrudes to some distance. All our other herring-like fishes lack a lateral line.

Two of the remaining species have the last ray of the back fin produced in a filament like that of the tarpon; the Gizzard Shad, a mudeating fresh-water species with protruding snout, uncommonly entering our region in the rivers to the west, and the marine Thread Herring with lower jaw about as long as upper, which sometimes reaches our coast in numbers from the south in midsummer. The Round Herring, uncommon in salt water, differs from all other species in having the belly rounded instead of being compressed to a more or less sharp saw edge. The Menhaden is a deep-bodied, fine-scaled fish differing from its relatives in having the edges of the scales pectinate, that is, with comb-like projections or teeth. Menhaden occur off our shores in immense compact schools throughout the summer. As they swim, their wide mouths are kept constantly open, gulping salt water which is strained out through the exceedingly fine long gill rakers, the fish thus securing a rich food supply. It gets very fat and the compact schools which swim at the surface, often with their back fins out of water, are much preyed upon

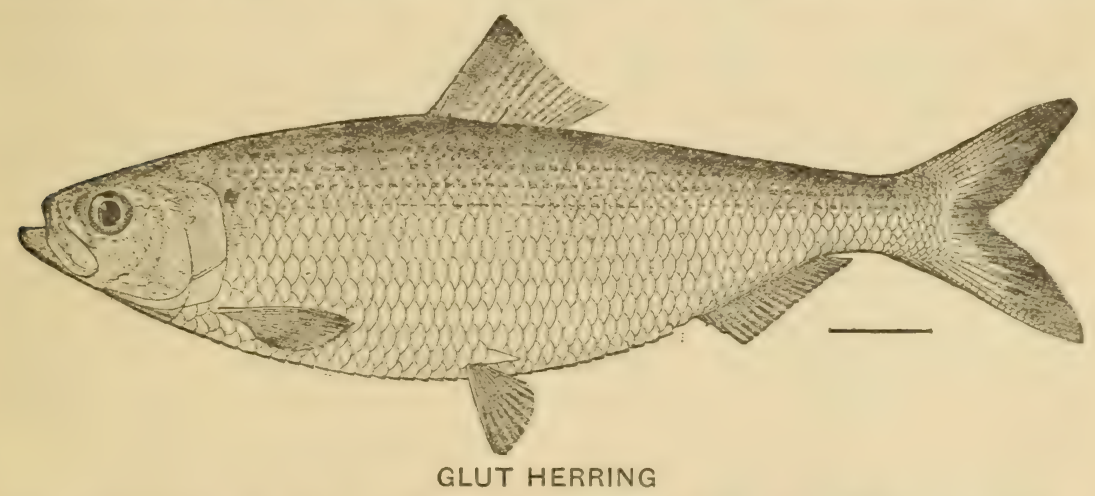

by other fishes as well as being caught in bulk for oil. Of the remaining five herrings, one only, the true Herring, with the belly fins under the middle of the back fin, spawns in the sea. The others run up fresh-water streams and rivers in spring and summer. The Herring also has the 
keel on the lower elge of the bady wakker than in the othars. It is the same fish that is the object of extensive fisheries in Europe, but in this vicinity is irregular in its occurrence, though somatimes abuntant. Must important of the anadromous herrings is the Shad, distinguished by its large size, small scales (about sixty) and deep cheeks, deeper than long. It is still taken in the Hudson River though not as plentifully as formerly. The other three species, with cheeks longer than deep and scales about fifty, are difficult to differentiate. The Glut Herring has the lining of the body cavity black, the others pale. The Hickory Shad has the head long, contained four times in the length to base of tail fin in the adult. The Alewife, the most abundant of the three, has a shorter head (four and two thirds times in the length) and the body heavier forward. It enters small streams to spawn in the spring.

Shad are taken commercially only in nets, but there are numerous instances of their taking the hook. Adult fish average about four pounds in weight, males sometimes reaching a weight of six pounds and females of eight pounds.

The Anchovies are a group of small, frail, marine, herring-like fishes with a very large mouth beyond which the pointed pig-like snout projects. They have a more or less developed silvery band from the head to the base of the tail fin. The Common Anchovy occurs in our bays in summer, sometimes in large schools; it has a longer anal fin than the others, of twenty-five or twenty-six rays, and its silvery band is nurrow and diffuse. The Striped and Silvery Anchovies have about twenty anal rays. They are more elongate, the snouts more protruding, the silvery band better developed, very sharply defined in the former. The Striped Anchovy has a longer upper jaw, its tip reaching backward past the root of the lower jaw, and is flat, compressed. The Silvery Anchovy has a shorter upper jaw, its tip not reaching the root of the lower, and is rounder, more cigar-shaped. Both species are uncommon in summer and fall, though the Striped Anchovy is extremely abundant further south on the coast of Florida. A fourth species, the Flat Anchovy, is recorded in September. This one has the anal fin very short of only fourteen to sixteen rays. It is a slender species with a bold silvery stripe.

Trout-like fishes are allied to the herrings but present a quite different appearance. The scales are fine, not usually noticeable, the mouth is large with strong teeth, and there is a small diagnostic adipose fin on the posterior back, identical with that of the catfish. Six species occur within fifty miles of New York; all spawn in fresh water, 
but the Atlantie Salmon spends much of the rest of its time in the sea, and the Brook Trout sometimes passes the winter in salt water, becoming quite silvery and salmon-like in appearance. The Rainbow Trout has been introdueed from the Pacific slope, where it commonly runs into salt water, and the Brown Trout from Europe; the Saibling, which occurs in Europe and is represented by closely allied races further north in this country, has also been introduced. The Brook Trout is quite generally distributed in clear streams where it was formerly common. It has red

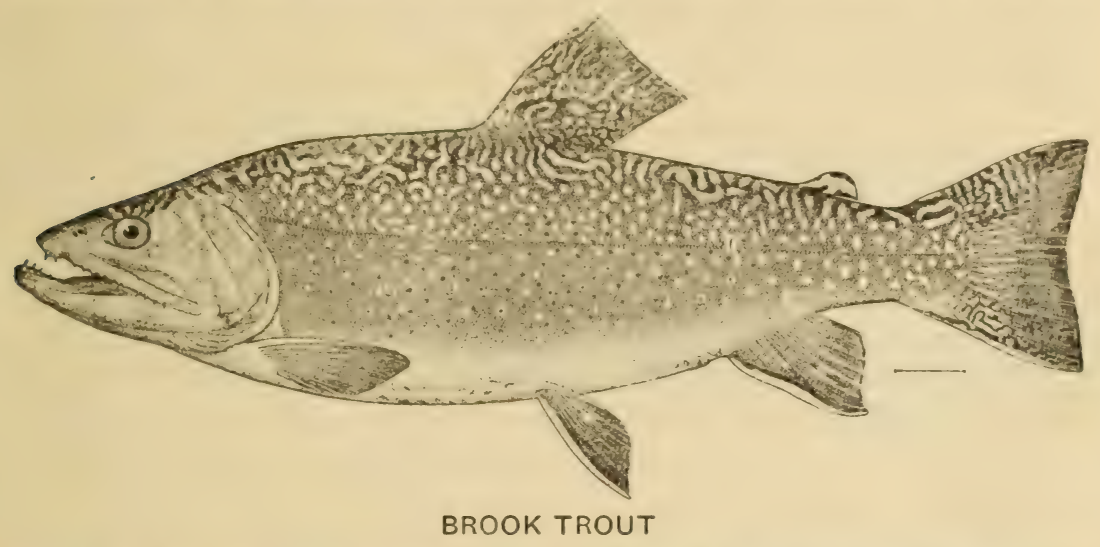

and blue but no black spots on the back and the sides and its mottled back and tail fins are diagnostic. Trout lie in pools or eddies or behind snags whence they dart arvay with lightning rapidity when alarmed, or spring upon their prey when it drifts within range. They feed largely on insects which drop by chance upon the surface of the water. The Eastern Brook Trout is one of the wariest and gamest of fishes, and to land it taxes the sportsman's best skill. It seldom exceeds two or three pounds in weight, and a five-pound fish is a very large one, though there are records of still larger. The Saibling, like the Brools Trout, has no black spots but its fins are not mottled; all our other species have black spots. Highly colored Saibling are more or less golden and red telow.

The Rainbow Trout has very small scales (135-140), many small, black, not $\mathrm{x}$-shaped spots, no red spots or blotches, and a rosy lengthwise band on the sides in the adult. The average full-grown individuals are less than a foot long, but exceptional ones reach a length of two feet. Our eastern Salmon and the Brown Trout have larger scales (about 120). The black spots of the Atlantic Salmon and Land-locked Salmon are 
usually $\mathrm{x}$ or $\mathrm{xx}$-shaped and red spots or blotches are usually present, as also in the Brown Trout. The black spots of the Brown Trout may be either circular or $\mathrm{x}$-shaped, some of them with a pale border. The ground color of the body in this species is brownish or brownish black, unlike the gray of the Salmon or Rainbow Trout, and it has thirty-eight to fifty-one instead of sixty to seventy pyloric cæca (sac-like appendages attached to the front of the stomach).

The Landlocked Salmon is the land-locked form of the Atlantic Salmon from which it is scarcely differentiable. It is a slightly stockier fish, more heavily spotted. The usual weight of the Atlantic Salmon ranges from fifteen to forty pounds. It rarely reaches fifty pounds. The young of salmon and trout, known as parrs, have black blotches along the side.

The Smelt is a small more or less translucent fish with silvery sides living in salt water but entering streams to spawn and often becoming landlocked. It has the large mouth, small scales, adipose fin of the trout and salmon to which it is not distantly allied, but is placed in a different family. Smelt enter rivers and brackish bays during the colder months for the purpose of spawning. They are very abundant, taken in large quantities by nets and by hook and line, and are among the choicest of our food fishes.

The only remaining fish found in this vicinity which has an adipose fin is the Lizard Fish, ${ }^{1}$ an abundant salt-water species which sometimes occurs in numbers in our waters in summer. It has coarser scales than

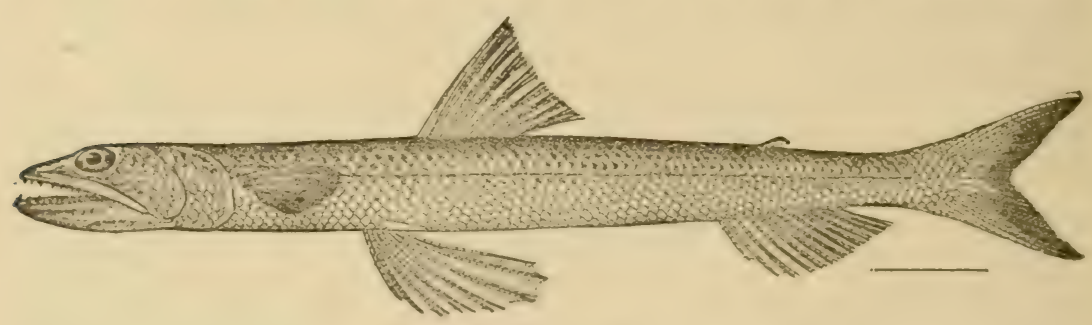

LIZARD FISH

any of the trouts or salmons, sixty to sixty-four counted from head to tail, a very large mouth with formidable teeth and a forked tail fin. It reaches a length of twelve inches, is cigar-shaped, mottled in color, and lies on sandy bottoms in shallow water, darting swiftly upon small fishes which chance its way.

1Although superficially trout-like, the Lizard Fish belongs not to the Isospondyli but to a varied mostly deep water group, the Miomi. 


\section{Eel-Like Fishes}

\section{(Apodes' $\left.{ }^{1}\right)$}

There is a not unnatural popular belief that the Eel is in some manner related to a snake, but the fact is that however, unlike or even unrelated to one another the many kinds of eels which squirm through the "eelgrass" of our bays, the clogging vegetation of tropical rivers and the ooze of the deep sea bottom may be, all are fishes.

The Sea Lamprey, ${ }^{1}$ which reaches a length of two or three feet, has a round sucking jawless mouth armed with concentric rows of teeth. moderately developed eyes, seven small holes or gill openings on the side

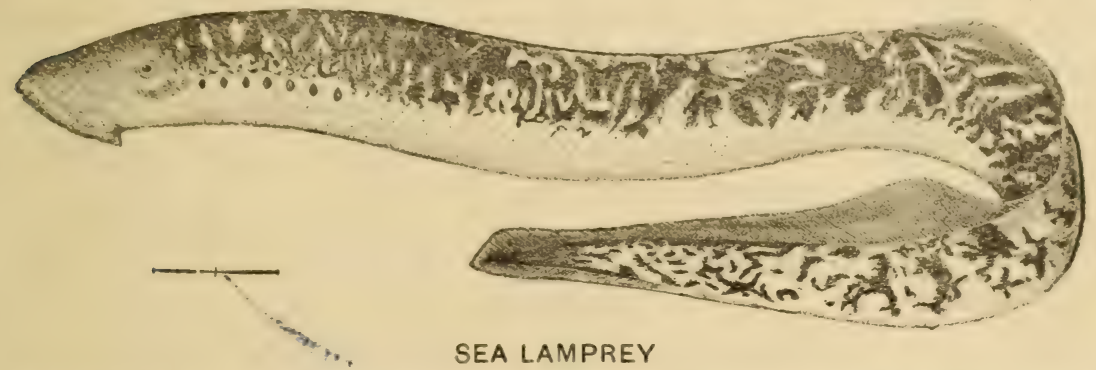

of the neck and a mottled color. In the late spring it enters rivers, clears a circular gravelly nest in their bed by grasping with its mouth and dragging away the larger stones, and in this nest lays its small eggs. Its young resemble it in general form but are at first without eyes or teeth. The Brook Lamprey is found in springtime building nests in smaller streams similar to those of the Sea Lamprey. It resembles its larger relative but is much smaller, from six to ten inches long, bluish black above, silvery below, and has a conspicuous plate in the roof of the mouth with a large tooth at either end of it. The Lamprey is a good illustration of the old adage that appearances are deceptive; he looks like a common eel, but belongs to a very different group of fish-like creatures.

The Common Eel is not at all related to the Lampreys, but is probably descended from ancestors which were more like ordinary fishes. Its gills open to the exterior through a short vertical slit below its breast fin. Its back fin extends around the tail onto the under surface where it becomes the anal fin. The back fin of the Conger Eel begins almost over

\footnotetext{
1The Lampreys are planed here for comparison with the eel although thev have no true relationship with it. In fa $t$ in stru ture they stand entirely apart from all other fishes.

Marv crouns of fishes have given rise to eel-like forms. More or less eel-like marine forms are the band-l'ks, silvery Sand Eel (Se tion VIII); the similar more elongate Cutlass Fish with thread-like tail (Se tion XI): the slen ler, bonv, long onouted Pinefish (Se tion VII). the Ro:k Eel with dorsal fin of short spines, square headed Ghostfish and pezuliar Eelpout (Se tion XIV).
} 
the tip of the breast fin not far behind the head and is usually bordered with black. That of the Common Eel begins much further back. The Conger Eel is found only in salt water but the Common Eel in both salt and fresh, penetrating to almost every little muddy pond or stream in the interior of the country. It breeds, nevertheless, only in the deep sea, and the young are at first flat, transparent and quite un-eel-like. In this larval stage they reach a length of several inches, but as they approach the coast all assume the cylindrical form of the adult ecl, a change accompanied by an actual shrinkage in size. These little cels, still transparent, are very abundant in the weed of our bays at certain seasons. The fact that ecls do not breed in fresh water or even coastwise and practically never are taken with roe in such localities, led to ancient superstitions about their origin. One of the most widely accepted was that they developed from horse-hairs which had by chance fallen in stagnant water, and the slender worms commonly found in such water were looked upon as a transition stage.

\section{Vi. Small Cousins of the Pike} (Haplomi)

The Pikes are fresh-water fishes resembling the Carps in having a single back fin of soft rays, but it is placed much further back. They differ from the carps in having a large mouth with formidable teeth and much finer scales than most of these. They are elongate fishes, seldom seen swimming actively about, which lie in wait for their prey. Three species might be expected to occur in this vicinity but there seems to be no satisfactory record within fifty miles of New York for the Pike proper. It is a large species distributed in northern fresh waters of both hemispheres and reaches a length of four feet. It is bluish or greenish gray in color with paler spots. The cheeks are entirely scaly but the lower half of the opercles is bare of scales, whereas the entire opercle as well as the cheeks of the Banded Pickerel and Chained Pickerel are scaly. The former is dark olive in colnr, the sides marked with about twenty curved more or less vertical dark bars, and the lower fins often reddish or yellowish. This is a small species rarcly reaching a length of twelve inches. It is quite abundant in lowland swamps and streams, especially coastwise. The Chained Pickerel is greenish, generally rather pale with many narrow dark streaks on the sides, mostly horizontal and forming more or less of a net pattern. It reaches a length of two feet and is numerous in clear fresh lakes, often lying motionless, balanced in the water among the lily pads and weeds near shore, ready to dart on any 
living object that is so unfortunate as to come within range, even be it one of its own kind. The writer remembers seeing a little pickerel of but a few inches in length lying motionless in the water with another scarcely smaller one held crosswise in its mouth. This species sometimes, though rarely, attains a weight of seven or eight pounds.

The food value of the Pikes has long been a matter of diverse opinion. Isaac Walton says:

"Roast him when he is caught, and he is choicely good-too good for any but anglers and honest men."

Many persons will be found who claim that the pike is bony and flavorless.

They are very destructive to other fishes in the same pond, such as Carp or Trout.

A number of small minnow-like fishes related to the pikes occur in fresh, brackish and salt water. Their mouths are rather small, but unlike the minnows they have small teeth in the jaws, the tail fins are rounded or squarish instead of being forked, and the black fin is usually more posterior in position.

The IMud Minnow differs from the others in having the upper jaw not protractile and fewer rays in the anal fin, seven instead of ten or

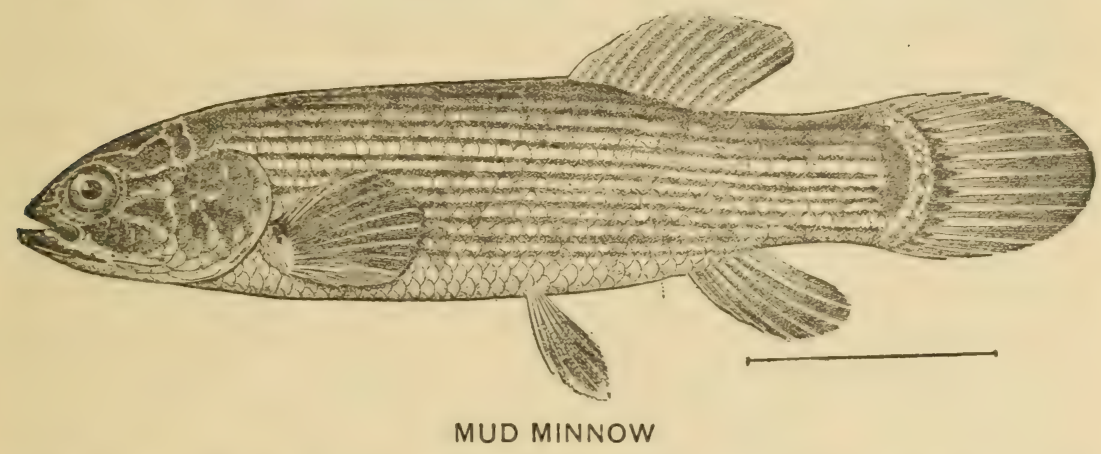

more. It is dark in color with about twelve narrow longitudinal pale stripes and a dark vertical mark at the base of the much rounded tail fin. Full-grown examples are about four inches long. It is most commonly found in very muddy fresh waters, burying itself in the mud.

The Sheepshead Minnow may be recognized by its great breadth, contained two to two and two-thirds times in the length from tip of snout to base of tail fin. Breeding males are bright steel blue and orange; females and young, dull colored with irregular vertical marks. It is 
abundant in salt and brackish water. The Mummichog is probably the most abundant small fish in this vicinity. Its name, sometimes shortened to "Mummy," is of Indian derivation and signifies "going in crowds." It swarms in shallow, salt and brackish waters and very occasionally a specimen will be found in quite fresh water. It benefits mankind by destroying quantities of mosquito larvæ. Its head is broad and blunt viewed from above, and generally it has no noticeable streaks, though sometimes vertical light or dark ones are present. It thus resembles the Fresh-water Killy, but its snout is blunter; it is less trans-

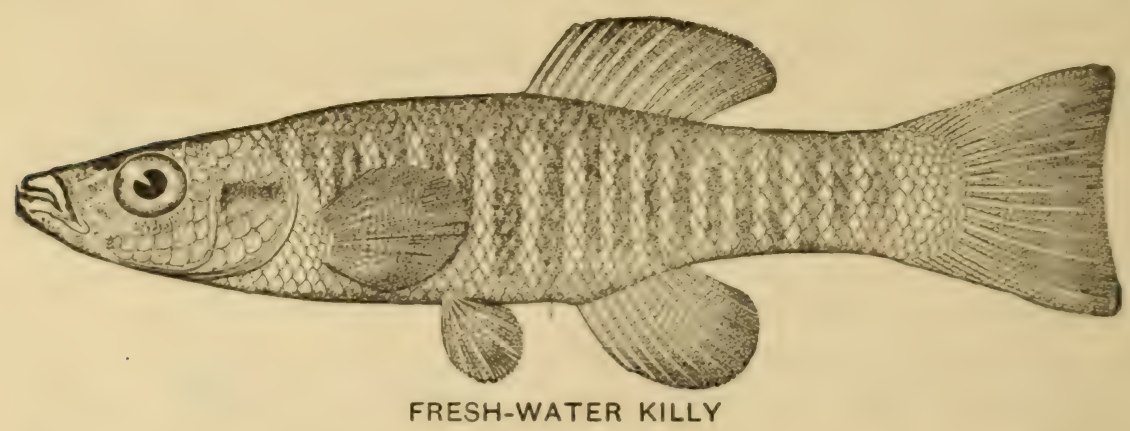

parent and its scales are larger, 35 to 38 instead of about 45 . The Mummichog can undergo great changes of temperature and salinity in the water, will live in water too foul for other species and for a considerable time out of water altcgether; in fact it is of all our fishes one of the most tenaceous of life. The Fresh-water Killy replaces it in pure fresh water and is at times abundant. It is a more delicate fish recognized by its transparency and small scales. The Bass Killy is a more strictly saltwater, generally less numerous species than the Mummichog with which it is often associated. It reaches a somewhat larger size sometimes being six inches long. Its head as seen from above is rather pointed, its sides are whitish, a color never approximated by the Mummichog, and marked by bold black streaks, vertical in the male, horizontal in the female. Lucy's Killy is a small rare salt or brackish water species with broad black vertical bars and may be reccgnized by a large black eye-spot on the posterior part of its back fin. The Rainwater Fish, very seldom reaching a length of two inches, may be recognized by the dark edges of the scales, which make them stand out prominently. Aside from the Sheepshead Minnow it is deeper than the others mentioned, the depth contained only slightly more than three times in the length, and a small 
dark mark at the base of the back fin in front is characteristic though not always present. In this vicinity it occurs coastwise in almost fresh water where some years it is abundant.

\section{Flyingfish, Stickleback and a variety of others}

(Synentognathi, Thoracostraci, etc.)

In this chapter are thrown together for the sake of convenience a number of more or less unrelated species. We begin with the Billfish, a long slender pencil-shaped species with wide-opening elongated jaws, about equal in length, set with formidable sharp teeth. The Billfish, abundant with us in summer, inhabits salt water and also enters the mouths of fresh rivers and creeks swimming in small schools at the surface and preying on other smaller fishes, especially the common Silverside. It reaches a length of four feet but is usually much smaller and is transparent green in color with silvery sides. The uncommon Half-beak is a related species with the lower jaw only elongated, hard and toothless, the upper jaw short and the mouth consequently small.

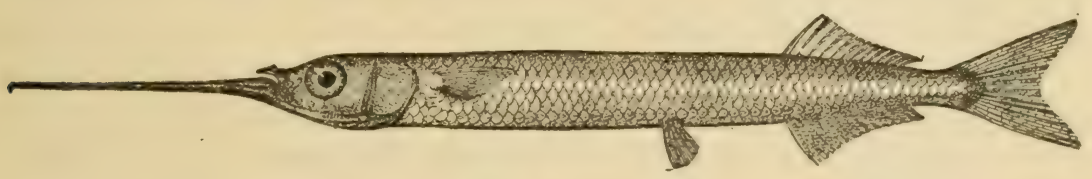

HALF-BEAK

It feeds chiefly on algæ. The Billfish has the most interesting habit of launching itself out of water and skipping over the surface as might a lance or spear. It is a habit shared by others of its elongate relatives which are represented by numerous species in tropical waters. A common species with a flattened body is especially noteworthy as a leaper and can cover considerable distances by turning on its side and letting the air or water strike against its flattened surface. One of the most notable specializations of structure which occur in fishes and serve definite habits is found in the flying fish, which is allied to the Billfish and Half-beak. The elongated and strengthened breast fins of the flying fish, which whən folded extend backward almost or quite to the tail, are spread when the fish leaps from the water, supporting it for protracted journeys through the air. Numerous species of flying fishes occur in warm seas. They are common in the Gulf Stream off our coast but only by ascident straggle inshore. Three kinds have been 
reported. All have the ventral fins somewhat enlarged and spread in flight to aid the breast fins. The Flying Fish proper has the breast fins black with a bold white bar, the anal fin comparatively long, its base a little less than that of the back fin, its first ray nearly opposite the first ray of the back fin, its rays eleven or twelve in number.

The cther two sfecies have the anal fin shorter, its base one-half to two-thirds the length of the base of the back fin, its first ray behind first ray of dorsal, its rays nine or ten. The Bearded Flying Fish has the back, ventral and anal fins without black markings, the Doub.e Bearded Flying Fish has the fins marked with black. The young of both species occasionally have barbels at their chins.

Flying Fishes are small-mouthed, big eyed silvery-sided fishes, somewhat herring-like in appearance, chracteristic of the open sea, occurring often in large schools and trusting to their power of flight to escape predaceous oceanic bonitos and dolphins of which they form the principal food.

Quite unrelated to the group just discussed are the Sticklebacks, among the smallest of our fishes occurring in brackish water among the weed. They may be readily recognized by the short stout disconnected spines occurring on the back in front of the back fin. Their breast fins consist mostly of a stout spine; their mouths are small, their bodies very narrow just in front of the tail fin; the ventral fins consist mostly of a stout spine. The Ten-spined Stickleback has eight or nine free spines before the back fin and one in that fin; the Two-spined Stickleback,

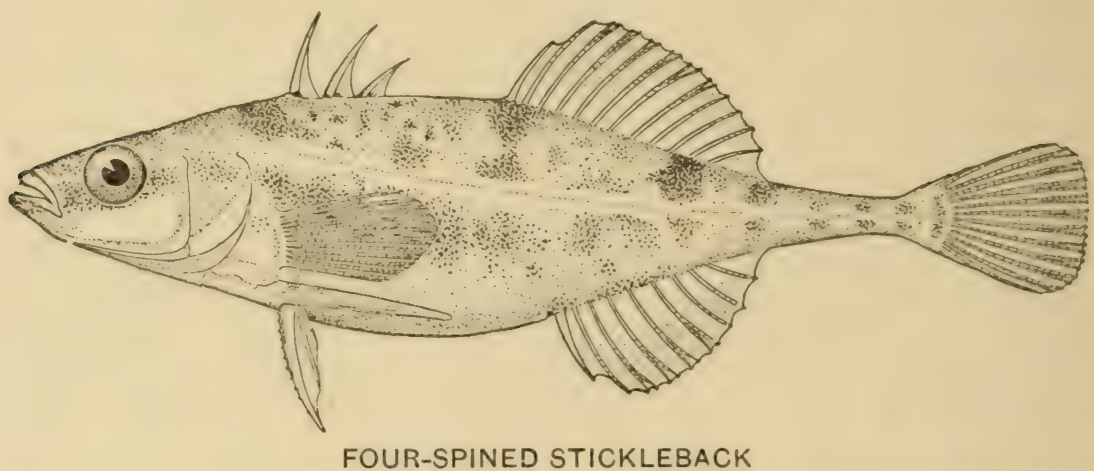

two spines before and one in that fin; the Four-spined Stickleback, three divergent spines before and one in the fin. This latter is the most abundant especially in salt or slightly brackish water. The othertwo are common locally. 
The Trumpet Fish is an elongate peneil-shaped species, superficially resembling the Billfish but probably related to the Sticklebacks. It has a very small mouth at the end of an elongate snout and a peculiar whiplike lash extending from the center of its forked tail fin. It reaches a great size, sometimes being six feet long, but specimens a foot or two in length are most common.

\section{Like the Trumpet Fish the Pipe} Fish has a small mouth at the end of a long snout. It is even more slender, more slender than an eel in fact, but here the resemblance ceases and the relationship between Trumpet and Pipe Fishes, if any exists, is so distant as to be very uncertain. The Pipe Fish has its thin body made up of numerous hard rings or segments, with a little fan-shaped tail fin on the last one. and a small squarish fin of many fine soft rays in the middle of the back. It is not an active swimmer, lurking and squirming abundantly among eel grass and other marine weed and may even be caught in the hand. The male fish is equipped with a pouch in which he carries the eggs until hatched.

The Sea Horse is closely related to the Pipe Fish, having the same fund.mental structure and differing in its broad body, horse-shaped head and prehens.le ta.l, lacking a tail fin. It is rather common and its habits are similar to those of the Pipe Fish. It swims erect.

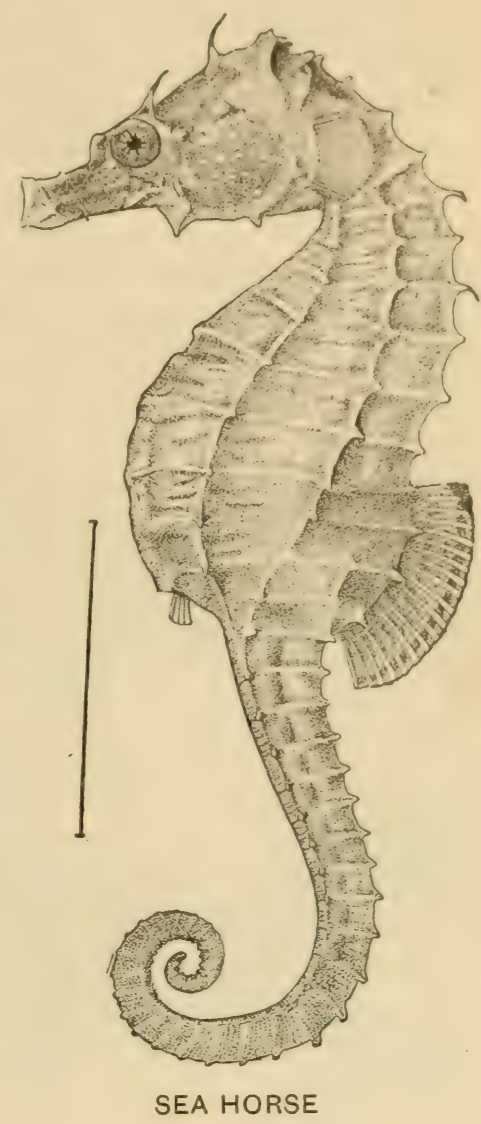

VIII. The Mullets, etc.

(Percesoces, etc.)

We have three families of fishes more or less closely related to the Mullet. All have a small spiny rayed first dorsal fin isolated on the bick in front of the larger soft rayed dorsal. The first family of Silversides contains small species scarcely larger than minnows and with a conspicuous silver lengthwise stripe on the body. They swim in schocls. 
Our three Silversides can be mistaken for no other fishes unless possibly the Anchovies, but the pig-like snout of the Anchovies extending further forward than the mouth will distinguish those at a glance. The Rough Silverside has the hind margin of each scale incised in a manner resembling the teeth of a comb. This renders the fish rough to the touch, by which characteristic it can readily be identified. It is not uncommon southward, but a rare straggler only in the vicinity of New York. The Common Silverside, sometimes called "Spiering," is a very abundant species in salt water near New York where it may be found throughout the year. It also enters brackish bays and estuaries, occasionally ascends to pure fresh water, and forms an important item of food with predaceous fishes everywhere. Large schools made up of Silversides of various sizes may be seen in the summer time from almost any coastwise dock. The Fresh-water Silverside occurs only locally in fresh or slightly brackish water at the heads of the bays, and differs from the common species in

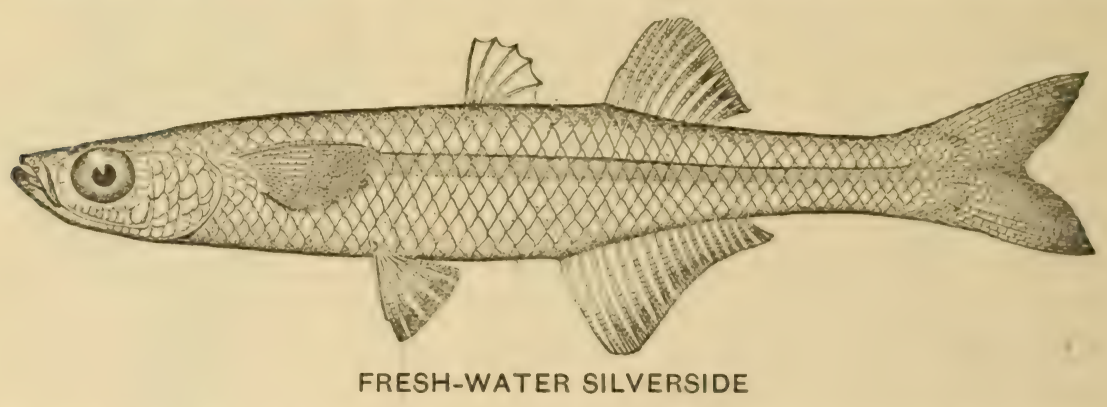

having only about seventeen or eighteen soft rays in the anal fin instead of twenty-three. Although separated by slight technical characters the two are quite distinct economically. Unlike its salt-water relative, the Fresh-water Silverside swims in schools which are generally made up of fishes all of the same size. It is also a fatter and less bony fish and fried well is the delicious crisp "whitebait" which we sometimes see on our bills of fare.

A second family consists of the Mullets proper, fishes of moderate size, generally less than one foot, with more or less cylindrical bodies, rounded snouts, small mouths with a triangular lower jaw. They swim in active closely packed schools and browse in the bottom. They spend the winter with us hibernating in the mud. The Common or Striped Mullet has the soft dorsal and anal fins without scales and the scales of the upper part of the sides are dark centrally, giving more or less the 


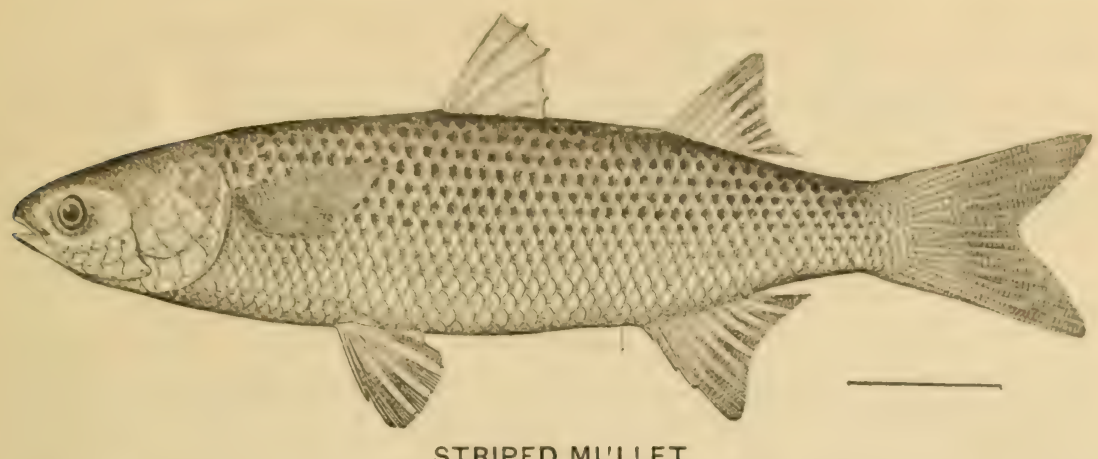

STRIPED ML'LLET

effect of lengthwise stripes. The White Mullet on the other hand has these fins densely covered with scales and the sides immaculate silvery.

The Barracudas are a related more or less tropical family with fins and general form resembling the Mullet, but with predaceous habits. They have a pike-like head with very large mouth, protruding lower jaw and big canine teeth. A single species, the Northern Barracuda, reaches our shores from the south in summer and autumn.

Three other fishes, remotely related at best to those we have just been considering, are the Threadfin, Goatfish and Sand Eel. Threadfin and Goatfish are rather small fishes with forked tails and a weak spined

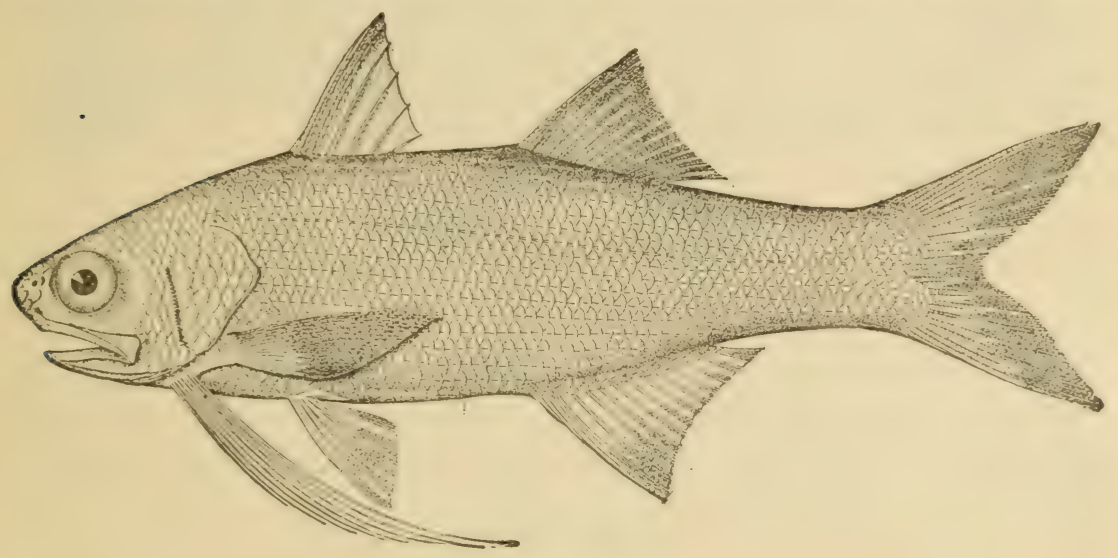

THREADFIN

first dorsal fin about as large as the second dorsal. The Threadfin has a number of thread-like appendages just in front of the pectoral fin and the Goatfish has a long double barbel hanging from its chin. Both species 
are of rare securrence in autumn. The Sand Eel is a silvery ribbon-like fish about six inches long, with a long low fin along the back, a somewhat shorter one posteriorly below, and a forked tail. It is abundant in the

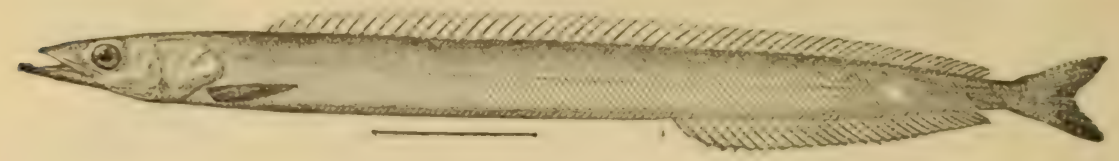

SAND EEL

wash of sandy ocean shores especially in the colder months of the year, diving in and out of the loose sand bottom with great agility. At times quantities of Sand Eels are washed ashore and lie strewn along the water's edge, a rich harvest for the gulls.

For want of a better place we mention in this chapter a small freshwater fish somewhat intermediate in appearance between the killies and the perch-like fishes, namely, the Pirate Perch. It has a single large

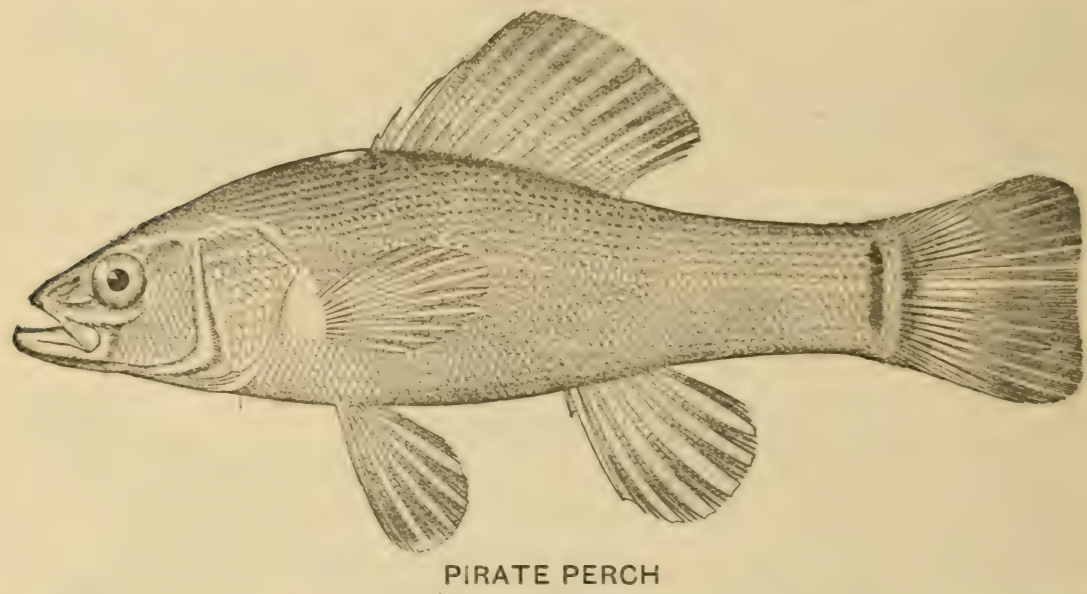

back fin composed of soit rays preceded by three spines progessively shorter, so that the anterior one might be easily overlooked. Its lower jaw projects, its tail fin is squarish with a vertical blackish bar at its base.

IX. Perch, Bass, etc.

(Perciformes)

The Perch, the Bass and their allies are the typical modern spiny finned fishes. They always have a spiny back fin, sometimes separated from the soft rayed fin behind it and sometimes simply forming an 
anterior spiny part of that fin. Their scales are variable although usually of moderate size and rough or "ctenoid." There is no bony stay across the cheek as there is in the sculpin-like fishes, and their small heads and more compressed bodies will separate them from these latter at a glance. Their opereles are furnished with one or more spines which are sometimes weak.

A number of strictly fresh-water species and several that are marine occur locally. We will first consider the former, twelve of which belong to the Sunfish family. In all of these the spiny and soft portions of the dorsal are joined into one fin, and in the Crappie and Calico Bass the anal fin also is preceded by several spines and the compound dorsal is scarcely longer than the anal. These are small pond fishes not native to our region but introduced from the west. Their tail fins are emarginate and there is a concavity in the profile over the cye which is decidedly the stronger in the Crappie. These two species, which are closely related, may further be differentiated as follows: the Crappie has six, rarely five, dorsal spines and the anal fin is not strongly marked; the Calico Bass has seven dorsal spines, rarely eight, and the anal fin is strongly reticulated with dark markings.

The two Black Bass, Large-mouthed and Small-mouthed, belong to this family and may be recognized from other species of Sunfishes by their comparatively elongate bodies, their greatest depth being contained about three times in the length from the tip of the snout to the base of the tail fin. Also their spiny dorsal fin is low, separated from the soft rayed part by a deep notch, connected with it only at the base, and their tail fins are slightly iorked, that is, ccncave behind. The Small-mouthed Black Bass has the smaller scales, about seventy-eight in a longitudinal count, and seventeen rows on the cheek. The ordinary weight of the adult Small-mouthed Black Bass is two and one-half to three pounds, though they are sometimes taken in the north weighing six to seven pounds. The Large-mouthed Black Bass has about sixty-eight scales and ten rows on the cheek. Its young may usually be recognized at a glance by a bold longitudinal stripe, but this becomes less reliable as the fish increases in size, and the decidedly larger mouth of this species is not always a satisfactory character for its identification, as the size of the mouth in Black Bass varies a good deal, particularly with age. The Largemouthed Black Bass reaches a greater size, especially southward. A seven or eight-pound fish is not unusual in Florida, where it is said to have been taken weighing as much as nineteen and one-half pounds. 
According to Goode: "The flesh of the Bass is hard, white and flaky, and not particularly remarkable for its flavor. When sufficiently large it is, perhaps, better that it should be broiled and served with white sauce. The smaller Bass may be treated as pan-fish. They are not well suited for broiling except in the hands of the most judicious cooks."

Our other eight species of sunfishes have bodies comparatively short and deep, the depth usually more than two-fifths of the length. They may be divided into two groups according to the size of the mouth. Largemouthed forms with the maxillary reaching distinctly past the middle of the eye have teeth on the tongue. The Mud Sunfish, a representative of this group, may be differentiated from other species by its smooth scales and convex tail fin. It is a small dark greenish fish of sluggish coastwise southern waters, uncommon in this vicinity. The Rock Bass, which resembles somewhat a black bass in general appearance but is deeper in form with large eyes which are usually more or less red in color, is our other representative of the large-mouthed group, not native but rather generally introduced.

Of the small-mouthed sunfishes three have convex tail fins. The Black-banded Sunfish has ten dorsal spines, some of the median elevated, giving the fin a rather pointed outline. It is pale in color with conspicuous though rather irregular black vertical bars. The Spotted-fin Sunfish and Holbrook's Sunfish are very closely related. They sometimes have

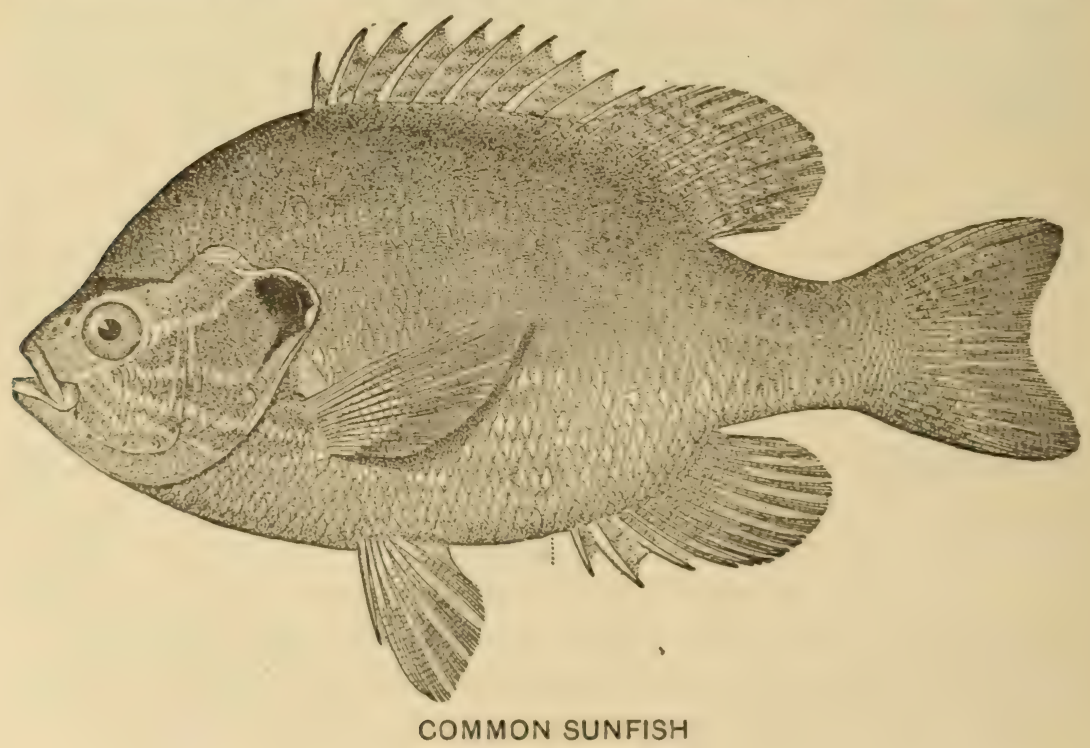


comparatively indistinct cross bars and always small bright spots on the body and fins. They have a black spot on the gill-cover which in the Spotted-fin Sunfish is large, more than half the eye, in Holbrook's Sunfish, smaller. The Common Sunfish or "Punkinseed" has the margin of the tail fin eoncave, the gill-cover prolonged behind in a convex flap or process, black with its lower posterior part always bright scarlet. When highly colored it is a brilliant fish marked with blue and orange and resembles more or less the Long-eared Sunfish which is equally highly colored but with the bright colors in larger areas. The Long-eared Sunfish is somewhat less deep in form than the common species, its depth contained in the length more than twice instead of less, and the flap on the gill-cover is long and narrow, very large and entirely black. Its pectoral fins are short and blunt, not reaching beyond the front of the anal fin, which will aid in distinguishing it from an introduced species, the Blue-gill, which has pectoral fins more or less pointed, not much shorter than the head and reaching to well beyord the front of the anal. The Blue-gill is one of the larger sunfish and perhaps the most important economically. It is dull colored, unlike the common and longeared species.

The Black Bass are the most important of the group with a well earned fame on account of their sporting value. They reach a larger size than the others. The small species are rather slow-swimming, deep-bodied pond fishes, which will thrive in waters where little else but minnows are found. They are the first prize of the small boy angler. Both Large and Small-mouthed Black Bass are sometimes found in the same waters but the Small-mouthed has a preference for clear cold lakes and the Large-mouthed for sluggish coastal streams.

The remaining four strictly fresh-water species of this group belong to the Perch family and have the spiny back fin separated from the soft rayed fin behind it. The Yellow Perch is one of our commonest fresh-water species. Its pointed snout, high back, large spiny dorsal fin and the bold black bars extending half way down on the more or less yellow colored body, are familiar to almost anyone who takes any interest in fishes. Yellow Perch rarely exceed a pound or two in weight, but occasionally grow larger. There is a record of one of four and onehalf pounds from Delaware Bay. The closely related European Perch is known to have reached a weight of nine pounds.

Authorities differ as to the rank they grant the Yellow Perch as a food and game fish. Some pronounce it soft, coarse and insipid. Others 
call it an excellent table fish. One thing is certain, namely, that its capture affords pleasure to many hundreds of persons, both young and old. We quote from Goode's "American Fishes" recipes for cooking Perch:

"How to Cook Perch: This famous dish, water souché, souchy or sokey, does not seem to have been naturalized in America. The following recipe from an old angler's manual seems more practicable than others given by later authorities: Seale and wash your Perch; put salt in your water; when it boils put in the fish with an onion cut in slices; put in chopped parsley enough to turn the water white; scason with salt and pepper, and as soon as the fish is done serve it in a deep dish, pouring a little water over it, with the parsley and onions. Melted butter and parsley should be served in a tureen. Slices of brown bread and butter generally accompany this dish. The writer has tasted a water souché prepared by a famous London cook, but does not remember it with rapture. The favorite American method is to fry the Perch to a crisp, with salt pork rather than with butter. In summer, when the skin is slightly bitter, it may advantagrously be removed, at other times the fish is better simply scaled. This method is hearty and best adapted to the needs of hungry anglers. Many will prefer the continental method of stewing them in vinegar or lemon juice, or in some kind of sour sauce. In Italy they are roasted on the spit without remoring the scales, and bathed while roasting with vinegar or lemon juice, a method not unsuitable to camp life in the woods. The following directions are taken from the International Fishery Exhibition Cookery Book.

"Boiled Perch: Lay the fish in boiling water, with a quarter of a pound of salt to each gallon, and simmer gently for about ten minutes. Garnish with parsley and serve with plain melted butter. (This resembles the water souché).

"Fried Perch: Brush the fish over with egg, and sprinkle bread crumbs over it. Have ready boiling lard; put the fish in and fry a nice brown. Serve with anchovy sauce.

"Perch Stewed with Wine: Lay them on a stew pan with sufficient stock and sherry to cover them. Put in a bay leaf, garlic, parsley, two cloves and salt, and simmer till tender, then remove the fish, strain the liquor, add a thickening of butter and lour, pepper, nutmeg and anchovy sauce; sit it over the fire until somewhat reduced, pour over the fish and serve. 'Broiled Perch Flitters' are spoken of with enthusiasm by early gourmets." 
The Pike Perch is closely related to the Yellow Perch but reaches a much larger size, sometimes being three feet long and weighing between ten and twenty pounds. It is an elongate slender fish. Its mouth is armed with large eanine teeth, and is much larger than that of the Perch, in fact, it is somewhat Pike-like in general appearance, although its fins resemble those of the Perch with which its true affinitics lie. The Pike Perch is a native to the north and west of our locality and has been introduced here. It has a considerable commercia! value, indeed is one of the most important fresh-water fishes, commonly reaching a weight of ten pounds, and sometimes growing much larger, thirty-six inches or more in length, with a weight of twenty or thirty pounds. Closely related species are extensively marketed in Europe.

The Johnny Darter and the Fusiform Darter are small, elongate, perch-like fishes which frequent the bottoms of small streams. They usually take advantage of their concealing coloration by lying motionless on the bottom, when they wish to change their position, doing so with a swift darting motion. The species are really very much alike superficially and in color. The mouth is rather small with the upper jaw the longer and there is usually a dark, narrow vertical bar below the eye. Both have rather cylindrical hodies. They frequently bury themselves in the mud or trash at the bottom. The Johnny Darter has higher and more finely speckled fins than the Fusiform Darter, the pectoral fin being about equal in length to the head, and the spiny back fin being about two thirds of the same; whereas in the Fusiform the pectoral is only about two thirds of the head and the spiny back fin less than one half. In the Johnny Darter the top of the head is only slightly convex, whereas in the Fusiform Darter it is strongly so.

There are two fishes found both in fresh and salt water which form a connecting link between these purely fresh-water perch and the marine species of bass. The first of these is the Striped Bass, a fish reaching a weight of twenty-five, fifty or even one hundred pounds. Like its ally the Perch, it has two dorsal fins, the first consisting of spines and the second of soft rays. It is a moderately compressed, well formed fish, tapering at the head and tail, with a forked tail fin. The mouth is rather large and the lower jaw slightly projecting, the upper jaw extending back to well under the cye. There are about sixty scales in a lengthwise series; the scales are white, those of the back and sides with dark basal spots which form narrow lengthwise dark stripes on the fish's body, about seven or eight in number. The Striped Bass is caught from 
our ocean shores and also ascends the Hudson River abundantly. It is the finest food fish taken locally. Before the Weakfish arrive, rod and line anglers from the city often take their boats up the Hudson River in pursuit of Striped Bass. After the Weakfish have gone, Striped Bass are again in season. They are now often fished for off the beach by casting through the surf. This is the type of fishing hereabouts in which the catch of fish is of least importance.-Just an occasional Bass to lend a touch of sanity to the performance will keep a whole row of anglers on the beach rying with one another in the skill and distance with which they can cast through the surf. Most of the Bass now taken near New York are small, from two to six or seven pounds in weight. It takes especial skill to hook and land the bigger ones, unless by luck.

The average maximum weight of the Striped Bass is probahly about twenty pounds. It not infrequently reaches fifty pounds, but rarely exceeds that size. There is a record of an 112-pound fish from Cape Cod, however.

The well-known White Perch is a close relative of the Striped Bass and agrees with it in essentials of structure. It is characteristic of coastwise ponds but also found in brackish or even salt water. It is a fish somewhat deeper bodied than the striped bass, its depth contained two and two thirds times in its length to the base of the tail fin. Its mouth is smaller than that of its relative, its tail fin only slightly forked. Its color is uniform silvery or whitish on the sides and more or less olivaceous on the back. This is a fish about the size of a Yellow Perch or a trifle larger, and as a table fish superior to that species. It may readily be told from the Yellow Perch by the absence of black bars on the sides. The White Perch is one of the most universally popular panfish throughout the Atlantic seaboard. It reaches a weight of little over two pounds. The White Bass is an inland rapresentative of the Striped Bass from the Mississippi valley and Great Lake region. It has similar stripes but is a deeper bodied fish with a more convex back and longer anal spines, the longest about one third as long as the head. It has been inrtoduced locally.

The Sea Bass is one of our commonest local food fishes most plentiful on fishing banks a little off-shore, and the young abound in coastwise bays in autumn. Its spiny dorsal fin is joined to the base of the soft dorsal as in the case of the fresh-water sunfishes. The tail fin is rounded. There are filamentous appendages from the tips of the dorsal spines and one from the upper corner of the tail fin which give the fish a rather outlandish appearance. The mouth is large, the color blackish. 
The young have a dark lengthwise stripe. This is one of our best food fishes. The hardness of f'esh makes it desirable for packing in ice, and prevents rapid deterioration in hot we.xther. It is an excellent chowderfish and delicious boi'ed or broi'ed. It is the species most sought in summer by the steme:s which regularly take fishermen from New York to the outsicle banks off the Long Island and New Jersey shores. A five-pound Ser Bass is an unusually large one, but there are records for twice that weight. Of cceasional occurrence near New York are the Deep Eigeye and the Wreckfish. The young of the former have keen taken on several occasions. It is a deep compressed fish with a back fin consisting of ten strong spines and a short soft portion, with rather smsll rough scales, and an even or slightly rounded tail fin. It has a rather large oblique mouth, a very large eye and is deep red in color. A single straggler of the Wreckfish has been taken near New York in August, a species with small rough scales, large mouth, projecting lower jaw, spiny and soft dorsal fins. It is peculiar in that the head is armed with rough spinigerous crests. The Triple-tail is a rather large southern bass-like fish which occasionally straggles northward to our shores in late summer and autumn. It has a deep flattened body somewhat concave

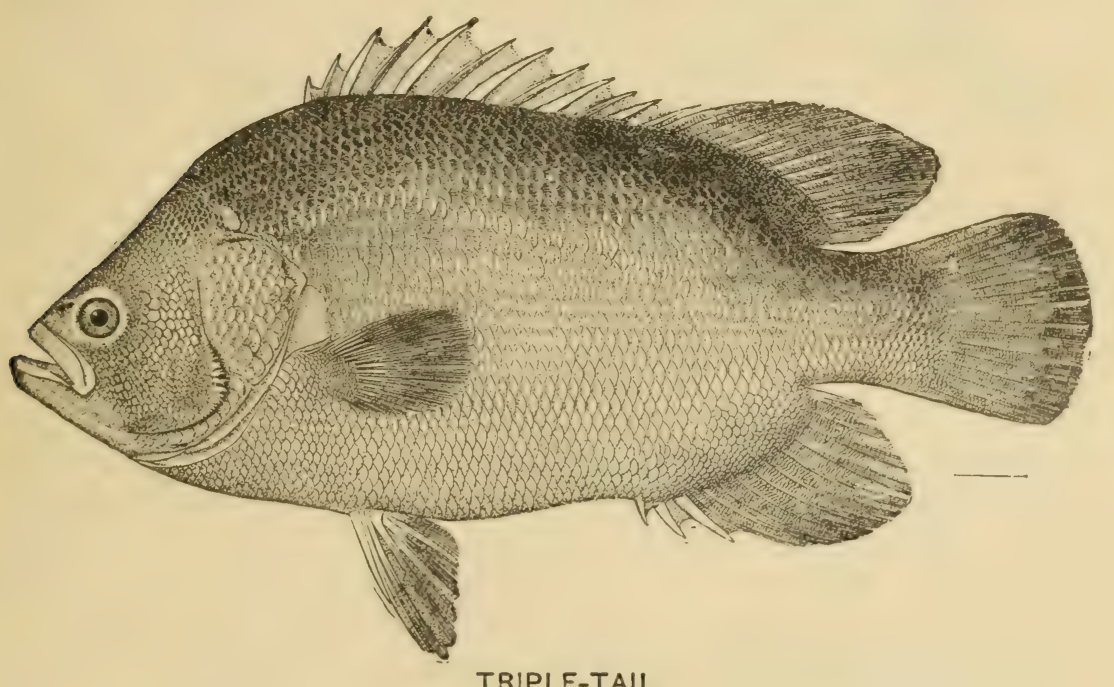

TRIPLE-TAIL

in outline at the nape. Its lower jaw is projecting, its snout short, the eye placed far forward. The somewhat pointed soft back fin and anal fin proiect backward on either side of the slightly rounded tail fin. 


\section{Weakfish, Porgr, etc. (Perciformes, continued)}

We have several families of spiny finned marine perch-like fishes which differ from the true perch and basses in that the maxillary or upper jaw bone slips for most of its length under the preorbital, which forms for it a more or less distinct sheath. The gill-cover proper is also without spines (except in the drums) and the ventral fins have an accessory scale. There are six of these families represented, the Snappers, Grunts, Porgies, Gerrids, Kyphosids and Weakfish or Drums. A single species of the Kyphosids, a herbivorous family, wanders to us occasionally in fall from tropical waters where it makes its home. It is the Bermuda Chub, a small compressed fish with small mouth, low fins and a forked tail. The teeth in its jaws are of the incisor type, each tooth with a conspicuous horizontal process or root. Its spiny dorsal fin of eleven stout spines is depressible in a groove of scales. It is black in color. In the Gerrids, the spines of the premaxillary extend backward to the nape so that the mouth is excessively protractile (that is, the upper jaw is capable of a great extension). The outline of the lower jaw is concave. Numerous species of this family, small compressed silvery fishes with deeply forked tails and rather large eyes, occur in tropical waters, and a single one, the Mojarra, is of accidental occurrence near New York in August. The Snappers may be told from the Grunts and Porgies by their larger mouths and stronger teeth. Unlike these latter they have teeth on the vomer or central bone on the roof of the mouth. Snappers are abundant in species and individuals southward, and young of the Red Snapper have been taken here in October, though the species really has no place in our ichthyfauna. The Porgies have teeth of the molar type (broad and blunt) on the sides of the jaws. In the Grunts they are not of this form. The Pigfish is the Grunt which straggles farthest to the north and sometimes is common near New York in late summer and autumn. It is a compressed fish with a rather small mouth placed low. Its tail is moderately forked, the back fin long, composed of spines and soft rays with practically no break in outline between the two. There are twelve or thirteen spines and sixteen soft rays in the back fin, three spines and twelve or thirteen soft rays in the anal fin. The body is covered with numerous small bronze spots sometimes confluent into lines.

The three species of the Porgy family which occur here are readily separable by color. The largest, the Sheepshead, at any age is marked 
with broad bold vertical bands of black. This species grows rather commonly to weigh six pounds, and occasionally weighs twenty. In the Sailor's Choice, the sides are striped lengthwise with silvery blue and pale gilt. There is a black spot on the shoulder and several more or less distinct dark vertical bands not as bold as those of the Sheepshead. In the Porgy the color is brownish, somewhat silvery below, with bright reflections everywhere and with no distinet markings, though there are sometimes vague dark cross shades. The Porgy is one of our most abundant small marine fishes, rather deep bodied and compressed the spiny and soft rayed hack fins eontinuous, the tail fin lunate and the

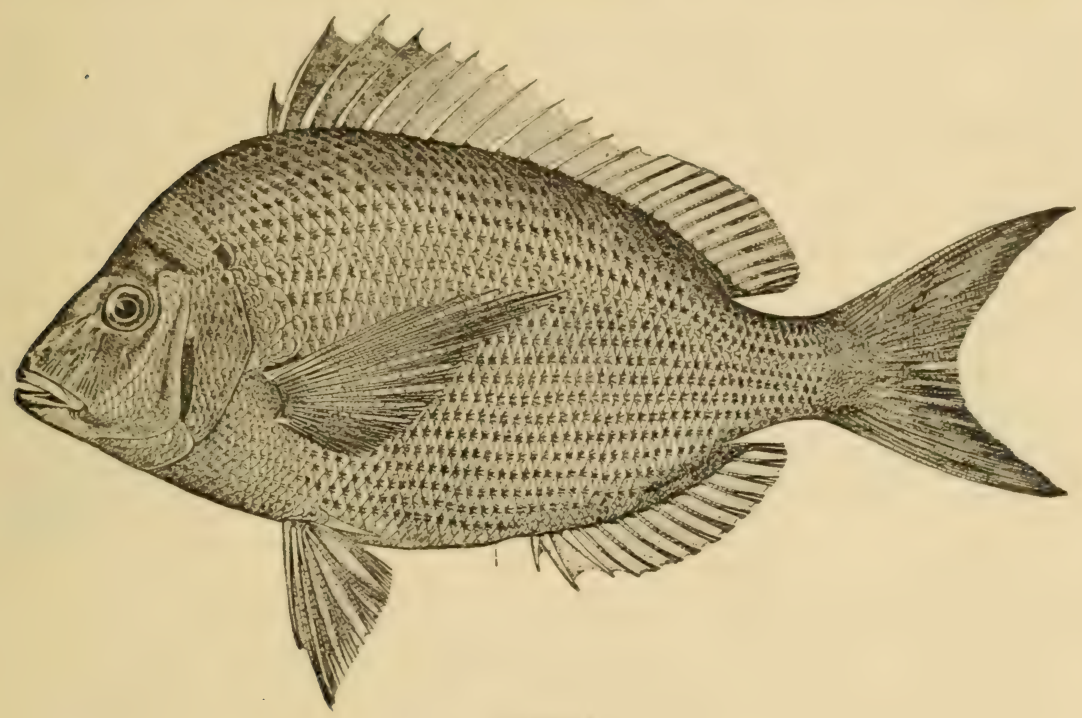

PORGY

pectoral fin long and pointed. It is taken in inshore waters from April to November. The Sheepshead is of regular occurrence here though not abundant, and the Sailor's Choice, a small fish which might readily be mistaken for the Porgy, is only an occasional visitor from the south though at times caught in fair numbers.

The Weakfish, Drums or Croakers are a family characteristically found on sandy shores in moderate latitudes. They have no incisor or molar teeth in the mouth and the opercle or gill-cover usually ends in two flat spines as in the bass. The anal fin is preceded by one or two spines, never more than two, wherein they differ from the other families 
considered in this chapter, which have three. The tail fin is usually not forked and the snout has the tendency to project beyond the mediumsized mouth, although in some of our species it does not do so. The lateral line extends onto the caudal fin, one of the chief "earmarks" of the family. Most of them are readily reccgnized as such by a person familiar with them, but not so with some of the less typical forms of which the Weakfish is one. Many of the species make grunting sounds, whence the names Croaker and Drumfish. The very large otoliths or ear bones which they possess may bear some relation to these sounds.

Eight species of the Weakfish family occur in this vicinity. They are elongate fishes with a deep notch between the rather weak spiny dorsal and the soft rayed fin behind it, but the two may be joined at the base. The Weakfish has a large mouth, the lower jaw extending distinc:ly further forward than the snout, and its tail fin is slightly emarginate behind. It is a gracefully formed fish abundant during the summer

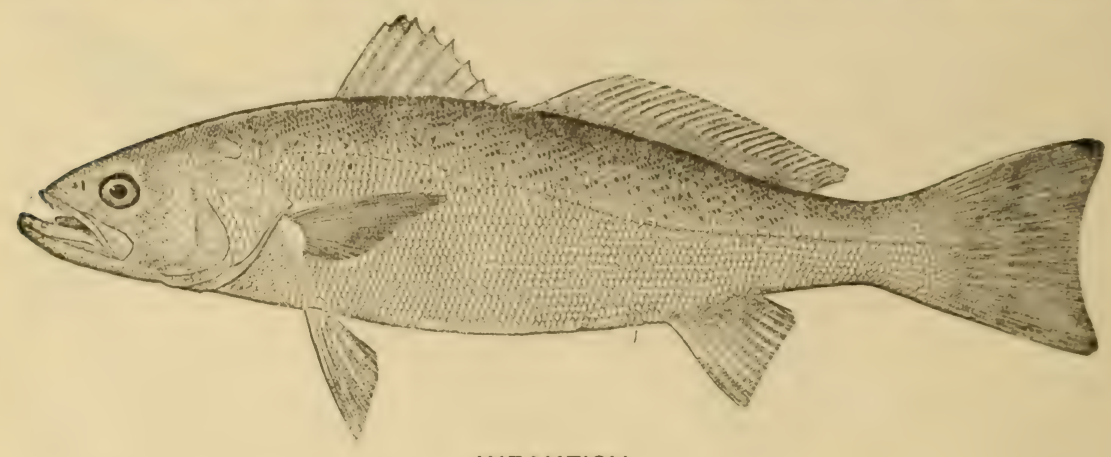

WEAKFISH

months and sought for sport and food. It is silvery in color with iridescent reflections, dark above and marked with many small irregular dark blotches, the whole effect being that of lacking any bold pattern.

The Weakfish is the principal salt-water game $f$ th pursued with rod and line by dwellers of New York City. Straggling Weakfish usually reach our waters in May, but the middle of June has generally arrived before they appear in abundance, the time of their appearance being dependent on whether the season is an early or a late one, and the corresponding temperature of the water. For days before the Weakfish come some of the most enthusiastic fishermen have been going out diligently to find them, and the first schools are welcomed with enthusiasm by the angling fraternity who at once take to boats in their pursuit. 
The baits most in favor for Weakfishing are white worms and shedder crab. Sometimes the white worm bait is topped with a live shrimp impaled on the very tip of the hook, and shrimp are frequently used as "chum" to lure the fish about the boat.

When large Weakfish become very abundant off the ocean beaches, as they frequently do, sailhoats cease trclling for Bluc fi:h, lie in the wind, and fish for the "Weaks," with metal Bluefish "squid," in a minter known as "jigging." The "squid" is lowe:ed to nexr the bottom, and at intervals lifted rapidly through a foot or two of water and allowed to drop back again.

Inshore. school Weakfish do not average over a pound in wcight. Offshore, they run larger, five or six pounds being common, and ten pounds not very rare. Thirty pounds has been reachel by the species.

The Banded Croaker is a rare straggler to our shores in summer. It may be recognized by the peculiar form of the mouth which is almost vertical, opening upward instead of forward. The back has several rather conspicuous dark bars which extend to below the middle of the sides. The Silver Perch is a southern species occasionally common here in late summer and fall. It is a small compressed fish with the head rather pointed, slightly concave over the eye, the mouth somewhat oblique, though horizontal rather than vertical. It is silvery in color with yellow fins.

The Channel Bass is an elongate fish with a strictly horizontal mouth and the lower jaw not extending as far forward at the upper. Its tail fin is evenly truncate with a conspicuous oval black blotch at its base above. Occasionally there are two blotches. Channel Bass reach a length of two to five feet and a weight of seventy-five pounds and furnish excellent sport, being frequently angled for through the surf. The large ones, over 15 pounds, are coarse and not very good eating. They are rare in this immediate vicinity but common further south on the New Jersey coast. The Spot or Lafayette is a small fish with a high, bluntly rounded snout, extending slightly forward of the tip of the lower jaw. It has a distinctly although not deeply forked tail and a conspicuous blackish spot on the shoulder; further back narrow dark lines extend downward and forward from the back. At intervals of several years Lafayettes become excessively abundant about New York and may be caught in numbers from piers along the city's waterfront. A few 


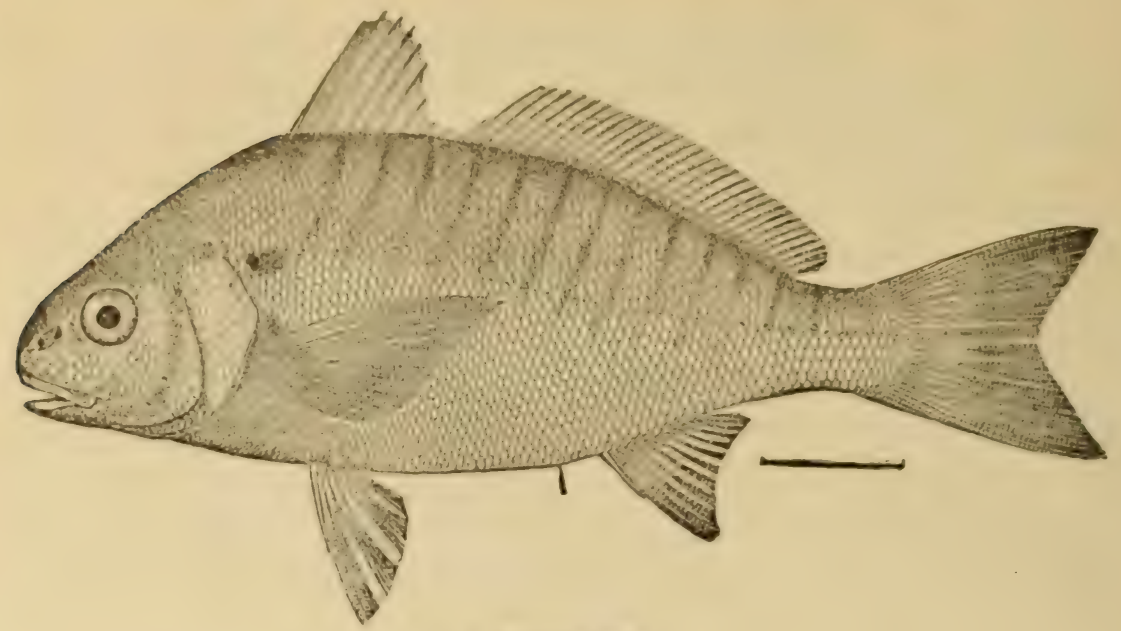

LAFAYETTE

may be found in this vicinity any summer. The Croaker is a fish with a superficial resemblance to the Weakfish but is somewhat smaller. Occasionally it is eaught here in fair numbers, when its habits are much the same as those of the Weakfish with which the less intelligent fishermen confuse it. Its mouth is distinctly smaller, however, the snout more rounded and conspicuous, extending if anything, slightly beyond the tip of the short lower jaw, and the central rays of the caudal fin are the longer. Furthermore it has several small barbels on the chin. Barbels are rather characteristic of this family but the Croaker is the first species that we have considered which possesses them. The Kingfish has the spiny back fin relatively higher and more pointed than in the other species. The snout is pig-like and projecting. The lower jaw is short with a single fleshy barbel, the tail fin evenly rounded, and there are rather bold well marked dark bars extending downward and forward across the fish's sides. The Kingfish is common on sandy ocean shores and is frequently taken by casting through the surf, as is the larger Striped Bass. It averages two or three pounds in weight, grown fish being from one to six pounds. The last of the family, the Drum, has a large strong spine preceding the pointed anal fin, and broad black bands across the body suggestive of the Sheepshead, whereas numerous threadlike barbels hang from its chin, which are much longer and more conspicuous than those of the Croaker. Its tail fin is square, and, especially in large fish, which lose the black bands more or less, the form is chunky. 
The Drum reaches a very large size, sometimes weighing over a hundred pounds. Although no fish of this family has molar teeth in the mouth, the Drum has very broad flat-crowned molar teeth on the bones of the throat. These tooth-bearing throat bones frequently excite the interest of persons finding them along the shores and are sent to the Museum for identifieation. They are said to be used by the Drum in crushing shellfish, and this species is reputed to be destructive to oysters. This fish reaches a very large size, those of fifty to eighty pounds not being rare, and there is a record from Florida of an 146-pound example. It is taken on the New Jersey coast by casting through the surf.

All the fishes of the Weakfish family are excellent as food, except that large individuals of such large species as Channel Bass and Drum have a coarse flesh which is sometimes wormy. Small forms like the Silver Perch, Lafayette, Croaker and Kingfish are particularly delicate in flavor, although the Kingfish is the only one that has a local reputation as a table fish.

\section{Mackerel-Like Fishes} (Scombriformes, etc.)

These are carnivorous species of free-swimming habits. All have deeply forked tails and narrow firm peduncles, an arrangement best suited for propelling the fish at a rather high speed through extensive stretches of open water. The eight species of true Mackerels are characterized by pointed, more or less cigar-shaped bodies, a first dorsal fin of weak spines depressible in a slot in the back, and the soft dorsal fin and anal fin below it are short with a number of isolated finlets between them and the tail. The snout is pointed and of one solid piece so that the upper jaw is not capable of being thrust forward. In the Mackerel and Chub Mackerel there is no central keel on the caudal peduncle, although there are two small keels obliquely placed, one at the base of each caudal lobe. These two species resemble each other very closely but the Chub Mackerel has nine or ten spines in the first dorsal fin instead of eleven or twelve as in the Mackerel. In adult Chub Mackerels the lower part of the side is mottled instead of plain silvery, and the eye is distinctly larger than in mackerel of the same size. There is also a translucent area on the snout much more conspicuous than that in the Mackerel. The Mackerel schools occur offshore in spring and summer and young ones are regularly taken in inshore waters in fall. The Chub Mackerel is of irregular occurrence and abundance in summer. A full-grown Mackerel averages about a foot long and weighs about a pound. 
Occasionally they reach a length of about twenty inches and a weight of about three pounds and a half. The remaining six speries have a strong central peduncular kecl. The Oceanic Bonito and the Little Tunny have the skin of the body without scales except for a few small ones along the latcral line, and large scales fused to form a corselet in the thoracic region. 'I he Oceanic Bonito has four lengthwise dark stripes on the side of the borly below the lateral line, whereas the little Tunny has a number of irregular dark stripes on the posterior part of the back and usually a few oval black spots on the lower side. Both species, though offshore fishes of tropical seas, oceasionally straggle to us in late summer or early fall. The Oceanic Bonito is one of the pelagic species most frequently met with in the broad trade-wind belts of all oceans where it roams in small hungry schools preying on the flying fish, which there are the abundant, conspicuous and characteristic form of fish life.

The remaining four mackerels have the body covered with small scales. The Spanish Mackerel is very different from the other three in that its body is more elongate, compressed, with scattered oval yellowish spots, lacking entirely the corselet which is present in the Tunny, Albacore and Bonito which approach the Oceanic Bonito type. New York is near the northern summer limit of the Spanish Mackerel's range but it is frequently common here in late summer having at that time much the

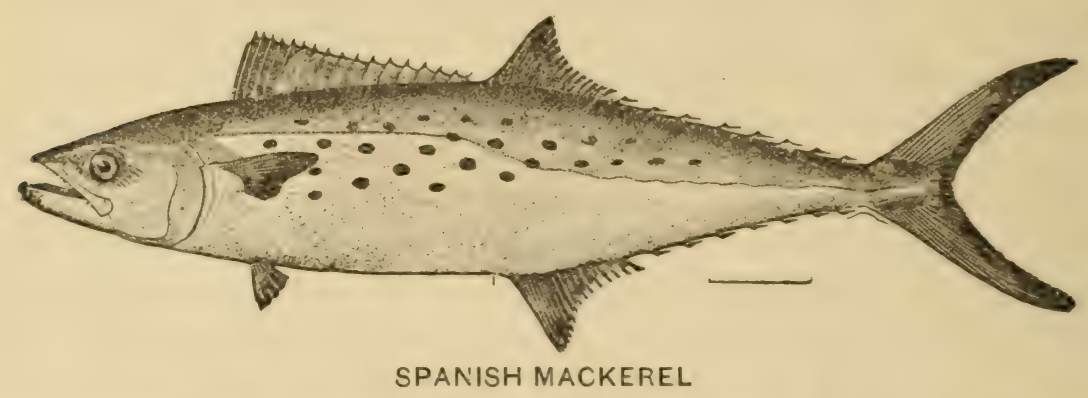

same habits as the Bluefish. Its flesh unusually rich and sweet, the Spanish Mackerel is justly famed as a tab!e fish. This species sometimes occurs off our coast in fair numbers and is taken while trolling for Bluefish. Grown fish weigh from six to ten pounds. The Albacore can always be recognized by its very long ribbon-shaped breast fins but the Tunny and the Bonito have no readily appreciable superficial difference save that of size. The Tunny is large, at times enormous, reaching a length of 
ten feet or more and a weight of fifteen liunded pounds, whereas a Bonito of ten or twelve pounds is of unusual size. The color markings of narrow dark stripes running oblicuely downward and forward on the back and sides distinguish the Bonito from similar fishes. Our knowledge of the occurrence of Albacore and Tunny is limited. Of irregular appearance with us in summer, doubtless both species are at times more or less common offshore. The Tunny has long been the object of extensive fisheries in the Mediterranean and is the Tuna of California sportsmen. The Bonito, on the other hand, is one of the most abundant offshore summer fishes near New York with habits similar to these of the Bluefish. From its custom of leaping clear into the air and then falling back into the water again, it has been given locally the name "Skipjack."

Swordfish, Sailfish and Cutlass Fish are unquestionably related to the mackerels but of a very un-mackerel-like appearance. The great Swordfish has the upper jaw prolonged into a flattened bony sword which structure alone will distinguish it from any other fish. The species doubtless occurs in summer with more or less regularity though there are no Swordfish grounds in this immediate vicinity. The maximum weight of the Swordfish is 600 to 800 pounds, though it is usually smaller, 400 pounds or less. The Sailfish is another large species with a somewhat similar but cylindrical instead of flattened bony extension of the upper jaw. It also has the spiny back fin greatly enlarged, extending almost the entire length of the back and rising high above it. When the fish is swimming at the surface this fin projects into the air and is even said to function as a sail. The Sailfish is a southern form only accidental with us. The silver Cutlass Fish is a third very different species. It is a rare straggler in late summer from the south, a band-like, elongate fish a foot or two in length, with large eyes, a formidable mouth, a low fin extending the .entire length of the back, and a finless tail ending in a thread-like process.

The Pompanos are a large family of fishes, mackerel-like in habit and apprarance, whose true relationship to the mackerels is somewhat doubtful. They characterist:cally have the ssales small and inconspicuous except for those on the posterior portion of the lateral line which are often enlarged and heavily keeled. The first dorsal fin is short, of weak spines, situated just in front of the longer soft-rayed second dorsal. The Gascon has the entire lateral line with enlarged keeled scutes instead of merely the posterior part of it. It is an European fish accidental on our coast. The Scad is another small species which may be recognized 
by the presence of a single mackerel-like finlet behind the second dorsal and the anal fins. This species as well as the Goggle-eyed Scad has the scutes rather weak and restricted to the posterior portion of the lateral line. The latter has very large eyes and may be recognized by a deep cross furrow in the shoulder girdle above which is a fleshy projection. These structures may be seen by lifting the gill-covers. Both Scad and Goggle-eyed Sead are sometimes numerous in summer though of irregular occurrence. The Jackfish and Hardtail are somewhat larger species. The breast in the former is without scales except for a small central

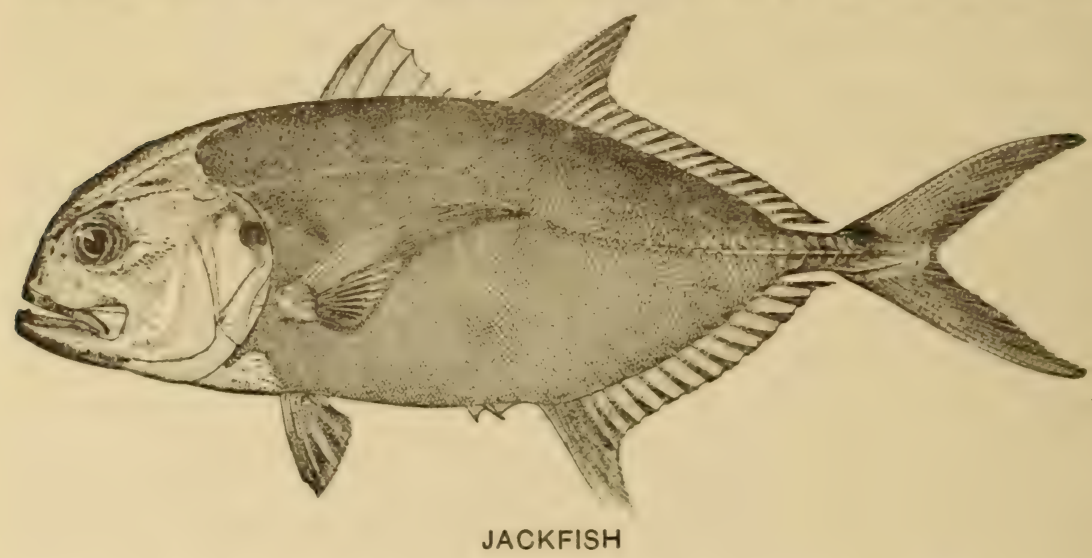

patch. There are about twenty-five scutes, and there is usually a round black spot on the basal portion of the pectoral fin. The Hardtail has about forty scutes and the breast is completely covered with small scales. The Jackfish is tolerably common in late summer and autumn and the Hardtail of similar occurrence though in less abundance. The Bumper is a somewhat similar fish but with the scutes so little developed as to be scarcely evident. It is very much compressed with the lower outline markedly more curved than the upper. This gives it a peculiar appearance and will facilitate its recognition. The upper part of its caudal peduncle is dusky in color which often makes a rather striking mark. Allied to Jackfish and Hardtail are three species of very much flattened, small, silvery fishes, a few of which reach our waters each summer or autumn from the south. The specimens captured are usually small, often no larger than a silver dollar. Those of the Moonfish have short fins whereas the Lookdown has at least two streamers from above and below, the lobes of the soft dorsal and anal fin being thus produced in the adult, whereas the young also have one or two of the dorsal spines 


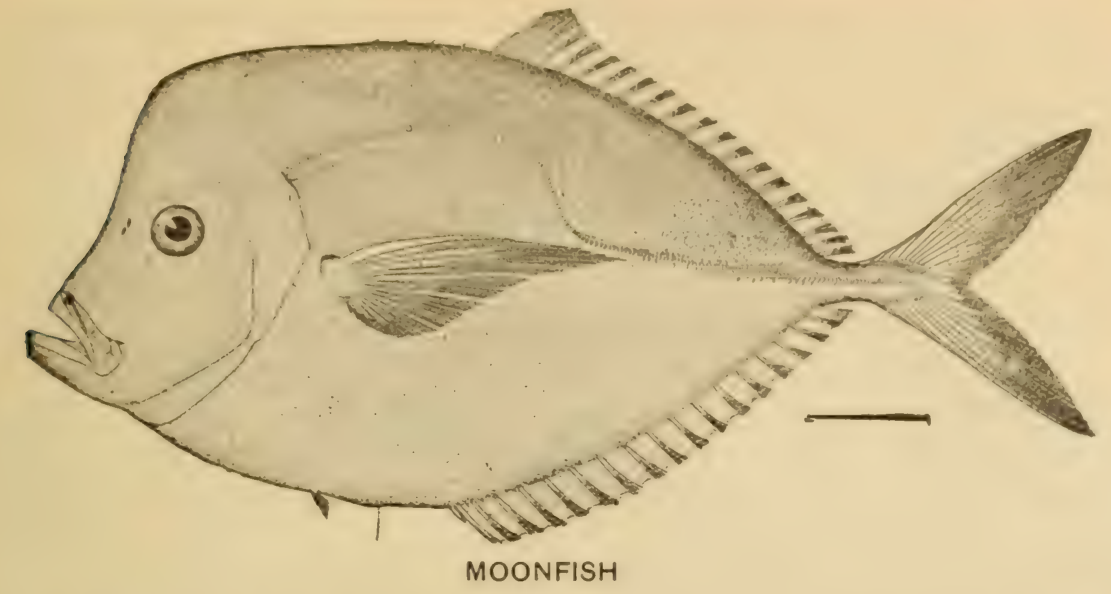

and the ventral fins elongate. The Lookdown has the anterior profile almost vertical, the distance being excessive from its nape to the mouth below. The third species, the Threadfish, is rather circular in outline with dark bands on the sides, the anterior rays of dorsal and anal fin indefinitely prolonged into thread-like lashes.

Aside from those already mentioned, six species of this family have a place in our local fauna. The Leatherjacket can be recognized by its peculiar very silvery hide marked with short longitudinal grooves formed by the fusion of its scales. It is perhaps the most markerel-like in the

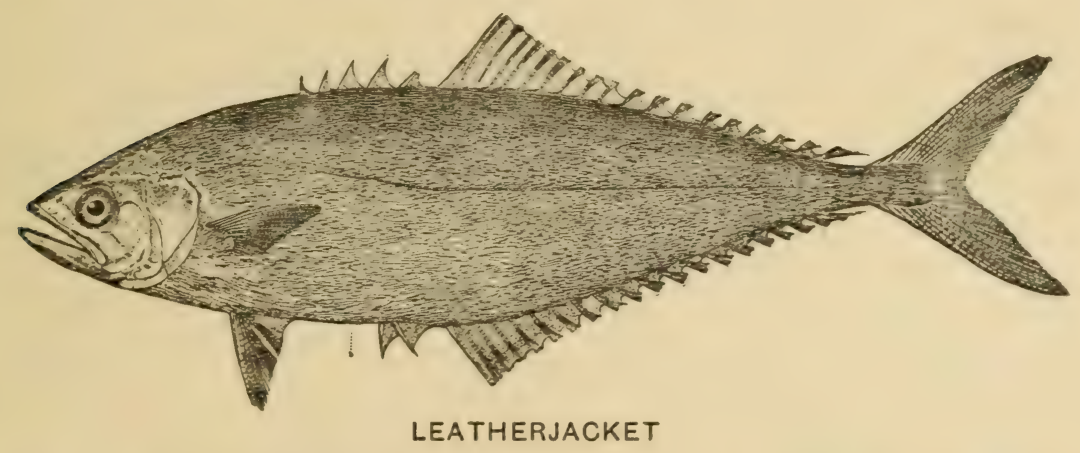

family. The posterior rays of its dorsal and anal fins are isolated resembling a mackerel's finlets and are merely connected at the base by a low membrane. It is a small species occurring occasionally in summer. The Runner, of accidental occurrence here, is a large offshore 
fish rescmbling the Scad in the single detached finlet before the tail above and below. It is not only much larger than the Scad, but lacks as well any indication of scutes on the posterior lateral line. The Runner is a brightly colored fish, bluish above, yellow below and on the tail, with two conspicuous blue lengthwise bunds on either side of the body.

The Banded Rudder Fish is tolerably common with us in summer and fall, a trimly built species generally a few inches long, swimming in small schools with a tendency to follow boats or to linger about buoys or drifting logs. It sometimes accompanies inshore sharks much as a related Pilot Fish accompanies those further out to sea. The numerous bold black bands crossing its body and fins make recognition easy. The head is shapely and pointed, the mouth of moderate size and the entire borly covered with small smoth scales. The tail is of the typical, forked, mackerel character and the peduncle before it is narrow and firm. The related Amber Fish or Amber Jack, which is of accidental occurrence near New York in late summer, reaches a much larger sizo, sometimes weighing as much as a hundred pounds, and it is generally without bands although the young are banded like the Bandel Rudder Fish but more narrowly. The Banded Rudder Fish has thirty-six to thirty-eight rays in the dorsal fin, the Amber Jack thirty to thirty-four. In the Pompanos, two species of which are tolerably common here in late summer and autumn, the scales are reduced and inconspicuous. The mouth is small, the snout region vertical and rather elevated, giving them a peculiar appearance which makes recognition easy. The very young have a well defined spiny fin in front of the soft dorsal but this becomes less conspicuous as the fish mature, leaving only a few low spines scarcely rising above the level of the back. The Round Pompano has only nineteen or twenty soft rays in the dorsal fin and is deep in body, the depth being contained about one and three fifths times in the length to the base of the tail whereas the Common Pompano has twenty-five to twenty-seven dorsal rays and the depth in the adult is between two and two and one half. This latter is a delicious and important food fish of the south, but grown Pompanos are almost unknown here, those that reach us annually being almost without exception young.

The remaining six species are of questionable relationship not only to the mackerels and pompanos but to one another as well. The Bluefish is pretty sur aly mora cl saely allied to the bas:, but its cce in life and wanderings have given it a contour strongly suggestive of, for instance the Jackfish. Its spiny dorsal fin is very small and weak, its tail fin an 


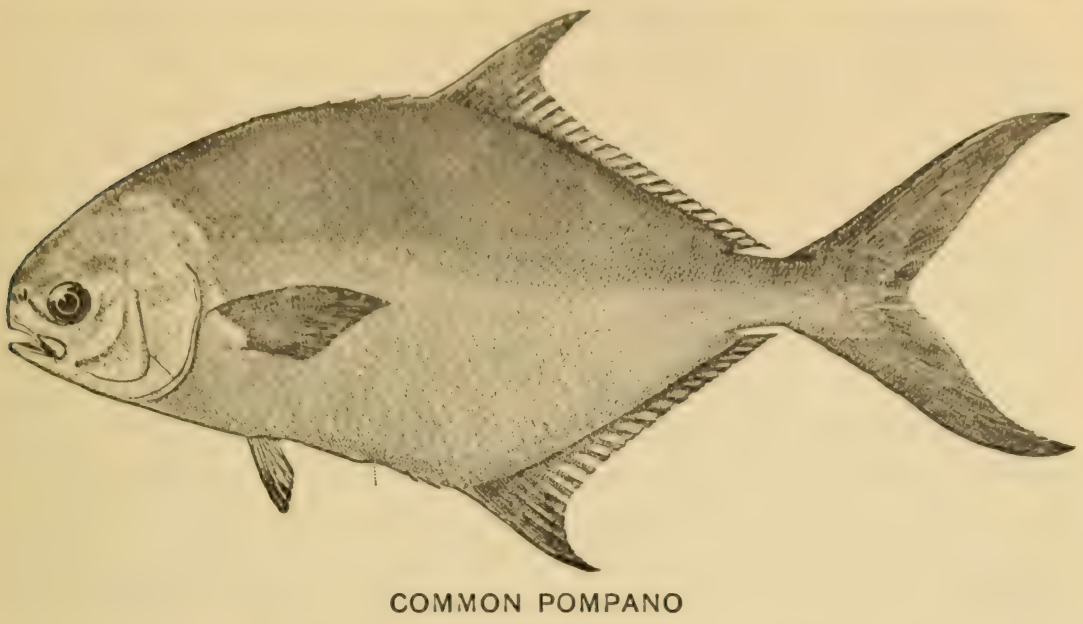

approximation of the very firmly forked mackerel type. The scales are small and slightly rough (ctenoid), which indicates that the Bluefish is not closely allied to the Jack Fish. It is an unusually symmetrical fish with large mouth and projecting lower jaw. Bluefish schools occur in the Indian Ocean as well as in the Atlantic but are not known in the Pacific. The fish's stay with us is confined to the warm months though it may be found further south on the coast throughout the winter. It is tremendously destructive to smaller species, especially to the schools

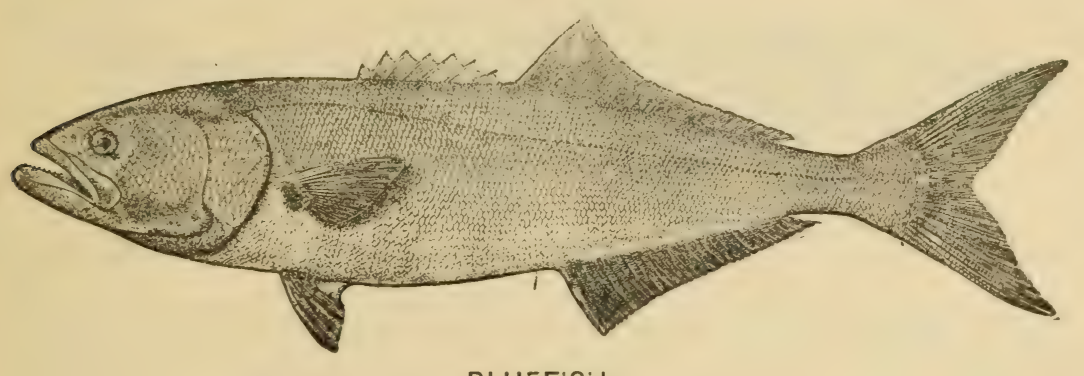

BLUEFIS:-1

of Menhaden. It grows rapidly and furnishes exceptionally fine food as well as sport. The Bluefish is the salt water species which can preeminently be taken by trolling with a shiny metal "squid" in place of any bait. In late summer and fall the young of the Bluefish known as "Snappers" furnish excellent sport on light tackle in in-shore waters. 
Bluefish are taken commercially by lines more than by nets to which they are very destructive. There is a fishing ground near Sandy Hook where a great many are taken by chumming with hand-lines from boats. One man is kept busy grinding Menhaden and throwing it overboard to form an unbroken strip of chum, cutting the back from each Menhaden as he does so, to serve as a bait. The others haul in the Bluefish, which work up through the chum, hand over hand, about as quickly as they can bait and throw over their lines. It is strenuous work for the crew, who are exhausted after about two hours of it. Finally, when tired out or when the fish suddenly stop biting, one of the boats starts back to the city, and they all follow, racing to get to market before the catch shall have sent down the price of fish.

Adult Bluefish are taken by trolling with metal "squid," largely from sail boats. The larger ones occur off shore, smaller ones in the bays. Though their game qualities may be superior, they are accessible to a far smaller number of city anglers than the Weakfish.

Early in the season off shore Bluefish average about six pounds in weight. Later, ten-pound fish are not unusual. A century or more ago they are said occasionally to have been taken up to forty or fifty pounds.

The Crab-eater is a southern fish whose young occasionally straggle north to New York in summer. It is an elongate species with the forked

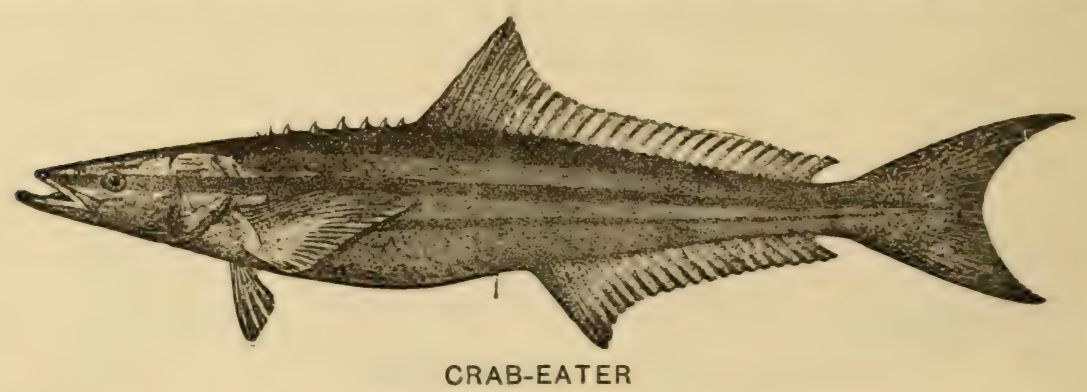

tail not so symmetrical and firm as in most of those we have been considering. The head is slender with projecting lower jaw and the dorsal fin consists of several low isolated spines on the back, in front of the rather long soft dorsal. The Crab-eater has one or more dark stripes the length of its body which will aid in its identification.

All the fishes we have considered in this chapter have a more or less off-shore, free-swimming habit, but with the possible exception of the Oceanic Bonito, the Dolphin is more truly pelagic than any of them. 
This fish is perhaps the swiftest that swims the seas. $\Lambda$ thousand miles of azure sea before it, a thousand miles of azure sea behind, it slips through the water swift and deadly as a brilliant colored knife; and any flying fish in its path slow in gaining the air, promptly changes from incentive to motive power.

The Dolphin is elongate in form tapering gradually from the shoulder to the tail. A long rather high fin composed entirely of slender flexible spines runs the entire length of the back, and adult males have a very high, thin vertical forehead. It is one of the most brilliantly colored and changeable fishes; vivid blues and yellows run across the sides of a living example like the shadows of clouds. It grows very large, often reaching a length of five or six feet. It associates in small schools which prey almost exclusively on the flying fish, and is frequently caught from deep-water sailing ships on a hook set in a piece of wood over which a white rag is draped. This lure is barely allowed to touch the water and then jerked into the air again, and doubtless simulates a flying fish to the eye of the Dolphin below. Sailors say that the flesh is sometimes poisonous and should be cooked with a piece of bright silver. If the silver stays bright, that particular fish can be eaten. Considerable confusion seems to have existed for a long time in regard to the word dolphin which is used almost exclusively for porpoises except among deep sea sailors, where it is applied only to this fish. The figures of dolphins on the old Greek coins are of the porpoise, and the dolphin of heraldry was a combination of these two unlike marine creatures, of ten with tusks indicative of the porpoise's resemblance to a pig, but with the long spiny fin on the back characteristic of the fish. Very small Dolphins hide in drifting weed or about floating wreckage and have a mottled white and yellow concealing color.

The Rudderfish is a small or medium sized species found off-shore about drifting logs or other wreckage. It is blackish in color with a rather small mouth and the head very blunt and rounded in front. As in the Crab-eater, the spiny dorsal fin consists of short stout isolated spines, six or eight of these being present. Dolphin and Rudderfish are both rare stragglers to this vicinity in late summer and fall. Related species are the Harvest Fish and the Butterfish, small, silvery, with small mouths and no ventral fins. The dorsal and anal fins are rather long and almost identical in size and form. In the Harvest Fish the dorsal and anal fins have pointed, excerted, anterior lobes, and the body is so deep as to be almost circular in outline. The Harvest Fish is occa- 


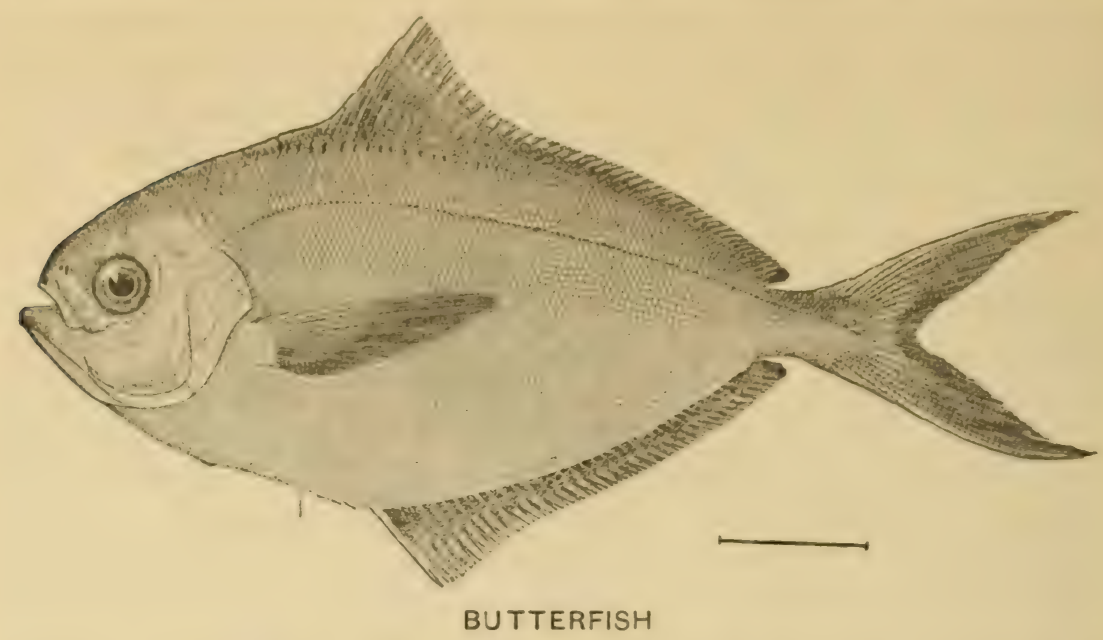

sionally common in summer, the Butterfish abundant, occurring in summer and especially in fall when it may be found swimming along sandy beaches in the surf, frequently partilly stranded by a breaking wave. It sometimes may be captured by following the receding breakers and sconping it from the sand with a crab net before the next wave enables it to make its escape. This fish attains an average size of seven to eight inches, and is taken in very large numbers by net and trap fishermen.

\section{The Blackfish, Angelfish, "Blowfish" and others} (Perciformes to Plectognathi)

In this chapter we start with fishes of somewhat perch-like form and end with a very un-perch-like series, through round, sluggish fishes to the great grotesque Mola or Headfish, one of the strangest forms of sea life.

The Bergall is a small, perch-like, marine fish with a special liking for rocky shores, and although its range extends southward as far as New York, it is probably for this reason not as common here as on the coast of New England. Its mouth is rather small and its anterior teeth peculiar and canine-like. This will serve to identify it taken in connection with the numerous (about eighteen) spines in the back fin, which are about equally high with the short connected soft-rayed fin which follows them. The tail is rounded, the pectoral fins rather broad and 


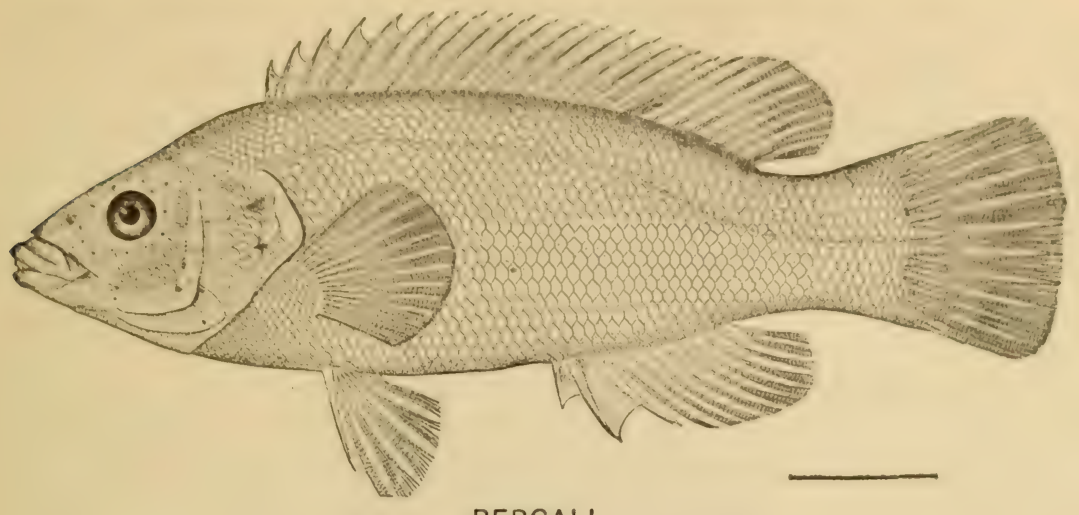

BERGALL

fan shaped. When swimming slowly, the pectoral fins are often the propelling power, the body gliding forward smoothly and rather swiftly. This is a sort of locomotion rare among fishes and characteristic of the Wrasse family, of which the Bergall is the most northern representative on our coast.

It would be an excellent food fish except that it does not reach a large enough size. In consequence, where abundant, it is a nuisance to fishermen. It is sometimes called Nibbler. Northward along the New England coast it is known as Cunner. Here it reaches a somewhat greater size and is largely taken in traps and extensively used for food. The Bergall is ordinarily less than a foot long and weighs under a pound. In this latitude it is generally much smaller, the large ones being more northern in distribution. Two-pound fish are said to have been taken.

The Blackfish or Tautog is a close relative of the Bergall from which it may be readily distinguished by its deeper body, the depth to the base of the tail being contained somewhat less rather than somewhat more than three times in the length. Its scales are also decidedly smaller, there being about sixty in a lengthwise series instead of in the neighborhood of thirty-five. The Blackfish grows much larger than the Bergall and is one of the most valuable food fishes of the Atlantic coast, being much sought after by local anglers. The largest Blackfish on record was taken near New York in 1876. It was thirty-six and one half inches long and weighed twenty-two and one half pounds. This size is, of course, very exceptional. Anything over ten pounds is very large for the species. 
We now come to several deep-bodied flattened (compressed) fishes which straggle to New York waters from the south in summer or autumn. Perhaps the commonest is the Spadefish which sometimes reaches a length of two or three feet. The body, which is covered with fine scales, is as leep as its length or two thirds as leep. It has a small first dorsal fin of heavy spines and large falcate second dorsal and anal fins covered with scales; the tail is somewhat crescent shaped. The Butterfly-fish

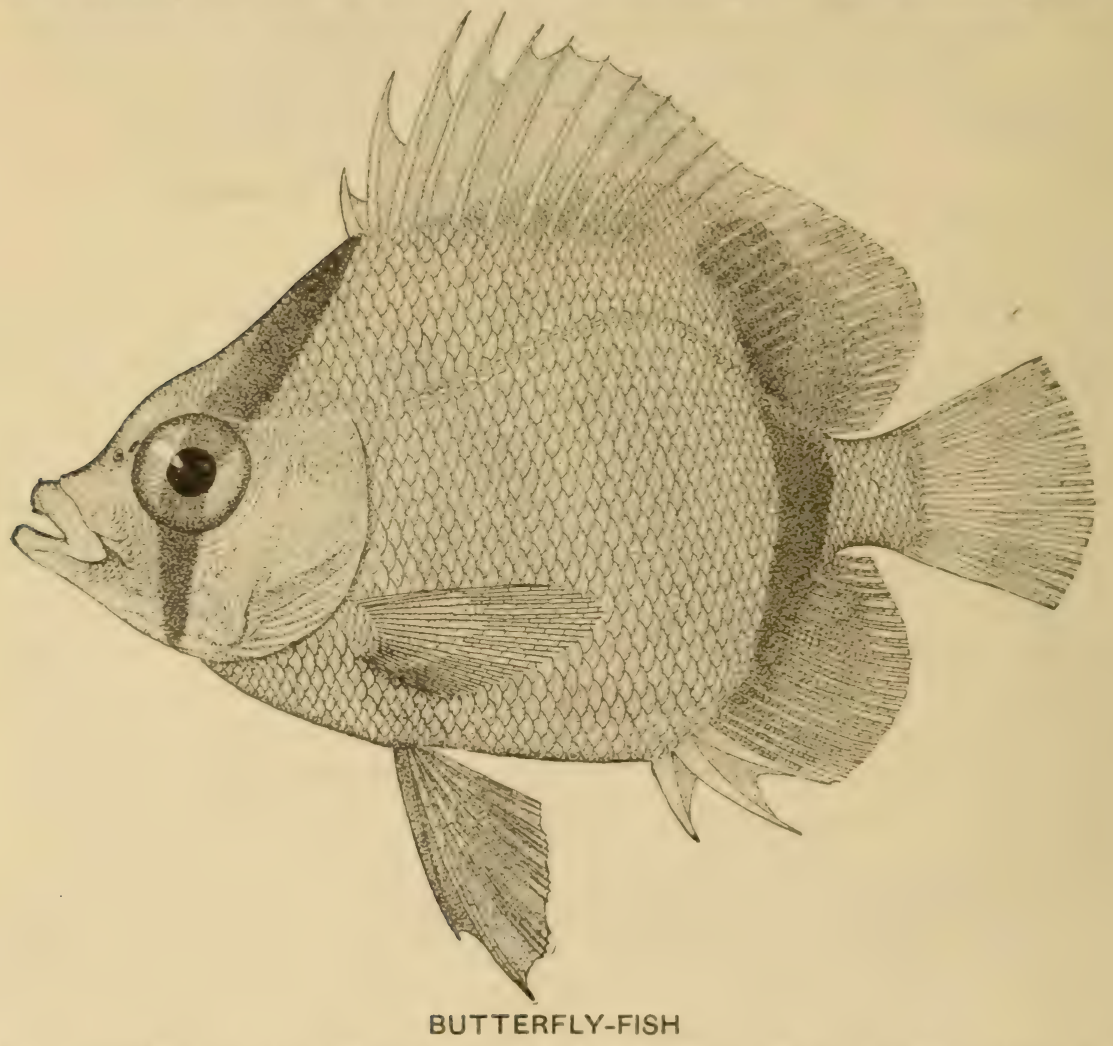

is a smaller species, the young of which, often only an inch or two in length, straggle to our shores. In a general way, it resembles the Spadefish, but the spiny part of the dorsal is continuous with the soft part, and the soft part of dorsal and anal are not produced in pointed lobes. the tail fin rounded. It is marked by two bold black stripes; the first extends downward from the front of the dorsal fin through the large eye across the cheek, the second from the soft dorsal fin downward across the posterior part of the body to the anal fin. 
The Black Angelfish is another of these compressed, deep bodied forms and has a very strong spine at the lower angle of the pre-opercle. Among the small seales on the body still smaller ones are distributed so that the series are not distinct. Dorsal and anal fins have pointed lobes and the caudal is rounded. The spines in the front of the dorsal are of ten quite hidden in the sealy membrame of the fin. Adults are blackish in color, the young with light colored crescentic cross bands.

The Doctorfish is a very fine-scaled compressed form with dorsal and anal fins with even margins, that is, not pointed or divided. The spines in the front of the former are rather weak. It has a peculiar crectile spine on either side of the peduncle (the tail end of the body behind the axils of dorsal and anal fins). The Triggerfish, sometimes called Leatherjacket, has a very small mouth with incisor teeth forming a rather beak-like arrangement. The ventral fins are reduced to a single central spiny process. The skin is very heavy and leather-like, but the scales distinct on it. The first dorsal fin is represented by three spines joined in membrane, the first the highest, very strong, the second locking it when erect.

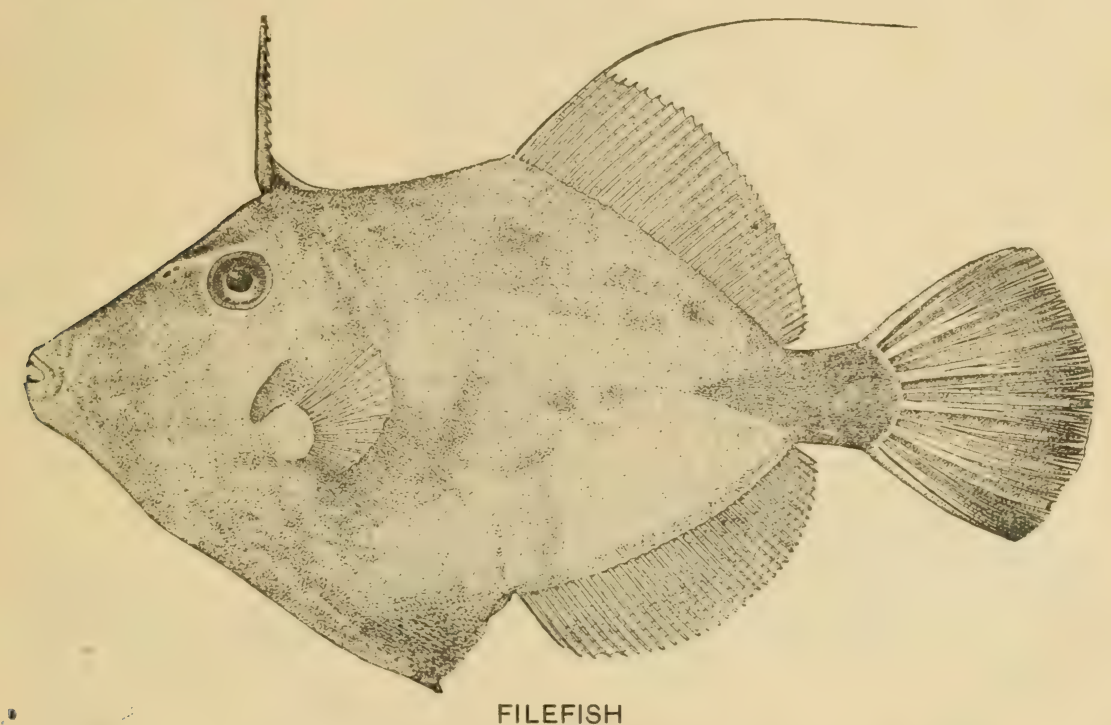

Through the Doctorfish and Triggerfish we have approached the Filefishes, two species of which are tolerably common here in summer and autumn. They resemble the Triggerfish somewhat but have a single isolated spine only on the back and lack evident scales. In the 
Filefish there is a small ventral spine like that of the Triggerfish. The Orange Filefish and Unicorn Filefish lack this structure and their bodies, particularly the tail part, are more elongate. The Orange Filefish has about thirty-six rays in the dorsal fin, the Unicorn Fish about forty-six. The latter is the rarer member of the trio, the records from hereabouts being very few and rather unsatisfactory.

A still further development along this line is the Trunkfish whose body is encased in a hard, three-cornered, beech-nut shaped shell. Only one species of Trunkfish is recorded as straggling north to us in summer and autumn. This is the Common Trunkfish which has distinct spines extended backward from the ventral region behind, no spines in front of the eye and the shell closed behind the dorsal fin. There is evidently rather a close relationship between the Trunkfish and the Swellfishes

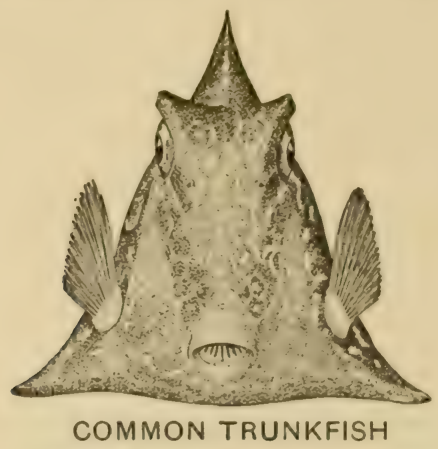

with loose skin, oblong bodies, small isolated soft-rayed dorsal and anal fins. These fishes have the power of inflating the body with water or air till it assumes an almost spherical outline. Our common species, the Swellfish or Blowfish, has dorsal and anal fins of six or eight rays, caudal

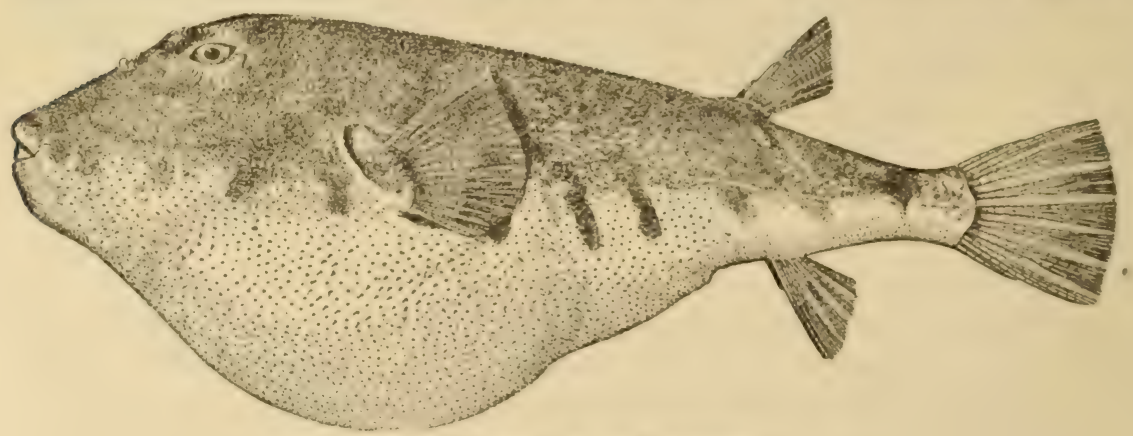

SWELLFISH OR BLOWFISH 
fin rounded or even, skin everywhere covered with fine prickles. A larger species which sometimes oecurs here, the Smooth Swellfish, has the dorsal and anal fins higher and more pointed with twelve to fourteen rays and a somewhat lunate caudal fin.

The Spiny Boxfish is in a way intermediate between the trunk and Swellfishes, being oval in shape, covered with skin, which is more or less backed up with a firm subcutaneous structure, and the body everywhere armed with short heavy seattered spines. This species is uncommon here in autumn though scarcely rare enough to be called accidental.

Probably the most peculiar of all this line of fishes and the one which is generally considered the most removed from the more conventional triggerfish type, is the Headfish or Sea Sunfish, a large species with small mouth and eye and leathery skin, deep compressed form, high pointed dorsal and anal fins, with practically no body behind them, the tail fin reduced into a long vertical fringe between their posterior axils. The pectoral fin is placed almost in the center of the side with the very small gill-opening before it. This creature looks like the head of some gigantic fish without any body behind it. It is a deep sea or pelagic species, reaching a large size, with very wide world range, and recorded once or twice from this vicinity.

\section{The Sculpin-Like Fishes}

(Loricati)

This chapter deals mostly with marine fishes with large spiny heads. Only one of our twelve species occurs in fresh water, the others are marine. The technical character which differentiates them from fishes in other groups is the extension backward of the third suborbital bone which forms a bony stay across the cheek.

The Blob or Miller's Thumb, locally common in some of the streams within fifty miles of New York, is our one fresh-water Sculpin. It is a concealingly colored fish given to lying on the bottom. It has a large depressed head and a moderately strong spine in the preopercle concealed except when the fish assumes a defensive attitude. The first dorsal fin of eight rather weak spines is followed by one with sixteen soft rays and there are twelve soft rays in the anal fin. We have three or four marine species of Sculpins proper. The Brassy Sculpin is uncommon here throughout the year, perhaps most numerous in the fall. The allied Mitchill's Sculpin, which may be only a phase of the other, is 
sometimes taken with it in the fall. The Hacklehead is very abundant in the colder months of the year and may occur occasionally at other

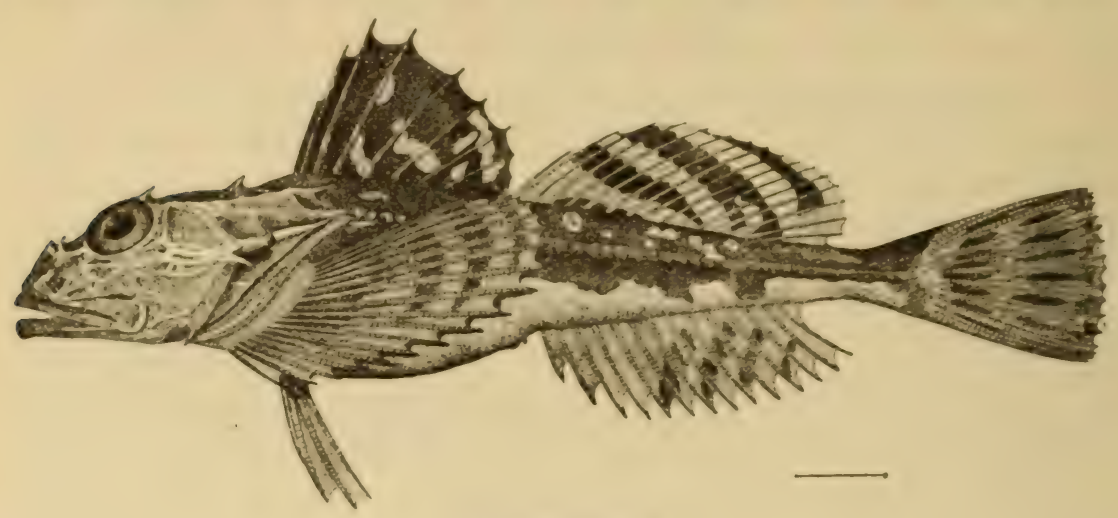

HACKLEHEAD

seasons, and the Daddy Sculpin, a northern fish, is supposed to be of occasional occurrence hereabouts although it is possible that the records are erroneous. All these species have large flattened heads, the lower jaw somewhat shorter than the upper, the preopercle with two strong straight spines and other spines also about the head, the body without any true scales. They are not at all valued as food, and yet what little is left of the fish when the inedible spiny head has been removed would probably be excellent eating.

The Brassy Sculpin and Mitchill's Sculpin have only ten or eleven rays in the anal fin and the spines about the head are rather short. The former is more or less brownish mottled in color, the latter is sharply marked with dark, almost black, and white. The Hacklehead has fourteen rays in the anal fin and its upper preopercular spine is very long, about four times the length of the spine below it, whereas in the Daddy Sculpin, this spine is only about twice as long as the spine below it. Both of these species have a rather sharply mottled dark and white color like the Mitchill's Sculpin and differ from the brownish tints of the Brassy Sculpin.

The Sea Raven is a fish similar in form to the sculpins, with the head less spiny, bearing numerous small flaps or tentacles, and the spiny dorsal fin very ragged in appearance. Its first three dorsal spines stand up above the others which are excerted beyond the basal membrane, and all the spines have short flaps near their tips. The Sea Raven reaches 
a length of eight inches and is usually reddish brown or yollowish in color. Another fish related to the sculpins is the Rosefish, a deep water species common northward and only of accidental oceurrence in our region. It has a somewhat spiny head, a long spiny back fin of fifteen spines joined to a shorter one with soft rays. The tail fin is small and coneave behind, the body covered with small seales, the lower jaw projecting decidedly beyond the upper, and the eye large, the color nearly uniform orange red, sometimes with vague dusky bars.

The Sea Poacher is another deep water fish which is allied to the sculpins, occurring accidentally in this region. It has a very slender elongate body terminated by a fan-shaped tail fin, a short head with a large eye, the small dorsal and anal fins similar and opposite to one another near the center of the fish's length, and the body covered with keeled bony plates.

The Lumpfish is a shore species which is rather uncommon. It has an unshapely somewhat globose form without scales but with the body sprinkled over with small tubercles and large tubercles forming lengthwise series or ridges. The fins are short and soft rayed. The fish is somewhat translucent and varies in color, from yellowish and brownish to greenish.

The Sea Robins are sculpin-like fishes with large pectoral fins which they spread horizontally in swimming. They have somewhat pointed bird-shaped heads which are completely encased in a covering of bone. Before each pectoral fin are three separate fleshy rays which the fish uses as tactile organs. Two species of Sea Robins are common in summer. The Carolina Sea Robin has a more or less distinct groove across the top

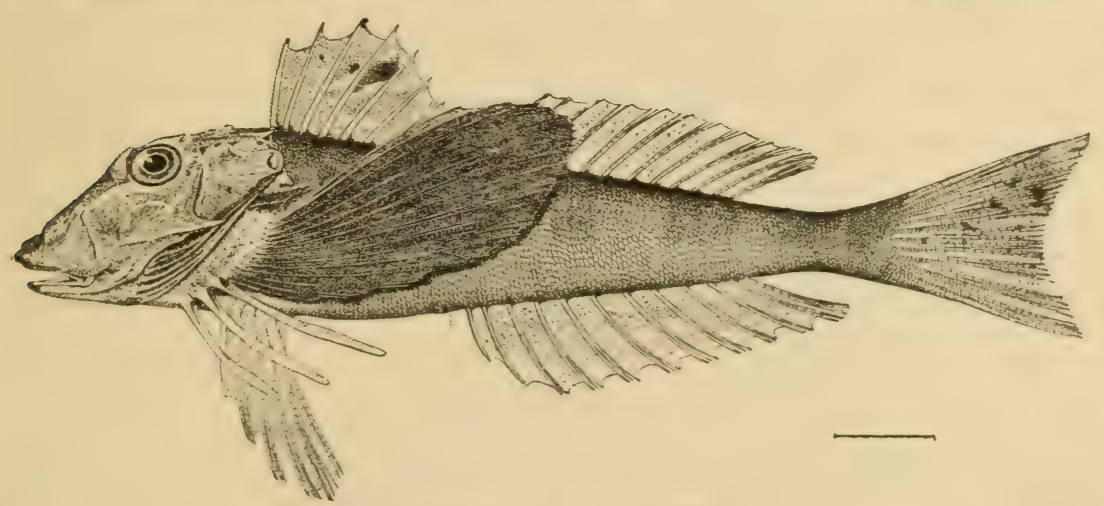

CAROLINA SEA ROBIN 
of the head behind the eye and the pectoral fin not quite reaching the midclle of the soft dorsal. The Striped Sea Robin, which is a somewhat larger fish, is rather pale brownish with a very distinct dark stripe below the lateral line and another parallel with it, which becomes broken posteriorly into a series of brown spots. This species lacks the cross groove on the top of the head. The Sea Robins make grunting noises when caught and perhaps communicate by similar sounds when under water.

The Flying Gurnard is a southern fish allied to the Sea Robins which is of occasional occurrence in our waters in late summer and fall. Its head is less pointed though similarly encased in mail and with a very long spine extending backward from the lower part of the gill-cover. The eye is large, the breast fins very long and when folded back reach about to the base of the tail. With their aid the fish makes long leaps above the surface of the water.

\section{Gobies, Blennies and others \\ (Gobioidea, Blennioidea, etc.)}

In this chapter we have gathered together several rather unrelated types of marine fish including only one true Goby, the Naked Goby. This is a very small fish without any scales, with a short blunt head and elongate body, the depth being contained five or six times in the length to the base of the tail fin. There are two separate dorsal fins, the first of seven weak spines and the second of about fourteen soft rays, and there are ten rays in the anal fin. It is a mottled olivaceous fish found hiding about the bottom, characteristically among seaweed.

Here we have also placed the "Remoras" or sucking fishes, flattened species which attach themselves to sharks and other large moving objects by a peculiar sucking disk with cross lamellæ, like the slats of a blind, situated on the top of the head. The common Shark Sucker has

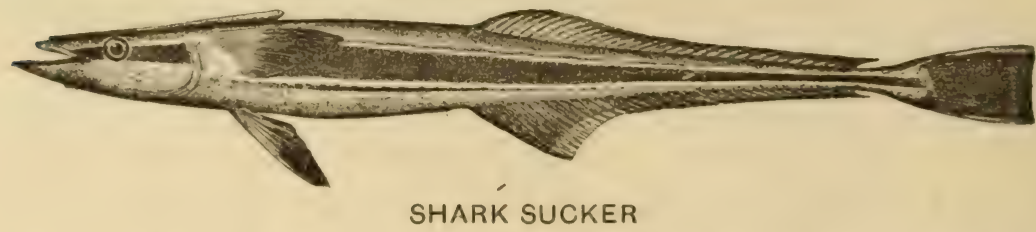

an elongate body which is often boldly striped black, white and gray, and the lower jaw produced in a flap. The Remora is a stouter fish 
uniformly colored and the lower jaw not produced. Its habitat is offshore and it is only of accidental oecurrence in our waters, whereas the Shark Sucker is not uncommon in late summer.

The Stargazer is a peculiar species quite unlike any other occurring on our coast. Its body is stout, its head large and squarish in form, the mouth vertical opening almost directly upward, and the small eyes placed far forward on the top of the head. Its habitat is southern and it is only of accidental occurrence near New York. The related Toadfish is a common species in our bays reaching a length of about fifteen inches. It is a soft finned mushy fish with a large blunt flattened head and protruding lower jaw like that of a bulldog. At the upper angle of the gill-cover are two diverging spines which are concealed in the skin, not as conspicuous as are the spines of marine sculpins. Its lower jaw is rimmed about with several fleshy flaps. The teeth of the Toadfish are rather short and blunt but they are firmly set and he knows well how to use them. One frequently finds a specimen isolated in some pool left by the falling tide, but it is dangerous to try and capture such an individual by the hand because of the chance of receiving a severe bite. One sometimes sees them lying on the bottom beside some pier; when in such a position if they be annoyed with a stick, they will sometimes fasten their jaws upon it so tenaciously that they may be lifted out of the water. Care should be taken not to confuse the Toadfish with the very different and much larger Angler, which commonly goes by the same name among fishermen.

There are two main divisions of the Blenny family, the first consisting of comparatively short-bodied species with a dorsal fin made up of weak spines in front and soft rays behind, the second consisting of more or less elongate eel-shaped or band-shaped fishes with a long dorsal fin consisting entirely or almost entirely of spines. The first group abound about tropical reefs or shores, whereas the second group are characteristic of cold northern seas. New York occupies just the intermediate territory where neither group is much in evidence. A small member of the southern Blennies which occurs here occasionally is the Striped Blenny. Its body is compressed, the depth contained about three and one half times in the length to the base of the tail fin. Almost the entire length of its back is occupied by a rather high fin consisting of about eleven weak spines and nineteen soft rays, both of about the same height and not even separated from one another by an indentation. The tail fin is short and rounded, the mouth moderately large with a single row of slender comb-like teeth in each jaw. The gill openings are small, 
restricted to the side above the pectoral fins and the body is scaleless. The narrow ventral fins are situated at the throat in front of the pectoral fins. The fish is mottled in color and well adapted for hiding, as it generally does, among sea weed. Its boldest color markings are on the anterior part of the dorsal which is broadly and strikingly striped. The Rock Eel, which is uncommon in this vicinity in the colder months of the

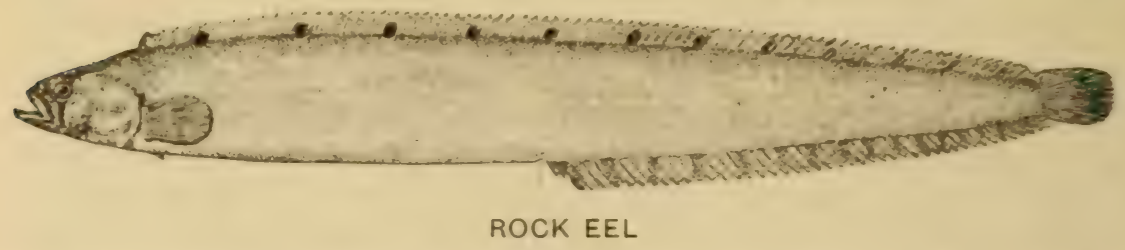

year, is our representative of the northern group of Blennies. It is a fish easy to recognize, having an elongate eel-like band-shaped body, a small head and a low dorsal fin made up of short sharp spines and their connecting membrane, which extends the entire length of the back. Its colors are also characteristic. At intervals there are round black blotches on the dorsal fin and a curved stripe extends downward from the nape through and beyond the eye. The Ghostfish is another elongate some-

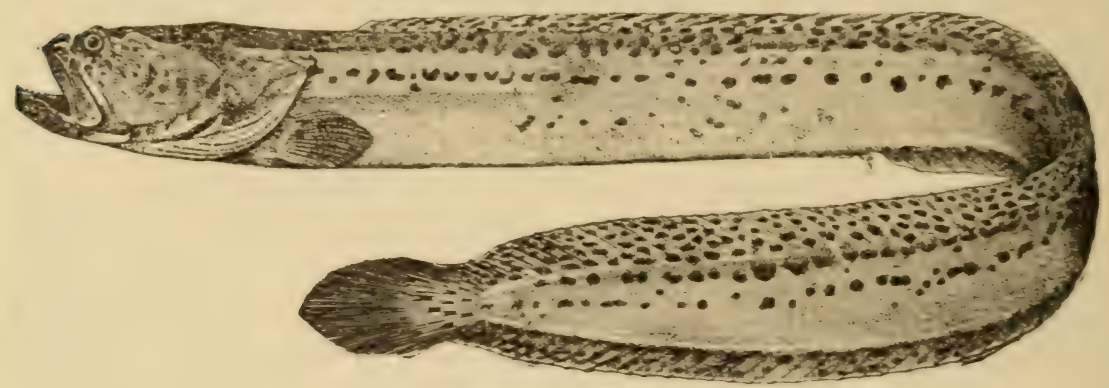

GHOSTFISH

what ecl-like species belonging to an allied family. It agrees with the Rock Eel in having the elongate dorsal fin made up entirely of spines, about seventy-three of these. It differs from that species in having a large squarish head with a large mouth opening obliquely upward and in its pale brownish color, irregularly spotted above and on the back fin. Its eyes are placed far forward and near the top of the head. The Wolf Fish also resembles somewhat the Rock Eel, but its back fin is much higher, the spines composing it more flexible, and it is shorter bodied, the 
greatest depth being eontained about five and one half times in the length to the base of the tail fin. The head is large and compressed and the mouth armed with large, characteristic, fang-like teeth which are visible even when it is closed. Ghost fish and Wolf Fish are both northern species of rare occurrence with us.

The Eelpout is a very peculiar creature common in this vicinity at

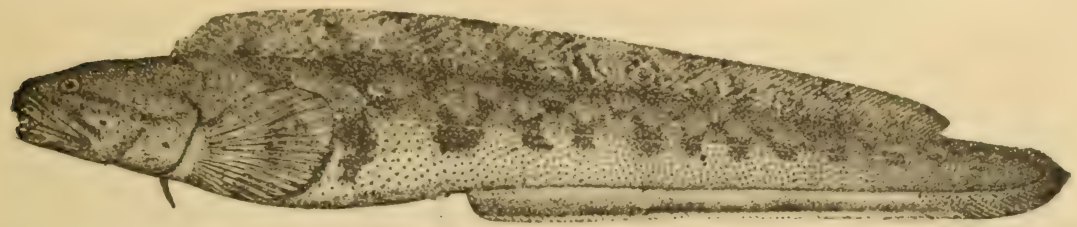

EELPOUT

moderate depths, as on the fishing banks visited by anglers in pursuit of the Sea Bass and other valuable species. It is somewhat elongate and eel-shaped and known to the fishermen hereabouts almost uniformly as "Conger Eel," although this name rightly belongs to a true eel which is very dissimilar. The Eelpout may be recognized at once by the peculiar formation of its fins. It has a rather high elongate back fin which stops before reaching the tail, and a narrow fringe-like fin extends around the end of the tail to be prolonged forward to the middle of the body as the anal fin. The pectoral fins are broad and rounded, and rudimentary ventral fins are situated before them at the throat. The Eelpout is a grotesque and repulsive looking creature, of a strong yellow color more or less mottled with darker. The peculiar Slippery Dick is another northern form occasionally taken here in fall. It has an elongate body with a low unbroken fin which starts on the back above the pectoral and extends around the tail and forward to the vent as the anal. There are no ventral fins, unless a forked barbel on either side below the corner of the mouth be considered as such.

\section{The Codfishes}

(Anacanthini)

The Codfishes abound in cold northern seas swimming at moderate depths. Many of them are prized for food and they have perhaps always formed the most important factor in the fisheries of English speaking people. Ordinarily they do not occur on our coast near shore south of Cape Cod, except in the winter time when several species regularly 
visit the vicinity of New York. They are moderately elongate, fine scaled fishes with no spiny fins. Typically they have the back fin broken up into three more or less isolated portions and the anal fin broken up into two.

The Silver Hake, which is sometimes common near our shores in spring and fall, has the largest mouth of any, with prominent pointed teeth and a long projecting lower jaw without any barbel at its tip. Its eye is rather large, its body tapers posteriorly to a slender weak caudal peduncle and the tail fin is small, squarish or slightly emarginate. The large mouth, absence of a barbel at the chin and silvery color will readily distinguish it from any other species having three back fins.

The three typical Cods are the Pollack, Codfish and the Haddock; all of these having three separate fins on the back and a barbel at the tip of the chin, which is smallest in the Pollack. The Pollack is the most active species with a tendency to swim nearer the surface than the others. Unlike the other two, its lower jaw is slightly longer than its upper, also its tail fin is more firmly built and more decidedly forked. Cod and Haddock have the lower jaw somewhat shorter than the upper, most noticeably so in the Haddock, and their tail fins are squarish or slightly emarginate. The lateral line of the Codfish is situated in a narrow white longitudinal stripe and that of the Haddock in a narrow black longitudinal stripe. The Codfish has small yellowish spots scattered on the back and sides whereas the Haddock is quite uniformly colored. Other marks which will aid in identifying this latter species are a pointed first dorsal fin and a large black blotch on the side under it and immediately below the lateral line. All three species reach a large size. As a general food fish, the Cod is superior to the other two, although with special cooking they are very fine and would probably be even more agreeable to certain palates than the Cod. The flesh of the Pollack being comparatively oilless, is improved by cooking with fat pork or some such material. That of the Haddock, which has a tendency to be too firm and dry, is unsurpassed as the basis for a chowder.

The Pollack commonly reaches a weight of ten pounds, rarely of twenty-five pounds, with a length of orer three feet. The largest Cod recorded from New England weighed $211 \frac{1}{2}$ pounds and was over six feet long. Ten or twelve pounds is, perhaps, the ordinary weight of full-grown fish, and twenty-five-pounders are common enough. Individuals taken offshore are apt to be larger than those from the coast. The usual size of the Haddock is about three or four pounds, and the maximum about 17 pounds. 
The Tomcod is a fish resembling the true Codfish very closely, but very much smaller in size. It abounds along our shores in spring and fall and occurs sparingly at all seasons, growing to be only about one foot in length and usually much smaller. It is fished for extensively and makes a very delicious pan fish. The tail fin of the Tomeod is somewhat rounded instead of squarish or emarginate as in its larger

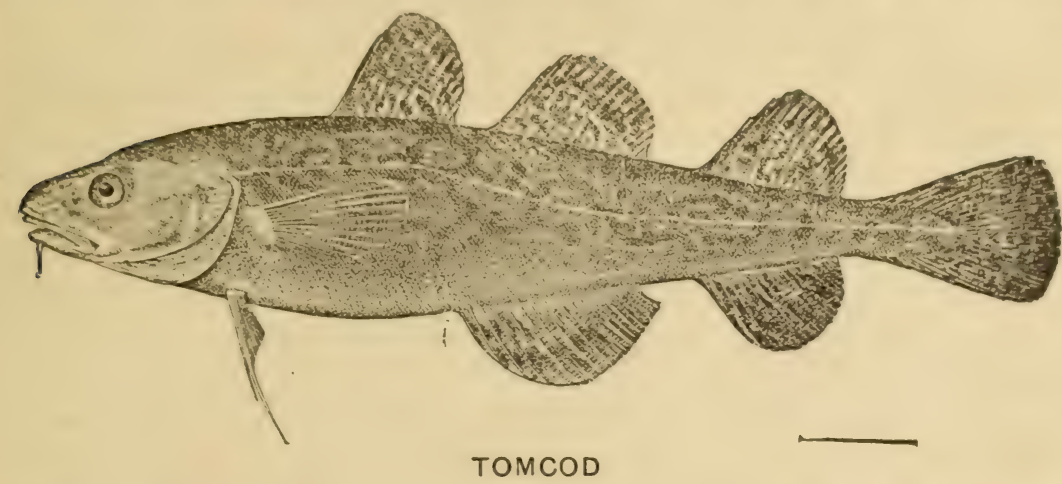

relative. Its vent is situated in front of the second dorsal fin instead of below that fin and its color is somewhat different, rather coarsely mottled. The Boston Hake, Spotted Hake and Squirrel Hake or Ling. are three members of the Cod Family in which the anal fin is single with an even margin throughout its length. There is a small pointed dorsal fin over the shoulders followed by a longer one which occupies the remainder

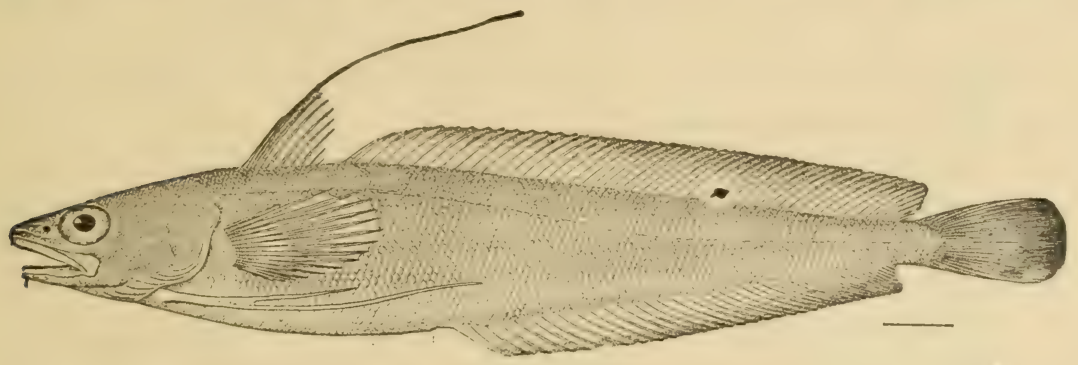

SQUIRREL HAKE

of the back and which resembles the anal. The ventral fins are situated under the head, each one consisting of a slender forked filament. In the Boston Hake and Squirrel Hake, the small anterior dcrsal fin ends in a slender filament, whereas in the Spotted Hake that fin is simply pointed. Small specimens of the Spotted Hake may be reccgnized 
by conspicuous white spots placed at intervals along the lateral line. The Boston Hake grows to be a large fish reaching a much larger size than the Squirrel Hake and has a somewhat more northern or deeper water range. Small specimens may be distinguished from the Squirrel Hake by the somewhat smaller scales, there being about one hundred and thirty-eight in the length of the body as opposed to one hundred and ten. The proportions of the slender fint in are also somewhat different in these two species. In the Boston Hake, its tip does not quite reach to the beginning of the anal fin, whereas in the Squirrel Hake, it reaches beyond that point. Hakes are large eyed, bottom fishes, more or less nocturnal in habit. Their lower jaws are shorter than their upper with a minute barbel at the chin; unlike most "over-shot" fishes, their mouths are large. Boston Hake and Ling are most plentiful in this vicinity in fall and winter, whereas the young of the Spotted Hake may be found in the bottoms of rather deep muddy bays at any season.

Ling, that is, the Hakes, and the Silver Hake, also called "Frost Fish," are probably caught in larger quantity by more rod and line anglers from the city than any other fishes. Together with the Cod and an occasional Haddock or other fish, they make up the bulk of catch in this vicinity during the colder months. Boatloads of fishermen are taken on daily trips to the offshore banks in their pursuit. Such deep-water fishermen use heavier tackle than those who fish primarily for Weakfish, and instead of having a restricted fishing season in the summer, fish throughout the year, in the warmer months turning their attention to Fluke, Sea Bass, etc. The size of the day's catch is a larger item in the enjoyment of a day's fishing for these species, evidence of the superiority of the Weakfish as a true game fish.

There is a single fresh-water species of the Cod family, the Freshwater Ling, widely distributed in far northern lakes, an ugly sluggish soft fleshed fish resembling the Hakes very much in appearance, but its ventral fins, although narrow and pointed, are more normal. It has an "over-shot" mouth with a conspicuous barbel on its chin, dorsal and anal fins long, the former preceded by a short separate fin, caudal fin rounded.

\section{The Flatfishes}

(Heterosomata)

The Flatfishes or Flounders and Soles are perhaps the easiest group to recognize at sight. They are flattened species, peculiarly 
modified in adaptation to lying on the bottom. The eyes are both situated on one side of the body and the reverse or down side is'colorless. Four of our species have the eyes and color on the right side of the body. The remaining six have them on the left side.

Among the former, the Halibut is the only one which has a large symmetrical mouth armed with conspicuous teeth and a concave tail fin. The Halibut is a large northern fish which has never been more than occasional in this vicinity in winter. Of late years, its numbers in the Atlantic have been reduced and as a result it occurs near New York still less frequently.

The Halibut is one of the very largest of fishes, ordinary full-grown examples weighing between 100 and 150 pounds. They rarely exceed 250 pounds, but there are several records from 300 to 400 pounds and one from the coast of Sweden weighed 720 pounds. A fish taken off the New England coast in 1917 must have been just about this same size. It weighed between 600 and 700 pounds when dressed and was nine feet in length.

The abundant Winter Flounder or "Flatfish" is a right-handed species with comparatively small and crooked mouth and a rounded tail fin. Though there is a record for a twenty-inch Winter Flounder weighing five pounds it is very rare to find them over fifteen inches long and a pound and a half in weight. Flounders run very early in the spring in the vicinity of New York, and are the first fish caught by rod and line anglers from the city. They are abundant in most of our shallow or muddy bays and accessible to many who have not a chance to angle for other species. The Rusty Dab which replaces it in deeper water offshore, resembles the Winter Flounder, but has the lateral line arched over the pectoral fin instead of being straight as in that species. In outline it is concave over the eyes, giving the effect of a protruding snout, and the under surface, instead of uniform white, is margined with dull yellow along the base of the dorsal and anal fins. The American Sole sometimes called "Hog-choker" has the mouth very small and crooked. Its eyes are also small and it lacks a pectoral fin on the colored side. Its scales are extremely rough and full-grown specimens usually have rounded or oval blackish spots on the white lower surface. The color of the upper parts is also characteristic, with several narrow dark cross streaks and a single central longitudinal one. This is our only representative of the famous European Sole. It is of small size and worthless for food. 


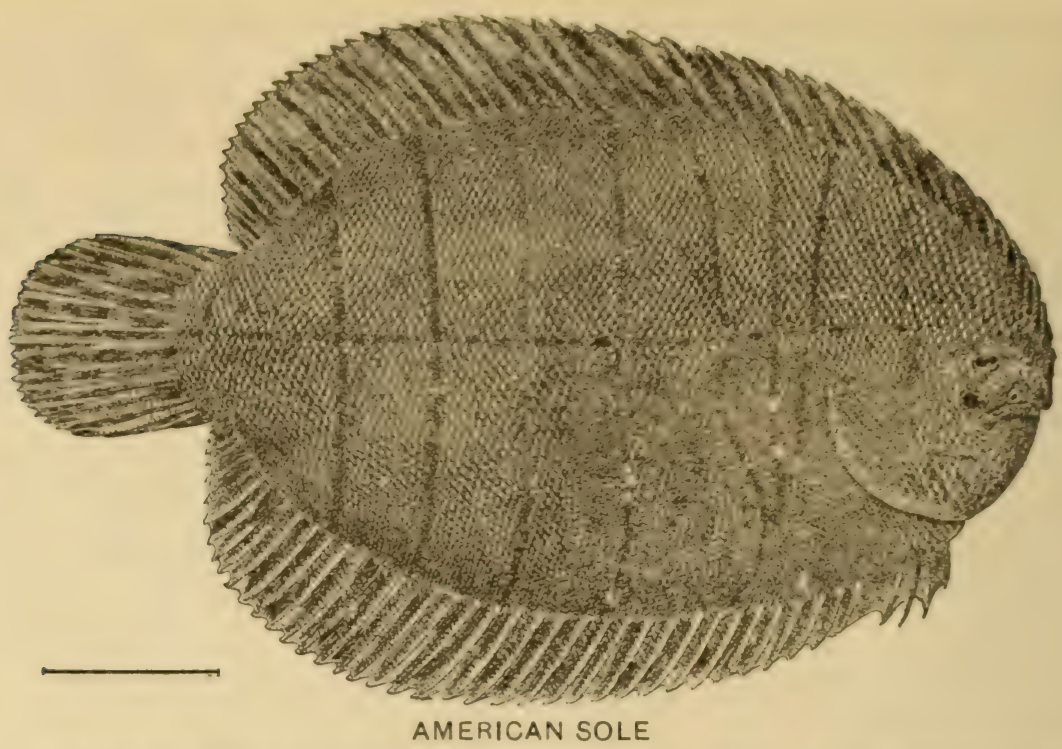

Of the six left-handed species, three have rather large symmetrical mouths with conspicuous teeth and the ventral fins also symmetrical and equal to one another in size. The only common form is the Summer Flounder or "Fluke," too well known to need description. When full-

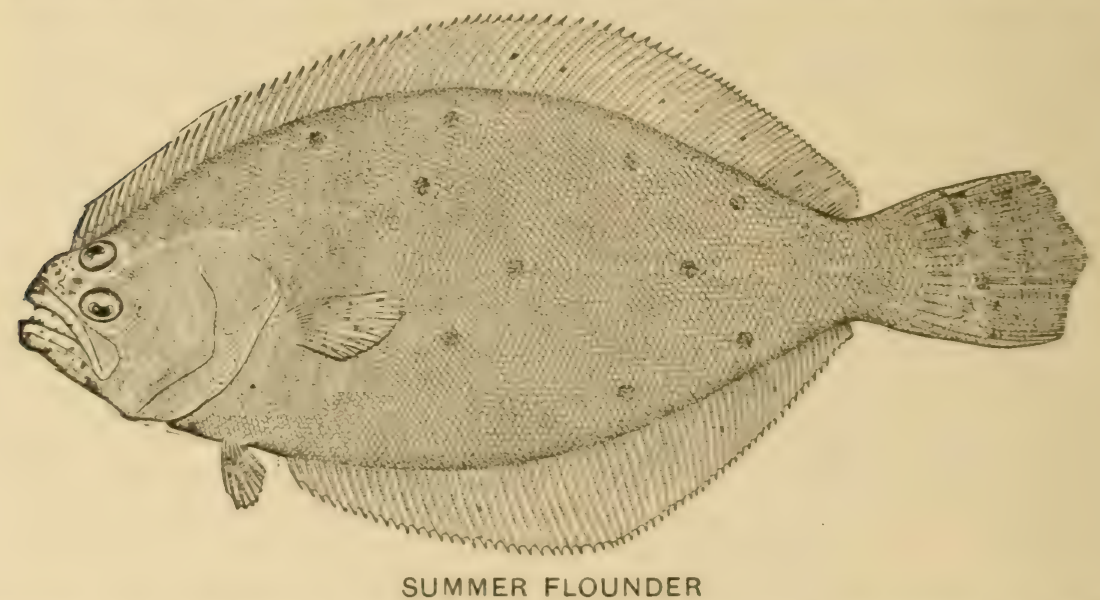

grown this fish usually weighs about five pounds. Ten-pound fish are not uncommon, and are about thirty inches long. There is a record of one twenty-six pounds in weight. The Southern Flounder, which resembles it. 
very closely and replaces it on the southern shores of the United States, has been recorded from this vicinity where it certainly is very rare. Its gill rakers are shorter, wider set and fewer than in our Summer Flounder, there being about ten on the lower limb of the first gill arch instead of fifteen or sixteen. Related to the Summer Flounder and representing it in deeper water off shore much as the Rusty Dab represents the Winter Flounder, is the Four-spotted Flounder, a smaller fish which may be readily recognized by four large, dark, ocellated spots on its colored side, one pair (above and below) in the neighborhood of the middle of the body and the second pair, closer together, further back near the tail.

The remaining three species are the Sundial, Sand Flounder and Small-mouthed Flounder. They differ from the three just considered in having the ventral fins unsymmetrical, the one on the eyed side extending along the ridge of the abdomen. The Sundial is a not uncommon species in this vicinity. Its body is exceptionally deep, the depth contained about one and three-fifths times in the length to the base of the tail fin, and its color is characieristic, the upper surface being covered with rather small sharp blackish spots of varying size. Its flesh is translucent, and when held to the light a shadow may be seen through the fish, in spite of which fact, the Sundial is one of the most delicious species. But on account of its comparative scarcity and small size, it will probably never be known as a table fish. The Sand Flounder is a small form common in the tropics and of accidental occurrence here. Its mouth is decidedly small, its eyes unusually large. In color it is rather irregularly waved and mottled, and has several ocellated spots, which are not very bold, one situated in the middle of the body somewhat posteriorly. The body practically ends at the termination of dorsal and anal fins which almost touch the beginning of the caudal fin above and below. This is quite unlike the Sundial which has a fairly well marked caudal peduncle. The Small-mouthed Flounder is a rather broad, that is, deep-bodied, small southern species with a very small head contained about four and four-fifths times in the length to the base of the tail fin. Unlike the Sundial and Sand Flounder, its lateral line has practically no arch above the pectoral fins. Its color is uniform. This species is said to occur here in fall though we have never seen it. 
XVII. The Frog Fishes, etc.

\section{(Pediculati)}

This is the final group of fishes dealt with and contains only three species. The Angler, sometimes called "Toadfish," is common in deep water off shore and occurs coastwise during the colder months. This fish has a tremendous mouth with many pointed, dangerous looking teeth in its jaws, the lower jaw being the longer. Its head is very large and broad and on top of the head are two or three erectile spiny rays with small membranous tags at their tips, which are said to be used to lure small fishes within reach of the great mouth. Anglers are tadpoleshaped and sluggish but extremely voracious. Small diving birds have been taken from their stomachs whole.

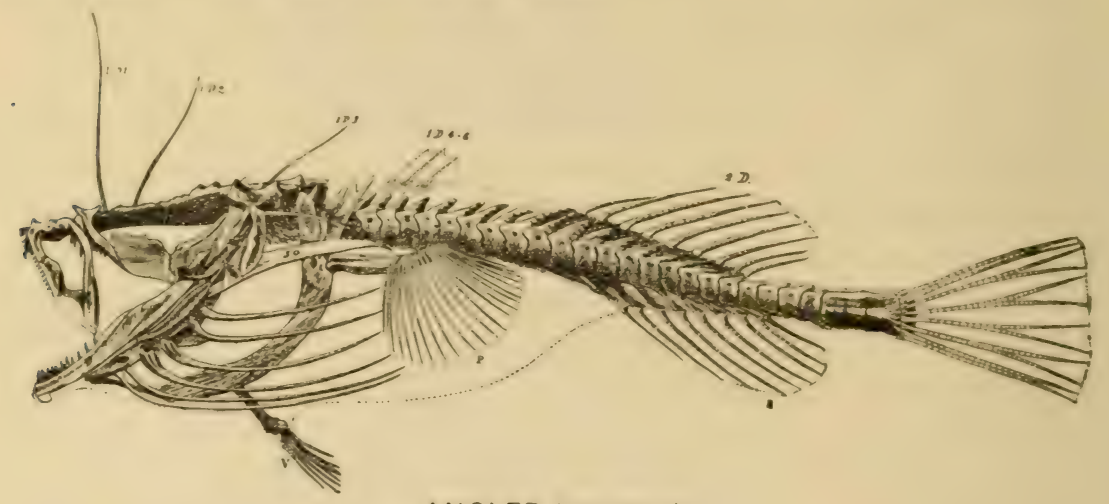

ANGLER (skeleton)

The Mousefish is a small species of peculiar form. Not only are its pectoral fins excerted from the body so as to give the impression of legs, but it is covered with many irregular flap appendages, which, added to its mottled black, white and yellow color, render it almost invisible among the drifting sargassum or gulf weed which is practically the only place in which it is found. As New York is situated back from the Gulf Stream in a long reentrance in the coast line, the Mousefish is a very rare straggler here although it has been recorded.

The Batfish is a very peculiar flattened bottom species with a hard outer surface covered with small rough nodules. Except for the elongate tail portion which extends backward, it is roughly triangular in form, the apex of the triangle being at the snout, which is prolonged in a pointed process well beyond the body contour. At the outer angles of the triangle are two stout protrusions from the body contour on which the 


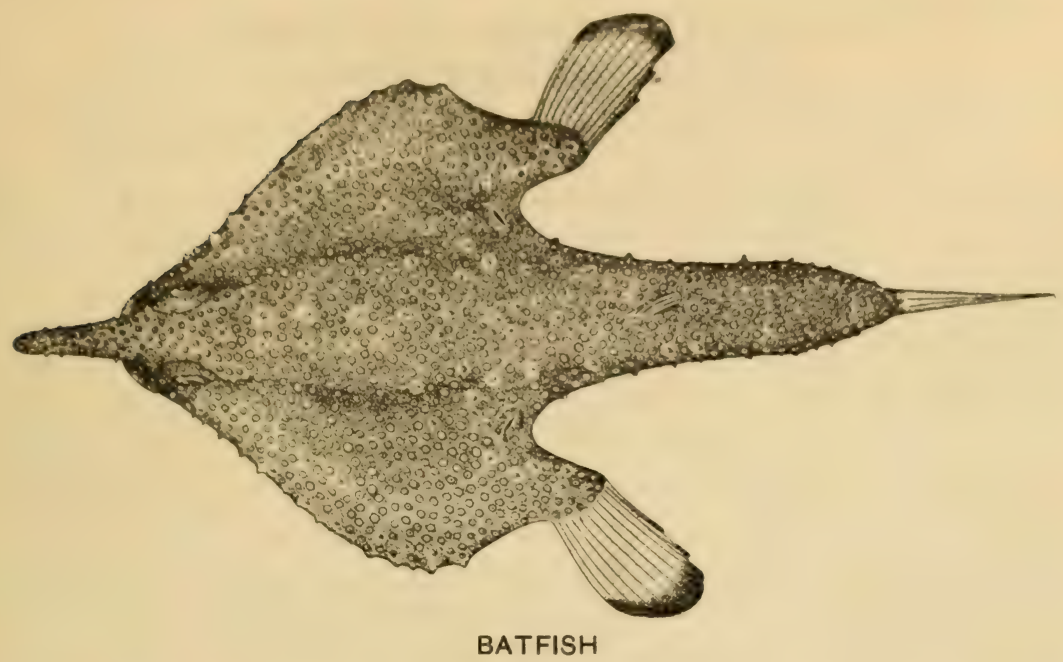

pectoral fins are situated. The narrow ventral fins are situated in the center of the lower surface of the body, and the transverse mouth is also on the lower surface of the body beneath the base of the long snout. This weird creature has a southern range and is of accidental occurrence here in summer, its occasional capture generally giving rise to newspaper articles on an unknown fish provided with legs instead of fins.

Thus ends the "Review of Local Fishes." Those interested in pursuing the subject of ichthyology farther will find Doctor Jordan's "Guide to the Study of Fishes" full of interest and information. Doctor Goode's "American Fishes" tells much of the habits, history and modes of capture of many species, while "American Food and Game Fishes," by Jordan and Evermann, is a more recent work on the same general lines, but somewhat more technical and treating of many more species. 


\section{A List of the Fishes Known to Have Occurred Within Fifty Miles of New York City.}

"What! will the line stretch out to the crack of doom?"-Macbeth.

The following list includes two hundred and forty-seven species of fishes which are definitely known to have occurred within fifty miles of New York City, exclusive of those which may occur under more than twenty-five fathoms of water. The region has not been exhaustively studied and probably from time to time others will be added. Inder each species is given a brief statement of its abundance and the dates between which our records show it to be present. Many species of fishes have migrations almost as extensive and as well marked as to dates of occurrence as are those of birds, but the migrations of fishes are comparatively little known, and that which we are able to say of them will be subject to a correspondingly great amount of revision. It is hoped that fishermen, or others who may chance to make observations of local fishes which do not agree with this published list, will forward a statement of their findings to the Department of Fishes of the American Museum of Natural History. It is only by cooperation of this sort that we shall finally gain an adequate knowledge of our fishes.

\section{Family PETROMYZONIDE}

(Ascending fresh-water streams) ${ }^{1}$

1. Petromyzon marinus Linn. Sea Lamprey. Not uncommon. March to December 10.

2. Lampetra wilderi Gage. Brook Lamprey. Common locally. Spring. (Dean \& Sumner, Trans. N. Y. Ac. Sci., XVI, 1897. 321.)

\section{Fámily GALEID $\mathrm{E}$}

3. Mustelus canis (Mitch.) Smooth Dogfish. Common. June to December 13.

4. Galeocerdo tigrinus Mül. \& Hen. Tiger Shark. Casual in late summer (September 11).

5. Prionace glauca (Linn.) Blue Shark. One record. A large specimen taken near City Island, N. Y., in late October, 1911, was presented to the American Museum of Natural History by Mr. Alfred Frank, of New York.

${ }^{1} \mathrm{As}$ an aid to those consulting this list, the habitat of the species near New York, whether freshwater or marine, is given. This status does not hold absolutely, certain marine species occasionally running into fresh-water, and vice versa. 
6. Carcharhinus obscurus (Le Sueur). Dusky shark. Has been recorded. Its status is uncertain.

7. Carcharhinus milberti (Mul. \& Hen.) Brown Shark. Common. Mid-June to mid-September. Almost all adults females.

8. Carcharhinus commersonii. Blainv. Cub Shark. Males uncommon in late summer (August).

9. ('archarhinus limbatus (Mül. \& Hen.) Edged Shark. One record. Mr. Edwin Thorne of Babylon, L. I., has the jaws of a large specimen which he took in Great South Bay in midsummer several years ago. July 14, 1910 .

\section{Family SPHYRNID压}

(Marine)

10. Sphyrna zygæna (Linn). Hammerhead Shark. Uncommon. July to September.

\section{Family ALOPIID无 \\ (Marine)}

11. Alopias vulpinus (Bonnaterre). Thresher Shark. Occasional. April to July 24 (1918, Islip, J. T. N.)

\section{Family CARCHARIID艮}

(Marine)

12. Carcharias littoralis (Mitch.) Sand Shark. Common. June to October.

\section{Family LAMNIDÆ}

(Marine)

13. Isurus tigris (Atwood). Mackerel Shark. Accidental. October.

14. Carcharodon carcharias (Linn.) White Shark. "Man-eater." Accidental in summer. June to July 14, 1916.

\section{Family CETORHINID压}

(Marine)

15. Cetorhinus maximus (Gunner). Basking Shark. Accidental.

Family SQUALIDE

(Marine)

16. Squalus acanthias Linn. Spined Dogfish. Not uncommon. October to April. Rarely occurs in summer. 


\section{Family SQUATINIDE}

(Marine)

17. S'quatina squatina (Linn.) Monkfish. Uncommon. Summer.

\section{Family RAJIDE}

(Marine)

18. Raja erinacea Mitch. Common Skate. Common Resident.

19. Raja diaphanes Mitch. Big Skate. Tolerably common. September to December 30, probably resident.

20. Raja eglanteria Bosc. Clear-nosed Skate. Not uncommon. July to September.

21. Raja stabuliforis Garman. Barn-door Skate. Common. October to June.

\section{Family NARCOBATIDÆ (Marine)}

- 22. Tetronarce occidentalis (Storer). Torpedo. Accidental. Summer.

\section{Family DASYATIDE}

(Marine)

23. Dasyatis centrura (Mitch.) Common Sting Ray. Uncommon, formerly common. July and later in the year.

24. Pteroplatea maclura (Le Sueur). Butterfly Ray. Uncommon.

\section{Family MYLIOBATIDE}

(Marine)

25. Rhinoptera bonasus (Mitch.) Cow-nosed Ray. Uncommon. Summer and autumn.

\section{Family ACIPENSERIDÆ}

(Ascending fresh water streams from the sea.)

26. Acipenser sturio Linn. Common Sturgeon. Not uncommon. February to fall.

27. Acipenser brevirostrum Le Sueur. Short-nosed Sturgeon. Rare. May.

\section{Family LEPISOSTEID A}

(Fresh-water)

28. Lepisosteus osseus Linn. Long-nosed Gar. Occasional.

\section{Family SILURIDA}

29. Felichthys marinus (Mitch.) Gaff-topsail Catfish. Sometimes common. August. (Marine).

30. Galeichthys felis (Linn.) Sea Catfish. Rare. (Marine). 
31. Ictalurus punctatus (Raf.) Spotted Catfish. Locally common. Resident. Introduced. (Fresh-water).

32. Ameiurus lacustris (Walb.) Mississippi Catfish. Locally introduced. (Fresh-water).

33. Ameiurus catus (Limn.) White Catfish. Tolerably common. Resident. (Fresh-water).

34. Ameiurus nebulosus (Le Sueur). Horned Pout. Tolerably common. Resident. (Fresh-water).

35. Schilbeodes gyrinus (Mitch.) Stone Catfish. Not uncommon. Resident. (Fresh water).

36. Schilbeodes insignis (Richardson). Mud Catfish. Recorded. (Fresh-water).

\section{Family CATOSTOMIDÆ}

(Fresh-water)

37. Catostomus commersonii (Lac.) White Sucker. Common resident.

38. Erimyzon sucetta oblongus (Mitch.) Chub Sucker. Tolerably common. Resident.

39. Moxostoma macrolepidotum (Le Sueur). Red Horse. Recorded.

\section{Family CYPRINIDE}

(Fresh-water)

40. Carassius auratus (Linn.) Goldfish. Common. Resident. Introduced.

41. Cyprinus carpio Linn. Carp. Common. Resident. Introduced.

42. Idus idus Linn. Golden Ide. Introduced. Resident.

43. Tinca tinca Linn. Tench. Introduced. Resident.

44. Hybognathus nuchalis regius (Girard). Silvery Minnow. Tolerably common. Resident.

45. Pimephales notatus (Raf.) Blunt-nosed Minnow. Recorded.

46. Semotilus corporalis (Mitch.) Fallfish. Not common. Resident.

47. Semotilus atromaculatus (Mitch.) Horned Dace. Common. Resident.

48. Leuciscus vandoisulus Val. Rosy Dace. Recorded.

49. Leuciscus margarita Cope. Gold-thread Shiner. Recorded.

50. Scardineus erythrophthalmus (Linn.) Pearl Roach. Abundant. Resident. Introduced.

51. Abramis crysoleucas (Mitch.) Golden Shiner. Common. Resident. 
52. Notropis bifrenatus (Cope). Bridled Minnow. Locally common. Resident.

53. Notropis procne (Cope). Delaware Minnow. Common. Resident.

54. Notropis hudsonius amarus (Girard). Spawn-eater. Rare. Resident.

55. Notropis analostanus (Girard). Silverfin. Locally common Resident.

56. Notropis cornutus (Mitch.) Redfin. Common. Resident.

57. Notropis chalybarus (Cope). Abbott's Minnow. Recorded.

58. Notropis amcenus (Abbott). Raritan Minnow. Recorded.

59. Rhinichthys cataractee (Val.) Long-nosed Dace. Rare. Local. Resident.

60. Rhinichthys atronasus (Mitch.) Black-nosed Dace. Common. Resident.

61. Hybopsis kentuckiensis (Raf.) Hornyhead. Occasional.

62. Exoglossum maxillingua (Le Sueur). Cut-lip Minnow. Rare. (Eugene Smith.)

\section{Family ELOPID $Æ$ \\ (Marine)}

63. Tarpon atlanticus (C. \& V.) Tarpon. Accidental. Summer and fall (October).

64. Elops saurus Linn. Big-eyed Herring. Casual. October.

\section{Family ALBULIDE}

\section{(Marine)}

65. Albula vulpes (Linn.) Ladyfish. Accidental. October. Bean, Fishes of New York, Bull. N. Y. State Mus., 1903.

\section{Family DOROSOMIDE}

(Fresh-water)

66. Dorosoma cepedianum (Le Sueur). Gizzard Shad. Uncommon. Resident.

\section{Family CLUPEID蚱}

67. Etrumeus sadina (Mitch.) Round Herring. Uncommon. July to October. (Marine).

68. Clupea harengus Linn. Herring. Irregular. All seasons. (Marine).

69. Pomolobus mediocris (Mitch.) Hickory Shad. Common. August through November. (Ascending fresh-water streams from the sea.) 
70. Pomolobus psendoharengus (Wilson). Alewife. Abundant. February to December 18. (Ascending fresh-water streams from the sea).

71. Pomolobus restivalis (Mitch.) (ilut Herring. Not uncommon. August. (Ascending fresh-water streams from the sea).

72. Alosa sapidissima (Wilson). Shad. Common. (March) May to October (December). (Ascending fresh-water streams from the sea).

73. Opisthonema oglinum (Le Sueur). Thread Herring. Sometimes abundant. July and August. (Marine).

74. Brevoortia tyrannus (Latrobe). Menhaden. "Mossbunker." Abundant. May to November (December 5). (Marine).

Family ENGRAULIDIDÆ

(Marine)

75. Anchoviella perfasciata (Poey). Flat Anchovy. Recorded. September.

76. Anchoviella brownii (Gmelin). Striped Anchovy. Uncommon. Summer.

77. Anchoviella argyrophana (C. \& V.) Silvery Anchovy. Casual. June to August 20, when a specimen was taken at Long Beach, L. I., by T. D. Keim and C. Van Loan. Also November 18, Coney Island, W. H: Wiegmann.

78. Anchoviella mitchilli (C. \& V.) Common Anchovy. Common. May to October 30.

\section{Family SALMONID压}

79. Salmo salar Linn. Atlantic Salmon. Occasional. (Ascending fresh-water streams from the sea).

Salmo salar sebago (Girard). Landlocked Salmon. Introduced. (Fresh-water).

80. Salmo fario Linn. Brown Trout. Introduced. Resident. (Freshwater).

81. Salmo irideus Gibbons. Rainbow Trout. Introduced. (Mostly fresh-water).

82. Salvelinus fontinalis (Mitch.) Brook Trout. Formerly common. Now occurs in reduced numbers. (Mostly fresh-water).

83. Salvelinus alpinus (Linn.) Golden Trout. Introduced. Rare. (Eugene Smith). The various Golden Trouts of northeast America are races of the European Saibling (Salvelinus alpinus) or closely related to that fish. (Fresh-water). 


\section{Family ARGENTINIDÆ}

(Ascending fresh-water streams from the sea)

84. Osmerus mordax (Mitch.) Smelt. Common. Resident.

\section{Family SYNODONTIDA}

\section{(Marine)}

85. Synodus firtens (Linn.) Lizard Fish. Sometimes common. October to October 30 .

\section{Family ANGUILLIDE}

86. Anguilla rostrata Le Sueur. Common Eel. Abundant. Resident. (Fresh and salt water).

\section{Family LEPTOCEPHALIDÆ}

87. Leptocephalus conger (Linn.) Conger Eel. "Sea Eel." Uncommon. Summer to December 30. (Marine).

\section{Family UMBRID $Æ$ \\ (Fresh-water)}

88. Umbra pygmøa (De Kay). Mud Minnow. Common. Resident. Family ESOCID $Æ$

$$
\text { (Fresh water) }
$$

89. Esox americanus (Gmelin). Banded Pickerel "Pike." Tolerably common. Resident.

90. Esox reticulatus (Le Sueur). Chained Pickerel. Tolerably common. Resident.

\section{Family PECILIIDÆ}

(Mostly salt-water)

91. Fundulus majalis (Walb.) Bass Killy. Abundant. Resident.

92. Fundulus heteroclitus macrolepidotus (Walb.) Mummichog. Common Killy. Abundant. Resident.

93. Fundulus diaphanus (Le Sueur). Fresh-water Killy. Ccmmon. Resident. (Fresh-water).

94. Fundulus luciae (Baird). Lucy's Killy. Occasional. July. (Fowler, Science, October 15, 1909).

95. Lucania parva (Baird \& Girard). Rain-water Fish. Common. (Fresh and brackish water).

96. ('yprinodon rariegatus Lac. Sheepshead Minnow. Abundant. Resident. 


\section{Family BELONIDÆ}

(Marine)

97. Tylosurus marinus (Walb.) Billfish. Common. June to Dereember.

\section{Family HEMIRAMPHID $\mathbb{E}$}

(Marine)

98. Hyporhamphus roberti (C.\& V.) Halfbeak. Uncommon. August to October 16.

\section{Family EXOCOETIDÆ}

(Marine)

99. Exonautes speculiger (C. \& V.) Flying Fish. Accidental.

100. Cypselurus heterurus (Raf.) Bearded Flying Fish. Recorded.

101. Cypselurus furcatus (Mitch.) Double-Bearded Flying Fish. Recorded.

\section{Family GASTEROSTEIDA}

(Brackish water)

102. Pygosteus pungitius (Linn.) Ten-spined Stickleback. Common. Resident.

103. Gasterosteus bispinosus Walb. Two-spined Stickleback. Common. Resident.

104. Apeltes quadracus (Mitch.) Four-spined Stickleback. Abundant. Resident.

\section{Family FISTULARIIDA}

(Marine)

105. Fistularia tabacaria (Linn.) Trumpet Fish. Uncommon. September and October, to October 16.

\section{Family SYNGNATHIDÆ}

(Marine)

106. Syngnathus fuscus Storer. Pipefish. Abundant. June to December 13.

107. Hippocampus hudsonius De Kay. Sea Horse. Sometimes common. April to November. Casual in winter. 


\section{Family APHREDODERID蚱}

(Fresh-water)

108. A phredoderus sayanus (Gilliams). Pirate Perch. Tolerably common. Resident.

\section{Family ATHERINIDE}

109. Kirtlandia laciniata (Swain). Rough Silverside. Occasional. (Marine).

110. Menidia gracilis (Günth.) Fresh-water Silverside. Common. Resident. (Fresh-water).

111. Menidia menidia notata (Mitch.) Common Silverside. Abundant. Resident. (Marine).

\section{Family MUGILIDÆ}

(Marine)

112. Mugil cephalus Linn. Striped Mullet. Resident. Abundant in late summer and fall. Hibernates.

113. Mugil curema C. \& V. White Mullet. Common. August to November 9 .

\section{Family SPHYRANIDE}

(Marine)

114. Sphyrcena borealis De Kay. Northern Barracuda. Rare. June to November 16.

Family POLYNEMIDE

(Marine)

115. Polydactylus octonemus (Girard). Threadfin. Accidental. September.

\section{Family AMMODYTIDE}

(Marine)

116. Ammodytes americanus De Kay. Sand Eel. Abundant. Resident.

\section{Family MULLIDA}

(Marine)

117. Mullus auratus Jordan \& Gilbert. Goatfish. Occasionally common. September and October. 


\section{Family MICROPTERIDE}

(Fresh-water)

118. Pomoxis annularis Raf. Crappie. Introduced.

119. Pomoxis sparoides (Lac.) Calico Bass. Introduced.

120. Acantharchus pomotis (Baird). Mud Sunfish. Uncommon. Resident.

121. Ambloplites rupestris (Raf.) Rock Bass. Introduced. Resident.

122. Enneacanthus obesus (Baird). Spotted-fin Sunfish. Uncommon.

Resident.

123. Enneacanthus gloriosus (Holbrook). Holbrook's Sunfish. Resident.

124. Mesogonistius chrotodon (Baird). Black-banded Sunfish. Uncommon. Resident.

125. Lepomis auritus (Linn.) Long-eared Sunfish. Common. Resident.

126. Lepomis pallidus (Mitch.) Bluegill. Recorded.

127. Eupomotis gibbosus (Linn.) Sunfish. Abundant. Resident,

128. Micropterus dolomieu Lac. Small-mouthed Black Bass. Uncommon. Resident.

129. Micropterus salmoides (Lac.) Large-mouthed Black Bass.

Tolerably common. Resident.

\section{Family PERCIDÆ}

(Fresh-water)

130. Stizostedion vitreum (Mitch.) Pike Perch. Introduced. Resident.

131. Perca flavescens (Mitch.) Yellow Perch. Common. Resident.

132. Boleosoma nigrum olmstedi (Storer). Johnny Darter. Common.

Resident.

133. Boleichthys fusiformis (Girard). Fusiform Darter. Recorded. Family SERRANIDÆ

134. Roccus chrysops Raf. White Bass. Introduced. Resident. (Fresh-water).

135. Roccus lineatus (Bloch). Striped Bass. Common. Resident. (Fresh and salt water).

136. Morone americana (Gmelin). White Perch. Common. Resident. (Fresh and salt water).

137. Polyprion americanus (Bl. \& Sch.) Wreckfish. Accidental. August. (Osburn, Bull. N. Y. Zool. Soc., Nov., 1910). (Marine).

138. Centropristes striatus (Linn.) Sea Bass. Common. April to December. (Marine). 


\section{Family LOBOTIDA}

(Marine)

139. Lobotes surinamensis (Bloch). Triple-tail. Casual september and October.

\section{Family PRIACANTHIDA}

\section{(Marine)}

140. Pseudopriacanthus altus (Gill). Deep Big-eye. Casual. August 20 to October 30.

\section{Family LUTIANID曆}

(Marine)

141. Neomœnis aya (Bloch). Red Snapper. Accidental. October.

\section{Family HÆMULIDA}

(Marine)

142. Orthopristis chrysopterus (Linn.) Pigfish. Occasionally common. August to November 17.

\section{Family SPARIDE}

(Marine)

143. Stenesthes chrysops (Linn.) Porgy. Abundant. April to November.

144. Lagodon rhomboides (Linn.) Sailor's Choice. Occasional. Summer and autumn (October.)

145. Archosargus probatocephalus (Walb.) Sheepshead. Rare. June to October.

\section{Family EUCINOSTOMIDÆ}

(Marine)

146. Eucinostomus gula (C. \& V.) Mojarra. Accidental. August.

\section{Family KYPHOSID E}

(Marine)

147. Kyphosus sectatrix (Linn.) Bermuda Chub. Rare. September and October.

\section{Family SCIANIDE}

(Marine)

148. Cynoscion regalis (Bl. \& Sch.) Weakfish. Common. May 4 (1908) to November (December). 
149. Larimus fasciatus Holbrook. Banded Croaker. Aceidental. July and August.

150. Bairdiella chrysura (Latc.) Silver Perch. Sometimes common. July to December 18.

151. Scianops ocellatus (Linn.) Channel Bass. Rare. May to October.

152. Leiostomus xanthurus Lac. Spot. Lafayette Common. June to December 29.

153. Micropogon undulatus (Linn.) Croaker. Rare. July to September. Occasionally common.

154. Menticirrhus saxatilis (Bl. \& Sch.) Kingfish. Not uncommon. May 15 to November 4.

155. Pogonias cromis (Linn.) Drum. Tolerably common. May to December 18.

\section{Family POMATOMIDE}

\section{(Marine)}

156. Pomatomus saltatrix (Linn.) Bluefish. Young, "Snapper." Abundant. May to October.

\section{Family RACHYCENTRIDE}

(Marine)

157. Rachycentron canadum (Linn.) Crab-eater. Occasional. June. August 27 (Osburn, Bull. N. Y. Zool. Soc., Nov., 1911).

\section{Family CORYPHÆNIDA}

(Marine)

158. Coryphcena hippurus Linn. Common Dolphin. Accidental. August and September.

\section{Family STROMATEIDE}

\section{(Marine)}

159. Palinurichthys perciformis (Mitch.) Rudder Fish. Uncommon. August to October.

160. Peprilus paru (Linn.) Harvest Fish. Sometimes common. Summer.

161. Poronotus triacanthus (Peck.) Butterfish. Abundant. May, September and October. 


\section{Family CARANGIDE}

(Marine)

162. Oligoplites saurus (Bl. \& Sch.) Leatherjacket. Occasional. Summer (October).

163. Seriola zonata (Mitch.) Banded Rudder Fish. Tolerably common. August to October.

164. Seriola lalandi C. \& V. Amber Fish. Accidental. July and August.

165. Elagatis bipinnulatus (Q. \& G.) Runner. Accidental. August.

166. Decapturus punctatus (Ag.) Scad. Sometimes common. July

167. Trachurus trachurus (Linn.) Gascon. Accidental. October.

168. Trachurops crumenophthalmus (Bloch). Goggle-eyed Scad.

Not uncommon in summer. September to September 24.

169. Caranx hippos (Linn.) Jackfish. Tolerably common. July to October.

170. Caranx crysos (Mitch.) Hardtail. Tolerably common. July to October.

171. Alectis ciliaris (Bloch). Threadfish. Occasional in August.

172. Vomer setapinnis (Mitch.) Moonfish. Uncommon. June to October 30.

173. Selene vomer (Linn.) Lookdown. Uncommon. August to October.

174. Chloroscombrus chrysurus (Linn.) Bumper. Accidental. Summer.

175. Trachinotus falcatus (Linn.) Round Pompano. Tolerably common. August to October.

176. Trachinotus carolinus (Linn.) Common Pompano. Tolerably common. August to October 30.

\section{Family SCOMBRIDE (Marine)}

177. Scomber scombrus Linn. Mackerel. Sometimes common. May to July. Young taken in fall.

178. Scomber colias Gmelin. Chub Mackerel. Sometimes common. Early June to September 27.

179. Gymnosarda pelamis (Linn.) Oceanic Bonito. September.

180. Gymnosarda alleterata (Raf.) Little Tunny. September. (Bull. N. Y. Zool. Soc., November, 1911.)

181. Thunnus thynnus (Linn.) Tunny. Sometimes common. Summer. (Townsend, Forest \& Stream, October 22, 1910.) 
182. Germo alalunga (Gmelin). Albacore. Sometimes tolerably common. Summer. (W. I. De Nyse.)

183. Sarda sarda (Bloch.) Bonito. Common. June to October.

184. Scomberomorus maculatus (Mitch.) Spanish Mackerel. Common. May 31 (1918, H. C. Graff) to September.

\section{Family TRICHIURIDE}

(Marine)

185. Trichiurus lepturus Linn. Cutlass fish. Scabbard Fish. Rare. July and August.

\section{Family ISTIO PHORIDE}

(Marine)

186. Istiophorus nigricans (Lac.) Sailfish. Accidental. August. (Osburn, Bull. N. Y. Zool. Soc., Nov., 1910).

\section{Family XIPHIIDE}

(Marine)

187. Xiphias gladius Linn. Swordfish. June. (Bean, Fishes of New York, Bull. N. Y. State Mus., 1903.)

\section{Family LABRIDÆ}

(Marine)

188. Tautogolabrus adspersus (Walb.) Bergall. Common. Resident. 189. Tautoga onitis (Linn.) Blackfish. Tautog. Common. Resident.

Hibernates.

\section{Family EPHIPPID压}

(Marine)

190. Chcetodipterus faber (Broussonet). Spadefish. Occasional. Summer to September 20.

\section{Family CHÆTODONTIDA}

\section{(Marine)}

191. Chcetodon ocellatus Bloch. Butterfly Fish. Casual. October to October 30.

192. Pomacanthus arcuatus (Linn.) Black Angel Fish. Accidental.

$$
\text { Family TEUTHIDIDE }
$$

(Marine)

193. Teuthis hepatus Linn. Doctorfish. Accidental. October. 


\section{Family BALISTID E}

(Marine)

194. Balistes carolinensis Gmelin. Triggerfish. Occasional. July to September.

\section{Family MONACANTHID \&}

\section{(Marine)}

195. Monacanthus hispidus (Linn.) Filefish. Tolerably common August to November.

196. Alutera schopfii (Walb.) Orange Filefish. Tolerably common. May to November.

197. Alutera scripta (Osbeck). Unicorn Fish. Rare or accidental. (Eugene Smith.)

\section{Family OSTRACIIDA}

(Marine)

198. Lactophrys trigonus (Linn.) Trunkfish. Occasional. A ugust and October.

\section{Family TETRAODONTID正}

(Marine)

199. Lagocephalus loevigatus (Linn.) Smooth Swellfish. Rare. September to October.

200. Spheroides maculatus (Bl. \& Sch.) Swellfish. "Blowfish." Common. May to November.

\section{Family DIODONTID瓜}

(Marine)

201. Chilomycterus schœpfii (Walb.) Spiny Boxfish. Uncommon. September to November 5.

\section{Family MOLIDA \\ (Marine)}

202. Mola mola (Linn.) Headfish. Accidental. (Bean, Fishes of $\mathrm{N}$. Y., Bull., N. Y. State Mus., 1903.) June 2. 1918, off Coney Island.

\section{Family SCORPANID}

\section{-. (Marine)}

203. Sebastes marinus (Linn.) Rosefish. Accidental. August. (There is doubt if this species has occurred here naturally above twentyfive fathoms depth.) 
Family COTTIDE

(Mostly marine)

204. Cottus gracilis Heckel. Blob. Locally common. Resident. (Fresh-water).

205. Myoxocephalus ancus (Mitch.) Brassy Sculpin. Uncommon Resident.

206. Myoxocephalus mitchilli (C.\& V.) Mitchill's Sculpin. Rare.

207. Myoxocephalus gronlandicus (C. \& V.) Daddy Sculpin. Accidental.

208. Myoxocephalus octodecimspinosus (Mitch.) Hacklehead. Common. September to May. Occasional in summer.

209. Hemitripterus americanus (Gmelin). Sea Raven. Tolerably common. April and May, August (G. E. Hix), September to December.

\section{Family AGONIDE}

(Marine)

210. Aspidophoroides monopterygius (Bloch). Sea Poacher. Accidental. Summer. (There is doubt if this species has occurred here naturally above twenty-five fathoms depth.)

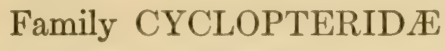

(Marine)

211. Cyclopterus lumpus Linn. Lumpfish. Uncommon. April and May.

\section{Family TRIGLID平}

(Marine)

212. Prionotus carolinus (Linn.) Carolina Sea Robin. Common May to November 21.

213. Prionotus evolans strigatus (C. \& V.) Striped Sea Robin. Common. May to November 4.

\section{Family CEPHALACANTHIDE}

(Marine)

214. Cephalacanthus volitans (Linn.) Flying Gurnard. Occasional August to October.

\section{Family GOBIID $\approx$}

(Marine)

215. Gobiosoma bosci (Lac.) Naked Goby. Tolerahly common Autumn. 


\section{Family ECHENEIDIDA}

\section{(Marine)}

216. Echeneis naucrates Linn. Shark Sucker. Not uncommon. July and August.

217. Remora remora (Linn.) Remora. Accidental.

\section{Family URANOSCOPIDÆ}

(Marine)

218. Astroscopus guttatus (Abbott). Spotted Stargazer. Accidental. Fall.

\section{Family BATRACHOIDID $Æ$ \\ (Marine)}

219. Opsanus tau (Linn.) Toadfish. Common. Resident.

\section{Family BLENNIIDE}

\section{(Marine)}

220. Chasmodes bosquianus (Lac.) Striped Blenny. Occasional.

221. Pholis gunnellus (Linn.) Rock Eel. Uncommon. Autumn and winter (January).

\section{Family CRYPTACANTHODIDE}

\section{(Marine)}

222. Cryptacanthodes maculatus Storer. Ghostfish Occasional.

Family ANARHICHADIDÆ

(Marine)

223. Anarhichas lupus Linn. Wolf Fish. Rare.

\section{Family ZOARCIDA}

(Marine)

224. Zoarces anguillaris (Peck). Eelpout. "Conger Eel." Resident. Abundant in fall and winter.

\section{Family OPHIDIID $\approx$}

\section{(Marine)}

225. Rissola marginata (De Kay). Slippery Dick. Occasional. October to October 30. 


\section{Family MERLUCCIID 2}

(Marine)

226. Merluccius bilinearis (Mitch.) Silver Hake. Sometimes common. Spring (May) and fall (October and November) to December 18. Occasional in summer.

\section{Family GADIDE}

(Marine, except No. 231)

227. Pollachius virens (Linn.) Pollack. Occasional. Most often in winter, sometimes summer.

228. Microgadus tomcod. (Walb.) Tomcod. Resident. Abundant in fall and early winter.

229. Gadus callarias Linn. Cod. Sometimes abundant. October to May 29 (1918, H. C. Graff). Small specimens ("Rock Cod"). Occasional in summer.

230. Melanogrammus œeglifinus Linn. Haddock. Uncommon. Winter.

231. Lota maculosa (Le Sueur). Fresh-water Ling. Accidental. (The only fresh-water species).

232. Phycis regius (Walb.) Spotted Hake. Uncommon. September to December 18.

233. Phycis tenuis (Mitch.) Boston Hake. Uncommon. April to May. September to December.

234. Phycis chuss (Walb.) Squirrel Hake. "Ling." Common. June 26 (1917, J. T. N.) October to at least December 31. Probably occurs at all seasons.

\section{Family PLEURONECTID压}

\section{(Marine)}

235. Hippoglossus hippoglossus (Linn.) Halibut. Occasional. Winter. 236. Paralichthys dentatus (Linn.) Summer Flounder. "Fluke." Common. May 7 (1918) to November 21.

237. Paralichthys lethostigmus Jordan \& Gilbert. Southern Flounder. Recorded. (Bean, Fishes of New York, Bull. N. Y. State Mus., 1903.)

238. Paralichthys oblongus (Mitch.) Four-spotted Flounder. Common in rather deep water (November).

239. Limanda ferruginea (Storer). Rusty Dab. Common in rather deep water (November).

240. Pseudopleuronectes americanus (Walb.) Winter Flounder. "Flatfish." Abundant. Resident. 
241. Lophopsetta maculata (Mitch.) Sundial. Common (Spring) August to December 18.

242. Platophrys ocellatus (Ag.) Sand Flounder. Accidental. September.

243. Etropus microstomus (Gill.) Small-mouthed Flounder. At times tolerably common. September and October.

\section{Family SOLEIDE}

(Marine)

244. Achirus fasciatus Lac. American Sole. Common. April to December.

\section{Family LOPHIIDÆ}

(Marine)

245. Lophius piscatorius Linn. Angler. "Toadfish." Common. October to May 19 (1918). A few summer.

\section{Family ANTENNARIIDE}

(Marine)

246. Histrio histrio (Linn.) Mousefish. Accidental. August. (Bean,

Art. XXIV, Bull. Am. Mus. Nat. Hist., Vol. IX, 1897, p. 329.)

Family OGCOCEPHALID $\mathbb{E}$

(Marine)

247. Ogcocephalus vespertilio (Linn.) Batfish. Accidental. Midsummer. 
Acipenseridse, 27, 101

Agonidæ, 26, 115.

Albacore, 72, 113.

Albulidæ, 28, 104.

Alewife, 46, 105.

Alopiidæ, 23, 101.

Amber Fish, 76, 112.

Amberjack (see Amber Fish).

Ammodytidæ, 25, 108.

Anarhichadidæ, 26, 116.

Anchovy, Common, 46, 105; Flat, 46, 105; Silvery, 46, 105; Striped, 46, 105.

Angelfish, Black, 83, 113.

Angler, 98, 118.

Anguillidæ, 25, 106.

Antennariidæ, 29, 118.

Aphredoderidæ, 31, 108.

Argentinidæ, 27, 106.

Atherinidæ, 30, 108.

Balistidæ, 26, 114.

Barracuda, Northern, 57, 108.

Batfish, 98, 118.

Batrachoididæ, 31, 116.

Belonidæ, 25, 107.

Bergall, 80, 113.

Bermuda Chub, 66, 110.

Big-eye, Deep, 65, 110.

Billed Eel (see Billfish).

Billfish, 53, 107.

Black Bass, Large-mouthed, 59, 109 ; Small-mouthed, 59, 109.

Blackfish, 81, 113.

Blenniidæ, 25, 31, 116.

Blenny, Striped, 89, 116.

Blob, 85, 115.

Blowfish, 84, 114.

Bluefish, 76, 111.

Bluegill, 61, 109.

Bonefish (see Ladyfish).

Bonito, 73, 113; Oceanic, 72, 112.

Boxfish, Spiny, 85, 114.

Bumper, 74, 112.

Butterfish, 79, 111.

Butterfly Fish, 82, 113;

Butterfly Ray, 37, 102.

Calico Bass, 59, 109.

Carangidæ, 29, 30, 112.

Carchariidæ, 24, 101
Carp, 42, 103

Catfish, Channel, 39; Common (see Horned Pout); Gaff-topsail, 39, 102; Mississippi, 39, 103; Mud, 38, 103; Sea, 39, 102; Spotted, 39, 103; Stone. 38, 103; White, 39, 103.

Catostomidæ, 27, 103.

Cephalacanthidæ, 29, 115

Cetorhinidæ, 24, 101.

Chætodontidæ, 31, 113

Channel Bass, 69, 111

Clupeidæ, 28, 104.

Cod, 92, 117.

Conger Eel, 91, 116.

Coryphænidæ, 29, 111

Cottidæ, 29, 115.

Cow-nosed Ray, 37, 102

Crab-eater, 78, 111.

Crappie, 59, 109.

Croaker, 70, 111; Banded, 69, 111

Cryptacanthodidæ, 25, 116.

Cunner, 81.

Cutlass Fish, 73, 113.

Cyclopteridæ, 27, 115.

Cyprinidæ, 28, 103.

Dab, Rusty, 95, 117.

Dace, Black-nosed, 40, 104; Horned, 43, 103; Long-nosed, 41, 104; Rosy, 43, 103.

Darter, Fusiform, 63, 109; Johnny, 63, 109.

Dasyatidæ, 24, 102.

Daylight (see Sundial).

Diodontidæ, 26, 114.

Doctorfish, 83, 113.

Dogfish, Smooth, 33, 100; Spined, 35, 101.

Dolphin, Common, 78, 111

Dorosomidæ, 28, 104.

Drum, 70, 111.

Echineididæ, 26, 116.

Eel, Common, 49, 106; Conger, 49, 91, 106; Sea, 106.

Eelpout, 91, 116.

Elopidæ, 28, 104.

Engralididæ, 28, 105

Ephippidæ, 31, 113.

Esocidæ, 28, 106. 
Eucinostomidæ, 32, 110.

Exocœetidæ, 27, 107.

Fallfish, 43, 103.

Filefish, 84, 114; Orange, 84, 114; Unicorn, 84, 114.

Fistulariidæ, 25, 107

Flatfish, 95, 117.

Flounder, Four-spotted, 97, 117; Sand, 97, 118; Small-mouthed, 97, 118; Southern, 96, 117; Summer, 96, 117; Winter, $95,117$.

Fluke, 96, 117.

Flying Fish, 54, 107; Bearded, 54, 107; Double-bearded, 54, 107.

Flying Gurnard, 88, 115

Frostfish, 94.

Gadidæ, 32, 117.

Galeidæ, 24, 100.

Gar, Long-nosed, 38, 102.

Gascon, 73, 112.

Gasterosteidæ, 29, 107.

Ghostfish, 90, 116.

Gizzard Shad, 45, 104.

Goatfish, 57, 108.

Gobiidæ, 31, 115.

Goby, Naked, 88, 115.

Golden Ide, 42, 103.

Goldfish, 42, 103.

Hacklehead, 86, 115.

Haddock, 92, 117.

Haemulidæ, 32, 110.

Hake, Boston, 93, 117; Silver, 92, 117; Spotted, 93, 117; . Squirrel, 93, 117.

Halfbeak, 53, 107.

Halibut, 95, 117.

Hardtail, 74, 112.

Harvest Fish, 79, 111

Headfish, 85, 114.

Hemiramphidæ, 25, 107.

Herring, 45, 104; Big-eyed, 45. 104; Glut, 46, 105; Round, 45, 104; Thread, 45, 105.

Hickory Shad, 46, 104.

Hog-choker (see Sole).

Horned Pout, 39, 103.

Hornyhead, 43, 104.

Ide, Golden, 42, 103.

Istiophoridæ, 25, 113.
Jackfish, 74, 112.

Killy, Bass, 52, 106; Common (see Mummichog); Fresh-Water, 52, 106;

Lucy's, 52, 106.

Kingfish, 70, 111.

Kyphosidæ, 31, 110 .

Labridx, 31, 113.

Ladyfish, 45, 104.

Lafayette, 69, 111.

Lamnidæ, 24, 101.

Lamprey, Brook, 49, 100; Sea, 49, 100.

Leatherjacket, 75, 112.

Lepisosteidæ, 24, 102.

Leptocephalidx, 25, 106.

Ling, 93, 117; Fresh-water, 94, 117.

Lizard Fish, 48, 106.

Lobotidæ, 32, 110.

Lookdown, 74, 112.

Lophiidæ, 29, 118.

Lumpfish, 87, 115.

Lutianidæ, 32, 110.

Mackerel, 71, 112; Chub, 71, 112; Spanish, 72, 113.

Menhaden, 45, 105.

Merlucciidæ, 32, 117.

Micropteridæ, 32, 109.

Miller's Thumb, 85.

Minnow, Abbott's, 44, 104; Black-nosed 41; Blunt-nosed, 43, 103; Bridled, 44, 104; Cut-Lip, 40, 104; Delaware, 44, 104; Mud, 51, 106; Raritan, 44, 104; Sheepshead, 51, 106; Silvery, 43, 103.

Mojarra, 66, 110.

Molidæ, 26, 114.

Monacanthidæ, 26, 114.

Monkfish, 35, 102.

Moonfish, 74, 112.

Mossbunker, 105.

Mousefish, 98, 118.

Mud Minnow, 51, 106.

Mugilidæ, 30, 108.

Mullet, Common, 56; Striped, 56, 108;

White, 57, 108.

Mullidæ, 28, 108.

Mummichog, 52, 106.

Myliobatidæ, 24, 102.

Narcobatidæ, 24, 102.

Nibbler, 81. 
Ogcocephalida, 25, 118.

Ophidiidæ, 25, 116.

Ostraciidæ, 26, 114.

Pearl Roach, 41, 103.

Perch, White, 64, 109; Yellow, 61, 109.

Percidse, 30, 109.

Petromyzonidæ, 23, 100.

Pickerel, Banded, 50, 106; Chained, 50, 106.

Pigfish, 66, 110.

Pike, 50, 106.

Pike Perch, 63, 109.

Pilotfish, 76.

Pinfish (see Sailor's Choice).

Pipefish, 55, 107.

Pirate Perch, 58, 108.

Pleuronectidæ, 26, 117.

Pœciliidæ, 28, 106.

Pollack, 92, 117.

Polynemidæ, 28, 108.

Pomatomidæ, 30, 111.

Pompano, Common, 76, 112; Round, 76. 112.

Porgy, 67, 110.

Priacanthidæ, 32, 110.

Rachycentridæ, 30, 111.

Rain-water Fish, 52, 106.

Rajidæ, 24, 102.

Redfin, 44, 104.

Red Horse, 40, 103.

Remora, 88, 116.

Rock Bass, 60, 109.

Rock Cod, 117.

Rock Eel, 90, 116.

Rosefish, 87, 114.

Rudd, 41.

Rudderfish, 79, 111; Banded, 76, 112

Runner, 75, 112.

Rusty Dab, 95, 117.

Saibling, 47, 105.

Sailfish, 73, 113.

Sailor's Choice, 67, 110.

Salmon, Atlantic, 47, 105; Landlocked; 47, 105.

Salmonidæ, 27, 105.

Sand Eel, 58, 108.

Scabbard Fish, 113.

Scad, 73. 112; Goggle-eyed, 74, 112.

Sciænidæ, 30, 31, 110.

Scombridæ, 29, 112.
Scorprenidxe, 29, 114

Sculpin, Brassy, 85, 115; Daddy, 86, 115; Eighteen-spined (see Hacklehead); Mitchill's, 85, 115.

Sea Bass, 64, 109. Sea Horse, 55, 107 ;

Poacher, 87, 115; Raven, 86, 115; Robin, Carolina, 87, 115; Striped, 88, 115.

Serranidæ, 30, 32, 109.

Shad, 46, 105; Gizzard, 45, 104; Hickory, $46,104$.

Shark, Basking, 35, 101; Blue, 33, 100; Brown, 33, 101; Cub, 33, 101; Dusky, 33, 101; Edged, 33, 101; Hammerhead, 34, 101; Mackerel, 34, 101; Man-eater, 34, 101; Sand, 34, 101; Thresher, 34, 101; Tiger, 34, 100; White, 34, 101.

Shark Sucker, 88, 116.

Sheepshead, 66, 110.

Sheepshead Minnow, 51, 106.

Shiner, Golden, 41, 103; Gold-thread, 43, 103.

Siluridæ, 37, 102.

Silver Hake, 92, 117.

Silver Perch, 69, 111.

Silverfin, 44, 104.

Silverside, Common, 56, 108; Freshwater, 56, 108; Rough, 56, 108.

Skate, Barn-door, 35, 102; Big, 35, 102; Clear-nosed, 35, 102; Common, 35, 102.

Skipjack (see Bonito).

Slippery Dick, 91, 116.

Smelt, 48, 106.

Snapper, 77, 111; Red, 66, 110.

Sole, American, 95, 118.

Soleidæ, 26, 118.

Spadefish, 82, 113.

Sparidæ, 32, 110.

Spawn-eater, 43.

Spearing (see Silverside, Common).

Sphyræenidæ, 30, 108.

Sphyrnidæ, 23, 101.

Spot, 69, 111.

Squalidæ, 23, 101.

Squatinidæ, 24, 102.

Stargazer, Spotted, 89, 116.

Stickleback, Four-spined, 54, 107; Tenspined, 54, 107; Two-spined, 54, 107. 
Sting Ray, Common, 37, 102.

Striped Bass, 63, 109.

Stromateidæ, 28, 30, 111.

Sturgeon, Common, 37, 102; Shortnosed, 37, 102.

Sucker, Chub, 40, 103; Shark, 88, 116; White, 40, 103.

Sundial, 97, 118.

Sunfish, Black-banded, 60, 109; Bluegill (see Blue-gill); Common, 61, 109; Holbrook's, 60, 109; Long-eared, 61, 109; Mud, 60, 109; Sea, 85; Spottedfin, 60, 109.

Swellfish, 84, 114; Smooth, 85, 114.

Swordfish, 73, 113.

Syngnathidæ, 25, 107.

Synodontidæ, 27, 106.

Tarpon, 44, 104.

Tautog, 81, 113.

- Tench, 42, 103.

Tetraodontidæ, 26, 114

Teuthididæ, 31, 113.

Threadfin, 57, 108.

Threadfish, 75, 112.

Toadfish, 89, 98, 116, 118 .
Tomcod, 93, 117.

Torpedo, 36, 102.

Trichiuridæ, 26, 113.

Triggerfish, 83, 114.

Triglidæ, 29, 115.

Triple-tail, 65, 110.

Trout, Brook, 47, 105; Brown, 47, 105; Golden (see Saibling); Rainbow, 47. 105.

Trumpet Fish, 55, 107.

Trunkfish, 84, 114.

Tuna (see Tunny).

Tunny, 72, 112; Little, 72, 112.

Umbridæ, 28, 106.

Unicorn Fish (see Filefish).

Uranoscopidæ, 29, 116.

Weakfish, 68, 110.

Whitebait, 56.

White Bass, 64, 109.

Whiting (see Silver Hake).

Wolf Fish, 90, 116.

Wreckfish, 65, 109.

Xiphiidæ, 25, 113.

Zoarcidæ, 25, 116 




IIUIIIIIIII) LBRARY

|||||||||||||||||||||||||||||||||||||||||

100008953

ХગОТОХНЦНОI 